\title{
1 Mechanisms of cadmium accumulation in plants
}

2 Thibault Sterckeman ${ }^{\mathrm{a}}$, Sébastien Thomine ${ }^{\mathrm{b}}$

3 a Université de Lorraine, Inra, Laboratoire Sols et Environnement, F-54000 Nancy, France

$4{ }^{b}$ Institute for Integrative Biology of the Cell (I2BC), CEA, CNRS, Univ. Paris-Sud, Université

5 Paris-Saclay, 91198, Gif-sur-Yvette cedex, France

6

7 Corresponding author: Thibault Sterckeman

8 ORCID: 0000-0001-5323-890X

9 ResearcherID: A-6189-2014

10 ResearchGate: https://www.researchgate.net/profile/Thibault_Sterckeman

11 E-mail: Thibault.Sterckeman@univ-lorraine.fr

12

13 Information concerning Sebastien Thomine

14 ORCID: 0000-0003-0045-1701

15 ResearcherID: V-9029-2019

16 E-mail: Sebastien.THOMINE@i2bc.paris-saclay.fr 


\section{Mechanisms of cadmium accumulation in plants}

\section{Abstract}

Cadmium is a non-essential trace metal, which is highly toxic to nearly all living organisms.

Soil pollution causes $\mathrm{Cd}$ contamination of crops, thereby rendering plant products responsible for the chronic low level Cd over-exposure of numerous populations in the world. For this reason, $\mathrm{Cd}$ accumulation in plants has been studied for about five decades now. The research first focused on the relationships between plant and soil Cd levels, on the factors of the metal availability in soil, as well as the root uptake processes. Cd distribution in plant organs was also investigated, first using a macroscopic and eco-physiological approach, then with the help of molecular biology tools, at both tissue and cell scale. Cadmium has no biological function and hijacks the transport pathways of micronutrients such as $\mathrm{Fe}, \mathrm{Mn}$ or $\mathrm{Zn}$, in order to enter the plant through the roots and be distributed to all its organs. The study of the genes that control the influx and efflux of the $\mathrm{Cd}^{2+}$ ion in the cytosol, vacuoles and vascular tissues has significantly contributed to the understanding of the metal root uptake and of its transfer to the aerial parts. However, the mechanisms responsible for its distribution to the different aboveground tissues and specially to fruits and seeds have yet to be clarified. This review summarizes current knowledge in order to present a detailed overview of $\mathrm{Cd}$ transport and storage, from the rhizosphere to the different organs and tissues of the plant.

\section{Keywords}

Ion transporter; cell wall; chelation; phytochelatin; vacuolar sequestration; xylem sap; phloem; inter-element competition; speciation; organic acid; zinc; iron; silicon; manganese; nitrogen 
41 Cadmium is a transition metal considered as a trace element by geochemists, as its

concentration in the upper continental crust - around $0.1 \mathrm{mg} \mathrm{kg}^{-1}$ - is well below the limit between trace and major elements $\left(1000 \mathrm{mg} \mathrm{kg}^{-1}\right)$. Cadmium has no known biological

function in any organism, except for the marine diatom Thalassiosira weissflogii, in which it can replace zinc as cofactor of carbonic anhydrase (Lane et al., 2005). On the contrary, Cd is highly toxic to most living organisms. The metal exerts its toxic effects by competing with essential metals and calcium, as well as inducing oxidative stress through perturbation of the glutathione redox balance. When internalized, it is retained with a biological half-life $>30$ years in the human body. It accumulates in kidneys and bones and can cause osteoporosis, kidney failure, heart disease and cancer (EFSA, 2012). This makes low-level chronic Cd exposure a serious threat to human health. This is the reason why $\mathrm{Cd}$ use has been severely limited by the European REACH regulation (http://ec.europa.eu/growth/sectors/chemicals/reach_en).

Apart from tobacco smoking, food is the main source of human exposure to $\mathrm{Cd}$, through cereals, vegetables, roots and tubers (EFSA, 2012). In these plant products, Cd comes from the soil, through root absorption and translocation to the harvested organs. Most of the soil Cd originates from contamination resulting from human activities. The sources of contamination are atmospheric deposition of industrial and urban emissions, phosphate fertilizers, organic and mineral amendments. In Europe, as atmospheric deposition has decreased since the mid1960s, Cd from P fertilizer is now the major input into cultivated soils (Six and Smolders, 2014; Sterckeman et al., 2018). The dominant form of the metal in soil is $\mathrm{Cd}^{2+}$. The physicochemical properties of this ion lead to its accumulation in the soil's ploughed layer by binding to soil solid components. However, this binding is largely reversible (Smolders et al., 1999), making $\mathrm{Cd}$ one of most available trace metals for root absorption after desorption into the soil solution (Lin et al., 2016b). 
Based on the weekly intake limit recommended by the US Agency for Toxic Substances and Disease Registry (ATSDR, 2012) of $0.7 \mu \mathrm{g}$ Cd per kg of body weight per week, most populations of the world would be largely overexposed to this metal through low-level chronic exposure due to food consumption (Clemens et al., 2013). Considering the threshold set by the European Food Safety Authority (EFSA, 2012), which is over 3 fold higher than the

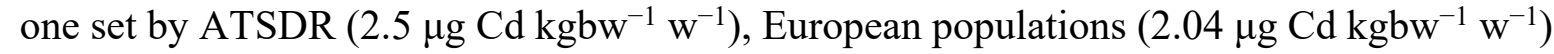
are on average just below the limit, with some of them being overexposed.

Cadmium chemistry in soil and its accumulation in plants have been studied since the seventies (e.g. (Lagerwerff, 1971; John et al., 1972; Haghiri, 1973). The aim of the investigations carried out until now has been to understand the soil supply of Cd to roots as well as the distribution, the toxicity and the tolerance of the metal in the plant organs. Several works have shown that $\mathrm{Cd}$ distribution in the plant varies greatly both from one species to another and within a given species, depending on the population or the cultivar (Florijn and Van Beusichem, 1993b; Greger and Lofstedt, 2004; Gonneau et al., 2014; Laporte et al., 2015). This highlights the importance of genetic factors in this distribution. Over the two last decades, numerous publications have addressed the biomolecular processes of $\mathrm{Cd}$ accumulation in plants, with a particular effort being made to identify the genes and related proteins responsible for Cd uptake, transport, storage and detoxification in plant tissues.

An underlying application of these works is the creation of cultivars that accumulate less $\mathrm{Cd}$ in their consumed parts (Clemens et al., 2013). Another one is the decontamination of soils by phytoextraction, i.e. the cultivation of plants accumulating high levels of $\mathrm{Cd}$ in their aerial parts, to the point that they would significantly decrease the soil's Cd content. Phytoextraction has been considered with low $\mathrm{Cd}$ accumulating and high biomass producing species, such as sunflower (Helianthus annuus), maize (Zea mays), poplar or willow. An alternative is the use of species which hyperaccumulate and are hypertolerant to metals such as $\mathrm{Cd}$, $\mathrm{Ni}$ or $\mathrm{Zn}$ 
91 (Chaney et al., 2014; Sterckeman and Puschenreiter, 2018). These wild plants are rare and peculiar, as they are able to grow on metalliferous soils that are toxic to most other species. For this reason, they have been studied extensively to the point of becoming experimental models (Cobbett, 2003; Verbruggen et al., 2009b; Honjo and Kudoh, 2019). These include Arabidopsis halleri, Noccaea caerulescens (Brassicaceae) or Sedum alfredii (Crassulaceae).

We have written this review bearing in mind these underlying applications, which both require an in-depth understanding of the mechanisms controlling Cd flow from soil to plant, in order to be able to either reduce the Cd content in the consumed parts (grain, tubers, leaves) or increase it in the harvested shoots of the plant used to decontaminate the soils. This review thus focuses both on the processes responsible for the transfer of $\mathrm{Cd}$ from soil to plant and on those responsible for the distribution of the metal in the different plant parts under non-toxic conditions. The mechanisms of Cd toxicity and tolerance are not addressed as such in this review, but only with regards to their possible contribution to the flow and the distribution of the metal in the plant. For instance, Cd sequestration in cell walls and in vacuoles is a way to reduce $\mathrm{Cd}$ toxicity in plants, but it will be regarded here more as a factor controlling $\mathrm{Cd}$ distribution and storage among tissues and organs. The reader may refer to other literature reviews regarding the management of Cd toxicity by plants (Moulis, 2010; Lin and Aarts, 2012; Verbruggen et al., 2013; Choppala et al., 2014; Kupper and Andresen, 2016).

\section{Overview of the plant $\mathrm{Cd}$ accumulation processes}

Cadmium exists mainly in the soil as the divalent cation $\mathrm{Cd}^{2+}$. Cadmium concentration as free hydrated ions in soil solutions is in equilibrium with dissolved $\mathrm{Cd}$ complexes and $\mathrm{Cd}$ adsorbed onto the soil solid phase. By the means of proton excretion, root cells maintain a negative gradient across their plasma membrane, which drives cation absorption, including that of $\mathrm{Cd}^{2+}$. The absorption of $\mathrm{Cd}^{2+}$ by root cells reduces the ion concentration at the root 
115 surface, generating a concentration gradient, which in turn drives diffusion of $\mathrm{Cd}^{2+}$ towards

116 the root. Cadmium is also transported by advection, where the ion moves towards the root at

117 the same speed as the water taken up by the plant for transpiration. However, in the case of

$118 \mathrm{Cd}$, advection is most frequently negligible when compared to diffusion. In addition, $\mathrm{Cd}^{2+}$

119 desorbed from the solid phase replenishes the soil solution as the root depletes it (Figure 1).

120 Some of the Cd ions in the solution adsorb onto the pecto-cellulosic walls of the root cells

121 (root apoplast). Others diffuse through the apoplast until they meet the first apoplastic barrier,

122 i.e. a domain of the extracellular matrix that prevents the diffusion of ions between cells due

123 to deposits of impermeable polymers such as lignin (Casparian strip) or suberin. Depending

124 on the plant species or on the location along the root, the first apoplastic barrier is the

125 exodermis, located just below the root absorptive epidermis in rice for example, or

126 endodermis, delimiting the central cylinder where the root vasculature is located (Figures 2-

127 4). From the apoplast, the ions cross the cell membrane (plasma membrane) using the

128 transport proteins. Under a membrane potential of $-120 \mathrm{mV}$, as usually measured in root cells,

$129 \mathrm{Cd}^{2+}$ may accumulate passively by 4 orders of magnitude. Therefore, active transport is not

130 required to drive $\mathrm{Cd}^{2+}$ uptake into root cells. Once in the cytosol, $\mathrm{Cd}$ ions are complexed by

131 organic ligands. This reduces the concentration of free $\mathrm{Cd}^{2+}$ in the cytosol and therefore the

132 metal toxicity. Some of the $\mathrm{Cd}$ in the cytosol diffuses towards the xylem, following the

133 plasmodesmata to pass from one cell to another to reach the xylem parenchyma (Figures 2-4).

134 The metal can then be loaded into the xylem vessels by the way of an active transport system,

135 against its electrochemical gradient. Other Cd compounds in the cytosol are distributed to

136 intracellular organelles such as the mitochondria, the Golgi apparatus and mainly the vacuole,

137 through transport proteins. In the vacuole lumen, $\mathrm{Cd}$ is mostly chelated by organic ligands.

138 It can therefore be considered that once $\mathrm{Cd}^{2+}$ is absorbed into the root symplast, its

139 translocation to the aerial parts is governed by three main processes: sequestration in the root 
cells, transport in the symplast to the stele and xylem loading. The competition between these three processes leads most higher plants to accumulate much more $\mathrm{Cd}$ in their roots than in their shoots. Nonetheless, some species, such as hyperaccumulating plants, accumulate a higher concentration of the metal in their above ground parts than in their roots.

Once in the xylem sap, $\mathrm{Cd}^{2+}$ eventually forms complexes with ligands. These complexes, together with free ions, are transported to the plant aerial parts with the xylem sap flow being driven by transpiration (advection). During this transport, the ions interact with the cell walls of xylem vessels and partly adsorb on them. They also migrate through xylem cell walls to those of the stem and leave cells, under the influence of the transpiration flow. From the apoplast, $\mathrm{Cd}^{2+}$ crosses cell membranes via transport proteins (Figure 5). Once in the leaf cell cytosol, the metal is generally chelated by organic ligands and migrates from cell to cell. Some of the free ions and of the complexes enter the organelles and particularly the vacuole, where they are stored as chelates. In the shoot, $\mathrm{Cd}^{2+}$ is finally distributed in variable amounts according to the cell compartment (wall, cytosol, vacuoles, etc.) and to the tissue (vascular tissues, parenchyma, epidermis...), with a speciation differing with the location and with the plant species.

Although less documented, it is likely that part of the Cd accumulated in the leaves is redistributed to other plant organs via the phloem, or even to the roots where Cd could be excreted. The phloem flow also allows Cd transport to the reproductive organs and its accumulation in the seeds. Some works suggest that phloem could be involved in Cd transport before it reaches the leaves, thanks to exchanges from xylem to phloem in the stem.

\section{Chemistry of $\mathrm{Cd}$ in the rhizosphere}

Plant roots take up $\mathrm{Cd}$ from the surrounding soil solution. The chemistry of $\mathrm{Cd}$ in the rhizosphere can usefully be considered as the reactions that control the species and the 
concentrations of the metal in solution. These reactions take place in the soil solution and at the surface of the solid phase (Figure 1). With an ionic potential $(I P=\mathrm{Z} / \mathrm{r}$, the valence divided by the ionic radius in $\mathrm{nm}$ ) of $21 \mathrm{~nm}^{-1}, \mathrm{Cd}^{2+}$ is a solvating cation, whose behaviour can be differentiated from that of hydrolysing cations, such as $\mathrm{Al}^{3+}\left(I P=56 \mathrm{~nm}^{-1}\right)$, and oxyanionforming cations, such as $\mathrm{Mo}^{6+}\left(I P=143 \mathrm{~nm}^{-1}\right)$ (Sposito, 1989). Based on this parameter, $\mathrm{Cd}^{2+}$ behaves similarly to $\mathrm{Ca}^{2+}\left(I P=20 \mathrm{~nm}^{-1}\right)$. However, it is differentiated from this cation by its Misono softness parameter $(Y, \mathrm{~nm}$ ), whose value is $0.31 \mathrm{~nm}$ (Misono et al., 1967; Sposito, 1989). Values of $Y$ above $0.32 \mathrm{~nm}$ correspond to metal ions with high polarizability and low electronegativity, which tend to form covalent chemical bonds, while values below $0.25 \mathrm{~nm}$ correspond to ions with low polarizability and high electronegativity tending to form ionic bonds. Cadmium, together with $\mathrm{Cu}^{2+}, \mathrm{Mn}^{2+}, \mathrm{Ni}^{2+}$ and $\mathrm{Fe}^{2+}$ fall into the "borderline" zone $(0.25<Y<0.32)$, while $\mathrm{Ca}^{2+}$ has a $Y$ value of $0.16 \mathrm{~nm}$ and $\mathrm{Hg}$ and $\mathrm{Pb}$ have $\mathrm{Y}$ values of 0.40 $\mathrm{nm}$. This makes $\mathrm{Cd}^{2+}$ chemical behaviour intermediate between that of $\mathrm{Ca}^{2+}$, forming ionic bonds, and those of $\mathrm{Pb}^{2+}$ and $\mathrm{Hg}^{2+}$, often involved in covalent bonds.

In the solution of non- or low contaminated soils, $\mathrm{Cd}$ concentration is generally below $10 \mathrm{nM}$, while in Cd polluted soils, it ranges between $10 \mathrm{nM}$ to $200 \mathrm{nM}$, and can even reach micromolar concentrations under extreme contamination and solubility conditions (Helmke, 1999; Sauvé et al., 2000b; Weng et al., 2002; Nolan et al., 2003; Maxted et al., 2007). The free hydrated ion $\left(\mathrm{Cd}^{2+}\right)$ is in equilibrium with organic and inorganic complexes. $\mathrm{Cd}^{2+}$ reacts with water to form $\mathrm{Cd}(\mathrm{OH})_{2}, \mathrm{Cd}(\mathrm{OH})^{+}$and $\mathrm{Cd}(\mathrm{OH})_{3}{ }^{-}(\mathrm{Gu}$ et al., 2010). In the presence of chloride, particularly in salt affected soils, $\mathrm{Cd}^{2+}$ can form soluble chloride complexes, i.e. $\mathrm{CdCl}^{+}, \mathrm{CdCl}_{2}, \mathrm{CdCl}_{3}{ }^{-}$and $\mathrm{CdCl}_{4}{ }^{2-}$. $\mathrm{Cd}^{2+}$ reacts with sulphate, to form $\mathrm{CdSO}_{4}$ complexes and, in alkaline soil, with carbon dioxide to form $\mathrm{CdCO}_{3}$ and $\mathrm{CdHCO}_{3}{ }^{+}$in solution (Alloway, 1995; Helmke, 1999). Free $\mathrm{Cd}^{2+}$ is considered to dominate in soil solutions (Degryse et al., 2009; Ren et al., 2015a), although some measurements and modelling have shown that this is 
not always the case (Schneider, 2008; Lin et al., 2016b). Indeed, the free hydrated ion can associate to a large extent with soluble humic compounds (Schneider, 2008; Ren et al., 2015a; Ren et al., 2015b), as well as with well-defined molecules such as organic acids (Schneider and Nguyen, 2011). For instance, Lackovic et al. (2004) proposed several reactions to model Cd complexation by citrate (noted L):

$\mathrm{Cd}^{2+}+\mathrm{L}^{3-}+\mathrm{H}^{+} \leftrightarrows \mathrm{CdLH}^{0}(\log \mathrm{K}=7.85)$

$\mathrm{Cd}^{2+}+\mathrm{L}^{3-} \leftrightarrows \mathrm{CdL}^{-}(\log \mathrm{K}=3.71)$

$\mathrm{Cd}^{2+}+2 \mathrm{~L}^{3-} \leftrightarrows \mathrm{CdL}_{2}^{4-}(\log \mathrm{K}=5.3)$

$\mathrm{Cd}^{2+}+\mathrm{L}^{3-}+\mathrm{H}_{2} \mathrm{O} \leftrightarrows \mathrm{CdOHL}^{2-}+\mathrm{H}^{+}(\log \mathrm{K}=-3.4)$

Cadmium competes with other cations, such as $\mathrm{Ca}^{2+}$ for complexation with soluble organic ligands (Lin et al., 2016b).

In most soils, the amount of dissolved $\mathrm{Cd}$ is much lower than that bound to the solid phase. Cadmium can precipitate as carbonate or phosphate, but soils are generally under-saturated with these minerals (Tye et al., 2003). Even if super-saturated, dissolved organic matter has been reported to inhibit $\mathrm{CdCO}_{3}$ precipitation (Holm et al., 1996). Therefore, rather than precipitation, adsorption on mineral surfaces and binding to humic substances are the processes which control Cd partitioning between solid and liquid phases (Lofts and Tipping, 1998; Tipping, 1998; Ren et al., 2015b). Indeed, Cd can bind with particulate fulvic or humic acid $(\mathrm{R})$ with a net charge $\mathrm{Z}$, exchanging against protons according to the following equation:

$\mathrm{RH}^{\mathrm{Z}}+\mathrm{Cd}^{2+} \leftrightarrows \mathrm{RCd}^{\mathrm{Z}-1+2}+\mathrm{H}^{+}$

The metal also interacts with the surface sites on minerals, particularly on Fe and $\mathrm{Mn}$ hydroxides and clay minerals. Surface complexation reactions on variable charged sites 
$(\equiv \mathrm{SOH})$, such as those at the edges of clay minerals or of iron hydroxides can be formalized

212 by:

$213 \equiv \mathrm{SOH}^{0}+\mathrm{Cd}^{2+} \leftrightarrows \equiv \mathrm{SOCd}^{+}+\mathrm{H}^{+}[\log \mathrm{K}=-3.23$ for kaolinite, (Gu and Evans, 2008) $]$

214 while adsorption on permanent negatively charged sites $\left(\equiv \mathrm{X}^{-}\right)$is

$215 \equiv 2 \mathrm{X}^{-} \mathrm{H}^{+}+\mathrm{Cd}^{2+} \leftrightarrows \equiv \mathrm{X}_{2}^{-} \mathrm{Cd}^{2+}+2 \mathrm{H}^{+}[\log \mathrm{K}=1.22$ for kaolinite, (Gu and Evans, 2008)].

216 However, as the soil matrix is very complex, with numerous constituents having each

217 different types of surface reactive sites, Cd adsorption is generally modelled using the values of the distribution coefficient, $K_{d}\left(\mathrm{~L} . \mathrm{kg}^{-1}\right)$, which is the ratio of Cd reversibly adsorbed on the solid phase divided by metal in solution. $K_{d}$ ranges from several tens to several thousands (Sauvé et al., 2000a; Sauvé et al., 2000b). $K_{d}$ is generally well predicted by a function of soil organic carbon and pH (Sauvé et al., 2000a; de Meeûs et al., 2002; Degryse et al., 2009), such that

$\log \left(K_{d}\right)=-1.04+0.55 p H_{C a C l 2}+0.70 \log \left(C_{\text {org }}\right)\left(n=123, \mathrm{R}^{2}=0.72\right)$

proposed by Degryse et al. (2009), $C_{\text {org }}$ being the organic carbon content (\%) and $\mathrm{pH}_{\mathrm{CaCl2}}$ the $\mathrm{pH}$ of a soil suspension in a $0.01 \mathrm{M} \mathrm{CaCl}_{2}$ solution. This relationship supports the idea that organic carbon is the most important reactive fraction of the soil solid phase (Tye et al., 2003; Ren et al., 2015b) and that Cd sorption increases with organic carbon content of the solid phase. In addition, the solubility of $\mathrm{Cd}$ associated to Fe oxides is affected by the soil redox potential (Yu et al., 2016). Moreover, in carbonated soils, Cd can sorb at the surface of calcite, with $\mathrm{Cd}^{2+}$ replacing $\mathrm{Ca}^{2+}$. This could lead to an irreversible absorption, as $\mathrm{Cd}$ diffuses through the calcite and makes a solid solution of otavite-calcite (Martin-Garin et al., 2003). depends on the various cations in solution together with $\mathrm{Cd}^{2+}$. Eqs. 5-8 indicate that protons 
compete with $\mathrm{Cd}^{2+}$ both for adsorption on the soil minerals and for binding with humic substances phase. Various works have evidenced that $\mathrm{Cd}$ sorption increases with $\mathrm{pH}$ (Christensen, 1984; Sauvé et al., 2000a). Eq. 8 shows that sorption at $\mathrm{pH}=5.0$ is about ten times lower than at $\mathrm{pH}=7.0$. Competition with other cations, in particular with $\mathrm{Ca}^{2+}$, also inhibits Cd sorption (Christensen, 1984; Alloway, 1995).

Although mostly sorbed on the solid phase, its physico-chemical characteristics make Cd more mobile from solid to liquid and therefore more available for root absorption than most other trace metals. When applied to variably contaminated surface horizons, isotopic dilution showed that on average, $61 \%(9 \%$ to $92 \%)$ of $\mathrm{Cd}$ was isotopically exchangeable, i.e. in equilibrium with the solution content and likely to dissolve in case of the depletion of the solution (Degryse et al., 2004). In another study, it was shown that $46 \%$ of $\mathrm{Cd}$ in cultivated soils was isotopically exchangeable (Sterckeman et al., 2009).

As a consequence of its chemistry, $\mathrm{Cd}$ availability for absorption by roots increases with the soil $\mathrm{Cd}$ content and acidity, as well as with the $\mathrm{Ca}^{2+}$ in soil solution, and decreases when soil sorption capacity, in particular soil organic matter, increases (Lin et al., 2016b).

\section{Cadmium species absorbed by the roots}

Most studies suggest or consider that the main absorbed $\mathrm{Cd}$ species is $\mathrm{Cd}^{2+}$, i.e. the free ion (Welch and Norvell, 1999). Custos et al. (2014) showed that when reducing the concentration of $\mathrm{Cd}^{2+}$ in nutrient solution by chelating it by EDTA, the absorption of the metal by maize in hydroponics was strongly decreased. However, Cd complexes (or chelates) can contribute to root uptake in two ways. Firstly, it has been reported that organo-metallic complexes can dissociate in the vicinity of the root surface, as the solution is depleted in free ions due to absorption by the root (Degryse et al., 2006; Panfili et al., 2009; Wang et al., 2009). Therefore, the pool of complexed Cd contributes to the buffering of the free $\mathrm{Cd}$ pool. 
258 However, this contribution was shown to be very small. Through modelling, Lin et al.

259 (2016b) estimated that in most cases, the dissociation of Cd complexes is slower than

260 desorption from the solid phase and not fast enough to supply the roots with $\mathrm{Cd}^{2+}$.

261 The other contribution of the complexed Cd would be through direct absorption. However,

262 this seems variable according to the experimental conditions and has never been directly

263 demonstrated. According to Panfili et al. (2009), durum wheat (Triticum turgidum L. ssp.

264 durum) is not able to absorb Cd-citrate complexes, in opposition to what Berkelaar and Hale

265 (2003a, 2003b) suggested. However, different experiments have shown the presence of Cd-,

$266 \mathrm{~Pb}$ - and $\mathrm{Zn}$-EDTA complexes in plant tissues, suggesting that they may be absorbed by roots

267 (Sarret et al., 2001; Collins et al., 2002; Schaider et al., 2006). The uptake of Cd by maize in

268 hydroponics being greater than that predicted by a model based on the sole absorption of

$269 \mathrm{Cd}^{2+}$, Custos et al. (2014) also suggested that Cd-EDTA was absorbed from the nutrient

270 solution. Blaylock et al. (1997) showed that an addition of EDTA and other

271 aminopolycarboxylates like EGTA or DTPA to soil, increases the accumulation of Cd in

272 Indian mustard, although it is not excluded that this could be the consequence of the

273 damaging of the endodermis by the chelates (Nowack et al., 2006). Cadmium complexes

274 would enter the plant through the apoplast at sites lacking apoplastic barriers, i.e. at the root

275 apex (Redjala et al., 2011) and at the emergence of lateral roots. The driver of the complex

276 uptake would be the water flow caused by the plant transpiration (Nowack et al., 2006; Custos

277 et al., 2014), although it is not clear how the complexes would cross cell membranes.

278 Some studies have shown a positive effect of chloride on Cd uptake, in both soil and

279 hydroponics (Smolders and McLaughlin, 1996a, 1996b; McLaughlin et al., 1997; Weggler et

280 al., 2004). Two mechanisms could account for this effect: (i) the formation of $\mathrm{CdCl}_{\mathrm{n}}^{2-\mathrm{n}}$

281 complexes could favour the desorption of the metal from the soil solid phase, (ii) the

282 complexes $\left(\mathrm{CdCl}_{n}^{2-n}\right)$ could diffuse faster than the free ion in the rhizosphere or in the 
apoplast. Absorption of the complexes themselves is not excluded, as $\mathrm{CdCl}^{+}$could cross the plasma membrane through selective ion channels for monovalent cations such as $\mathrm{K}^{+}$. In addition, the neutral form $\mathrm{CdCl}_{2}^{0}$ could passively cross the lipid bilayer (Welch and Norvell, 1999).

Analogous effects, but less intense than with $\mathrm{Cl}^{-}$, have been obtained with $\mathrm{SO}_{4}^{2-}$. The $\mathrm{Cd}$ concentration in the soil solution increases upon addition of sulphate, which slightly increases Cd absorption (McLaughlin et al., 1998b). An experiment in hydroponics suggests that the $\mathrm{CdSO}_{4}^{0}$ complex is taken up by plants as efficiently as free $\mathrm{Cd}^{2+}$ ion (McLaughlin et al., 1998a). The electrically neutral $\mathrm{CdSO}_{4}^{0}$ complex would passively diffuse across the plasma membrane.

\section{Influence of the plant on soil Cd availability}

In theory, roots can influence the concentration and speciation of $\mathrm{Cd}$ in the rhizosphere and consequently their ability to take up the metal. Indeed, according to the charge balance resulting from the absorption of the nutritive ions, the roots compensate the imbalance by excreting protons $\left(\mathrm{H}^{+}\right)$or hydroxyls $\left(\mathrm{OH}^{-}\right)$(Hinsinger et al., 2003). In the first case, the rhizosphere acidification would favour the desorption of $\mathrm{Cd}^{2+}$ from the soil solid phase while in the second, the alkalization would increase the sorption of the metal (Eq. 8). Acidification of the rhizosphere should therefore increase root $\mathrm{Cd}$ uptake, in contrast to alkalization. However, this effect could only rarely be demonstrated in the case of $\mathrm{Cd}$. Wu (1989) found that nitrogen fertilization of ryegrass using $\mathrm{NH}_{4}^{+}$increased plant $\mathrm{Cd}$ uptake, compared with fertilization using nitrate. He attributed this observation to the increase in soil acidity following the higher proton release by the roots absorbing ammonium.

The excretion of organic ligands such as organic acids (Jones et al., 2009) or phytosiderophores could also cause changes in Cd availability in the rhizosphere. Using 
isotopic dilution, Sterckeman et al. (2005) found an increase in the availability of Cd in the rhizosphere (measured by $L$ value) compared to bulk soil (represented by the $E$ value). This was the case in an alkaline soil but not in a slightly acidic one. In the alkaline soil, the pool of isotopically exchangeable $\mathrm{Cd}$ (i.e. $\mathrm{Cd}$ in solution and on the solid phase in equilibrium with that in solution) was greater in the rhizosphere than that in the bulk soil. Some reactions, due to changes in the chemical composition of the rhizosphere soil might therefore have modified the Cd speciation. However, these reactions as well as their origin (roots or associated microflora) are unknown. The increase in Cd availability varied according to the six plant species tested. It was maximal for ryegrass and nil for the hyperaccumulator $N$. caerulescens, in agreement with the results reported by Hutchinson et al. (2000) and Zhao et al. (2001) who also showed that root exudates of $N$. caerulescens did not increase desorption of $\mathrm{Cd}$ and $\mathrm{Zn}$.

Organic acids can increase the solubility of soil $\mathrm{Cd}$, displacing ions adsorbed on the solid phase into the solution as they complex the dissolved free ions (Naidu and Harter, 1998). Whether they favour Cd uptake (Cieslinski et al., 1998) or decrease it through the formation of Cd complexes which are not absorbable by the roots (Pinto et al., 2008) is a matter of debate (as discussed above). Oxalate excreted by tomato roots in response to Cd exposure has been shown to reduce the metal toxicity, probably because $\mathrm{Cd}$ oxalate complexes are excluded from the roots (Zhu et al., 2011). In contrast, Tao et al. (2015) suggested that the strong excretion of oxalate at the root apex of the Cd hyperaccumulating accession of $S$. alfredii may favour $\mathrm{Cd}$ uptake and accumulation. The mechanisms underlying this observation are however, not clearly identified. They could involve the dissociation of the complex at the root surface, a direct uptake of the chelate through specific transport systems or an apoplastic absorption of the chelates.

Phytosiderophores, such as mugineic and deoxy mugineic acids (MA, DMA), are ironcomplexing agents synthetized from nicotianamine and secreted by grasses suffering from a 
332 Fe deficiency (Shojima et al., 1990). Experiments with rice (Oryza sativa) and maize suggest 333 that phytosiderophores may favour the availability and uptake of Zn (Zhang et al., 1989; von

334 Wirén et al., 1996; Arnold et al., 2010; Ptashnyk et al., 2011). However, their effect on Cd uptake has not been completely clarified. Puschenreiter et al. (2017) observed enhanced Zn,

$\mathrm{Cu}, \mathrm{Mn}$ and $\mathrm{Ni}$ concentrations in wheat shoots on some soils associated with phytosiderophore exudation in Fe-deficient wheat (Triticum aestivum). However, plant Cd concentration did not increase. Accordingly, an addition of DMA to a soil suspension did not increase the Cd concentration in the solution. In contrast, the work of Shenker et al. (2001) indicated that phytosiderophores are able to increase $\mathrm{Cd}$ desorption from the soil solid phase. However, as in the work of Puschenreiter et al. (2017), they did not cause an increase in metal uptake by wheat or barley (Hordeum vulgare). With maize cultivated in hydroponics, Hill et al. (2002) showed that Cd stress, as with Fe deficiency, causes greater DMA production by roots, while DMA appears to limit $\mathrm{Cd}$ accumulation. These results suggest that phytosiderophores can form complexes with $\mathrm{Cd}$ which may contribute to the desorption of $\mathrm{Cd}$ from the solid phase of the soil, but prevent its internalization by roots. Meda et al. (2007) partly contradicted this model, showing that $\mathrm{Cd}$-induced phytosiderophore release cannot protect maize plants from $\mathrm{Cd}$ toxicity. Instead, phytosiderophore-mediated Fe acquisition would provide an advantage under Cd stress by improving Fe uptake. Accordingly, Astolfi et al. (2014) showed that most of the genes involved in phytosiderophore biosynthesis and secretion induced by Fe deprivation were also significantly upregulated in the presence of $\mathrm{Cd}$ under Fe sufficient conditions in barley. Interestingly, the enhanced expression of phytosiderophore biosynthesis genes in roots was associated with the downregulation of $\mathrm{Cd}$ uptake transporter genes (see below). The downregulation of Cd uptake transporter expression would constitute a protective mechanism against further Cd uptake by these transporters. 
356 V. Absorption of Cd by the roots

\section{A. Location of Cd uptake on the root}

358

359

360

361

362

Laporte et al. (2013) showed that in sunflower first order lateral roots, $\mathrm{Cd}^{2+}$ influx was 2.9 times higher at root tip than at the root base. These results are consistent with those of Pineros et al. (1998), who observed significantly higher Cd influx at positions 1 to $1.5 \mathrm{~mm}$ from the root apex of wheat and $N$. caerulescens seedlings. Similar profiles were observed in various young roots, in durum wheat (T. turgidum L. ssp. durum) (Farrell et al., 2005), in poplar (Populus $\times$ canescens plantlets) (He et al., 2011), in rice (Chen et al., 2018b) and in the halophyte Suaeda salsa (Li et al., 2012a). These profiles can be attributed to a higher activity of the transport systems close to the root tip, where they could be expressed at higher levels (Chen et al., 2018b) and/or benefit from more energy (Laporte et al., 2013). Higher Cd influx at the root apex could also result from the incomplete development of apoplastic barriers, thereby favouring apoplastic Cd uptake (Redjala et al., 2011) in this part of the root. The Casparian strips and suberin lamellae in the endodermis and exodermis are formed away from the root apex in more differentiated parts of the roots. However, according to the modelling carried out by Laporte et al. (2013), the higher influx at the root tip would not significantly influence the overall Cd root uptake, whereas the total root surface area is indeed a major parameter.

\section{B. Mechanisms of Cd root absorption}

There is little evidence of a biological role for cadmium. Its involvement in the enzymatic system of a diatom was mentioned above (Lane et al., 2005). As in the case of $\mathrm{Zn}$ and $\mathrm{Ni}, \mathrm{Cd}$ accumulation has been proposed as a defence against herbivorsy of hyperaccumulating plants (Jiang et al., 2005; Plaza et al., 2015). It is therefore very unlikely that transport systems with specificity for a non-essential and even highly toxic metal were selected during evolution. Instead, Cd is probably taken up through the plasma membrane of root cells by transporters 
for essential elements with insufficient selectivity with respect to their substrate (Clemens, 2001).

Cadmium transport into roots was first studied through absorption kinetics, formalized using the Michaelis-Menten model (Cataldo et al., 1983; Costa and Morel, 1994; Cohen et al., 1998; Hart et al., 1998; Redjala et al., 2010a). Although considered as not Cd specific, the transport systems involved show a high affinity to the metal, with $\mathrm{Km}$ falling in the range of 0.02 to $1 \mu \mathrm{M}$. For instance, the $K_{m}$ values for $\mathrm{Cd}$ were $0.059 \mu \mathrm{M}$ and $0.067 \mu \mathrm{M}$ in bread wheat and durum wheat, respectively, whereas for $\mathrm{Zn}$, a micro-nutrient, they were $2.3 \mu \mathrm{M}$ and $3.3 \mu \mathrm{M}$ (Hart et al., 2002). The maximum influx $\left(V_{\max }\right)$ values ranged from 12 to $188 \mathrm{nmol}$ $(\mathrm{gFW})^{-1} \mathrm{~h}^{-1}$ (Lux et al., 2011). The highest values were found for the Ganges populations of the metal hyperaccumulator N. caerulescens under Fe deficient conditions (Lombi et al., 2002). Cohen et al. (1998) also found that Fe deficiency stimulated high affinity Cd uptake in Pisum sativum roots. Lombi et al. (2001) measured the $K_{m}$ and $V_{\max }$ of the Prayon (low Cd accumulator) and Ganges (high Cd accumulators) populations of N. caerulescens. They found identical $K_{m}$ values (around $0.2 \mu \mathrm{M}$ ), but the $V_{\max }$ of the Ganges population $\left(160 \mathrm{nmol}(\mathrm{gFW})^{-}\right.$ $\left.{ }^{1} \mathrm{~h}^{-1}\right)$ was significantly higher than that of the Prayon population $\left(33 \mathrm{nmol}(\mathrm{gFW})^{-1} \mathrm{~h}^{-1}\right)$. Similar $V_{\max }$ differences were found in the comparison between Calamine (Viviez) and Serpentine (Vosges) populations of the same species (Redjala et al., 2009). Since the $V_{\max }$ value is proportional to the density of membrane transporters, the difference in Cd uptake ability by the Prayon and Ganges populations could be due to a difference in the expression of a certain transporter gene with high Cd affinity.

Absorption kinetics are often biphasic in appearance, resulting from the combination of Michaelis-Menten kinetics and linear kinetics. The linear component has often been attributed to adsorption of $\mathrm{Cd}^{2+}$ on the apoplasm and therefore to incomplete desorption before the determination of Cd in the root (Hart et al., 1998; Lombi et al., 2001). However, this 
interpretation was invalidated using Cd measurement in the symplasm and apoplasm [Redjala (2009); Redjala et al. (2010a)]. The linear component would rather correspond to the entry of Cd into the symplasm via low affinity transport systems, such as ion channels for $\mathrm{Ca}^{2+}$ (Perfus-Barbeoch et al., 2002; Rodriguez-Hernandez et al., 2015; Chen et al., 2018b). In any case, this linear component significantly contributes to the root uptake only at high concentrations of $\mathrm{Cd}^{2+}$ in the medium, which do not occur in agricultural soil and are rare in contaminated soils.

In mouse-ear cress (Arabidopsis thaliana) (Figure 2, Table 1), Eide et al. (1996) showed that Fe deficiency induces the expression of an iron regulated transporter IRT1 (from the zincregulated transporter, iron-regulated transporter protein - ZIP family), which allows the transport of divalent metals such as $\mathrm{Cd}^{2+}, \mathrm{Co}^{2+}, \mathrm{Mn}^{2+}$ and $\mathrm{Zn}^{2+}$, in addition to $\mathrm{Fe}^{2+}$, when expressed in yeast (Eide et al., 1996; Korshunova et al., 1999). AtIRT1 is mainly expressed in root epidermis and to a lesser extent in root cortex (Vert et al., 2002). Cd accumulation is strongly reduced in an irtl knockout mutant under Fe deficient conditions (Vert et al., 2002). Cohen et al. (1998) proposed that the up-regulation of an IRT1 orthologue accounts for elevated Cd uptake under Fe deficiency in Pisum sativum. Even though the IRT1 homologue in barley is also able to transport $\mathrm{Fe}^{2+}, \mathrm{Zn}^{2+}$, and $\mathrm{Cd}^{2+}$ when expressed in yeast (Pedas et al. (2008); (Wu et al., 2016a), in planta, HvIRT1 mainly controls $\mathrm{Mn}^{2+}$ uptake (Long et al., 2018). In rice (Figure 3, Table 1), OsIRT1, as well as its homologue OsIRT2, are predominantly expressed in roots in Fe deficient conditions and are able to transport $\mathrm{Cd}^{2+}$ when expressed in yeast. Iron deficiency both enhanced their expression as well as Cd uptake and translocation (Ishimaru et al., 2006; Nakanishi et al., 2006). IRT1 may also be involved in Cd uptake by the hyperaccumulator N. caerulescens (Lombi et al., 2002; Plaza et al., 2007), but whether its activity accounts for the particularly high ability of the Ganges population to accumulate Cd remains to be formally demonstrated. In this species (Figure 4), 
431 NcZNT1, the orthologue of AtZIP4, was presented as mediating high-affinity $\mathrm{Zn}^{2+}$ uptake as well as low affinity $\mathrm{Cd}^{2+}$ uptake (Pence et al., 2000)(Table1). However, this finding was contradicted by Milner et al. (2012) who reported that NcZNT1 can transport Zn, but not Cd when expressed in yeast or A. thaliana. More recently, the results of Lin et al. (2016a) confirmed those of Pence et al. (2000). They explained the discrepancy by the fact that the NcZNT1 cDNA sequence used by Milner et al. (2012) lacked the original ATG start codon, which would have affected the normal function and cellular localization of the aberrant NcZNT1 protein.

Transport proteins of the NRAMP (natural resistance-associated macrophage protein) family are also involved in the Cd uptake and more generally in its transport in plants. AtNRAMP 1/3/4 transport $\mathrm{Fe}^{2+}, \mathrm{Mn}^{2+}$ and $\mathrm{Cd}^{2+}$ when expressed in yeast (Thomine et al., 2000).

AtNRAMP3/4 are involved in Fe, Mn and Cd efflux from the vacuole (Lanquar et al., 2005; Lanquar et al., 2010; Pottier et al., 2015). AtNRAMP1 is responsible for high-affinity Mn uptake by $A$. thaliana roots (Cailliatte et al., 2010). Its role in Cd uptake in planta has yet to be investigated. In rice, OsNRAMP1, which transports Fe, was suggested to contribute to Cd uptake and transport within rice plants, but did not transport Mn (Takahashi et al., 2011) (Table 1), while NRAMP1 from Malus baccata may be involved in Mn, as well as for Fe and Cd transport (Xiao et al., 2008). OsNRAMP5 turned out to be the major transporter for the uptake of $\mathrm{Mn}$ and $\mathrm{Cd}$ in rice roots (Ishikawa et al., 2012; Ishimaru et al., 2012; Sasaki et al., 2012; Tang et al., 2017) (Table 1). Ishimaru et al. (2012) reported that OsNRAMP5 is expressed in the epidermis, exodermis, and outer layers of the cortex as well as in tissues around the xylem. Sasaki et al. (2012) detected the protein only in exodermis and endodermis. OsNRAMP5 loss of function mutants are defective when it comes to high affinity Cd uptake into the roots (Sasaki et al., 2012) and in Cd translocation from roots to shoots (Yang et al., 2014). Consequently, these mutants accumulate $\mathrm{Cd}$ at extremely low levels in all organs 
including grain. In Triticum polonicum, TpNRAMP5 is mainly expressed in roots and basal stems, and the protein is localized in the plasma membrane. Expression of TpNRAMP5 in $A$. thaliana enhanced the accumulation of $\mathrm{Cd}, \mathrm{Co}$ and $\mathrm{Mn}$, but not that of $\mathrm{Zn}$ and Fe (Peng et al., 2018). The NRAMP5 transporter is also present in maize and in bread wheat, but displays a lower level of expression and a lower activity than in rice (Sui et al., 2018).

Several root metal uptake transporters display a polar localization. OsNRAMP5 and AtIRT1, that have been show to mediate Cd uptake are concentrated on the membrane facing the soil solution (Sasaki et al., 2012; Barberon et al., 2014). This raises the question of how metals are transferred towards the stele, from the other side of the cell facing the central cylinder. In plants, members of the cation diffusion facilitator (CDF) family are known as metal tolerance proteins (MTP). They are involved in metal efflux from the cytosol to other compartments: the apoplasm, the vacuole and the Trans Golgi Network (TGN). In rice, Ueno et al. (2015) showed that OsMTP9 is polarized on the side of the plasma membrane facing the stele and is required for efficient Mn uptake (Table 1). Working on cucumber (Cucumis sativus), Migocka et al. (2015) found that the CsMTP9 gene encodes a plasma membrane $\mathrm{H}^{+}$-coupled $\mathrm{Mn}^{2+}$ and a $\mathrm{Cd}^{2+}$ antiporter expressed exclusively in roots. CsMTP9 was shown to be involved in the efflux of $\mathrm{Mn}$ and $\mathrm{Cd}$ from root cells, thereby allowing the transport of both metals from the endodermis into the vascular cylinder for further translocation to the shoot.

Some authors have suggested that $\mathrm{Cd}$ could also enter cells through $\mathrm{Ca}^{2+}$ channels (Welch and Norvell, 1999; Perfus-Barbeoch et al., 2002; Li et al., 2012b). This is supported both by the finding that $\mathrm{Cd}$ influx is affected by $\mathrm{Ca}^{2+}$ channels blockers (Cohen et al., 1998), as well as by the correlation between $\mathrm{Cd}$ and $\mathrm{Ca}$ accumulation in numerous non-metallicolous populations of $N$. caerulescens grown (Sterckeman et al., 2017). The work of Chen et al. (2018b) on rice indicates that the Ca channels OsANN4 and OsGLR3.4 can mediate Cd uptake in roots (Table 
1). However, their results were obtained after exposing the roots to $20 \mu \mathrm{M} \mathrm{Cd}$, which is about 1000 times higher than the concentration plants are exposed to in field conditions.

The existence of a root efflux system for Cd was suggested quite a long time ago, in particular by Costa and Morel (1993) from the absorption kinetics of white lupin (Lupinus albus). This hypothesis was further reinforced by studies showing that a small portion of the radioactive Cd deposited on lettuce, radish and bean leaves was transferred to the rhizosphere soil (Fismes et al., 2005). More recently, the PDR8 protein (pleiotropic drug resistance), expressed in all cells of $A$. thaliana, but more intensely in the root hairs and epidermis, has been shown to be responsible for Cd efflux (Kim et al., 2007) (Table 1). This protein belongs to the large family of ATP-binding cassette (ABC) transporters, known for transporting a broad range of substrates, including ions, carbohydrates, lipids, xenobiotics, drugs and toxic metals. In addition, a small Cys-rich membrane protein, AtPCR1 (Arabidopsis plant cadmium resistance), is also able to reduce $\mathrm{Cd}$ accumulation when expressed either in yeast or $A$. thaliana protoplasts (Song et al., 2004). This protein is localized in the plasma membrane and expressed in both roots and shoot. In contrast to AtPCR2, which is a $\mathrm{Zn}$ efflux transporter (Song et al., 2010), AtPCR1does not seems to act as an efflux transporter and the mechanism by which it confers Cd resistance to the plant remains unclear.

\section{Complexation of $\mathrm{Cd}$ by organic ligands in the plant}

Cadmium can form complexes with organic ligands both in the cytosol and the vacuole. This reaction is generally considered to be a detoxification process occurring in the roots as well as in the shoots (Vögeli-Lange and Wagner, 1990; Cobbett and Goldsbrough, 2002; Clemens, 2006; Verbruggen et al., 2009a). In the articles reporting research into this process, it is often not easy to distinguish the plant organs in which it takes place. This is the reason why, unless indicated, this part of the review considers Cd complexation in both roots and shoots. 
Glutathione (GSH) and phytochelatins (PCs), are non-proteinogenic peptides involved in $\mathrm{Cd}$

506

detoxification. PCs have been extensively studied since they were discovered (Grill et al., 1985). In roots of non-hypertolerant plants, most Cd is chelated by PCs (Verbruggen et al., 2009a), yet GSH and PCs also bind Cd in the shoot.

GSH (Glu-Cys-Gly), which is essential for the cellular redox balance can form complexes with various metals. Upon metal or metalloid excess, PCs, with the structure: ( $\gamma$-GluCys) ${ }_{n}$ Gly, where $\mathrm{n}=2-11$ ) are synthetized from GSH by the phytochelatin synthase (PCS) (Grill et al., 1989; Clemens et al., 1999; Ha et al., 1999; Vatamaniuk et al., 1999; Vatamaniuk et al., 2000). The gene encoding PCS was shown to be essential for Cd and As tolerance (Ha et al., 1999). In numerous plant species, the synthesis of PCs is induced by exposure to Cd (Salt et al., 1997; Schat et al., 2002; Hernandez-Allica et al., 2006; Vazquez et al., 2006; Lindberg et al., 2007). The relatively soft acid character of $\mathrm{Cd}^{2+}$ leads to a strong affinity for soft sulphur donor atoms, especially for thiolates, for instance in cysteine residues (Mah and Jalilehvand, 2010). The Cd-GSH and Cd-PC complexes have been determined and characterized in vitro (Cruz et al., 2005; Chekmeneva et al., 2007; Leverrier et al., 2007; Chekmeneva et al., 2008; Mah and Jalilehvand, 2010; Jacquart et al., 2017). In vivo, the existence, the distribution and the formation kinetics of Cd-PC complexes was supported by analyses using X-ray absorption spectroscopy (Salt et al., 1995; Salt et al., 1997), small-scale gel filtration (Rauser, 2003) or fractionation techniques coupled to mass spectrometry (Persson et al., 2006).

The first step of the detoxification process is the binding of $\mathrm{Cd}^{2+}$ with $\mathrm{GSH}$ to form bisglutathionate-Cd complex, $\mathrm{GS}_{2}-\mathrm{Cd}(\mathrm{II})$. $\mathrm{GS}_{2}-\mathrm{Cd}(\mathrm{II})$ interacts with the phytochelatin synthase, a constitutively expressed enzyme, which triggers the phytochelatin synthesis and the formation of PC-Cd(II) low molecular weight complexes (LMW PC-Cd) (Vatamaniuk et 
$a l .$, 2000). LMW PC-Cd complexes are then transported into the vacuole via an ABC-type transporter (see below) to form high molecular weight, sulphide-containing complexes (HMW PC-Cd S)(Rauser, 1995).

Phytochelatin production can increase plant tolerance to Cd (Persson et al., 2006; Gasic and Korban, 2007; Brunetti et al., 2015), but this cannot be generalized. Comparing a Cd accumulating and tolerant cultivar of black oat (Avena sativa) to a Cd-sensitive one, Uraguchi et al. (2009a) observed that Cd exposure increased PC concentrations in both cultivars, thus indicating that the differences between the cultivars could not be accounted for by difference in PC synthesis. In this case, increased storage in the cell wall would appear to account for enhanced tolerance and accumulation of $\mathrm{Cd}$ (see below). Overexpression of AtPCS1 in Arabidopsis was even found in some instances to increase Cd sensitivity (Lee et al., 2003). This was attributed to a detrimental depletion of GSH in the overexpression lines.

The role of PCs in adaptation to Cd-contaminated soils has been questioned by the work of Leopold et al. (1999), who showed that Cd-complexes disappeared after 7 to 14 days of Cd exposure in the metal tolerant Silene vulgaris. This result indicated that synthesis of metalPC-complexes was transient and not necessarily important for long-term metal tolerance by plants. Wójcik et al. (2006) also observed that PC concentration increases with the increasing Cd concentration to which $N$. caerulescens is exposed, but decreases with exposure time. PCs seem to play a minor role in Cd tolerance by this hyperaccumulator (Wojcik et al., 2005b; Wójcik et al., 2006). This is consistent with the fact that in young leaves of $N$. caerulescens, around $25 \%$ of the Cd ligands were S ligands (e.g. phytochelatins, and other Cys-rich peptides), and the proportion of S ligands decreased with increasing leaf age. In senescent leaves, almost exclusively O ligands were found (Küpper et al., 2004). Schat et al. (2002); Wójcik et al. (2006) suggested that adaptive Cd tolerance was not dependent on PC-mediated sequestration. For Sun et al. (2007a), PCs are not involved in Cd transport, 
hyperaccumulation or tolerance in the metal-hypertolerant population of $S$. alfredii, while Zhang et al. (2010) showed that PCs do not detoxify Cd in the roots of this species, contrarily to what might occur in the leaves. Comparing different species and organs, Marentes and Rauser (2007) showed that phytochelatins were not necessarily the major Cd ligands. Sun et al. (2007b) concluded that PC synthesis was not the primary reason for Cd tolerance in Solanum nigrum. Moreover, strikingly, genes involved in phytochelatin synthesis or transport have not been identified in transcriptomic or genetic analyses of Cd hyperaccumulation or hypertolerance.

In addition, PCs have been implicated in long distance Cd transport. Expressing wheat PCS specifically in A. thaliana roots, Gong et al. (2003) found that PCs synthesized in roots are transported to the shoots and that this correlates with enhanced Cd transfer from root to shoot. However, later studies indicated that this is not the main pathway for $\mathrm{Cd}$ root to shoot transfer (Wong and Cobbett, 2009). Using grafts between a phytochelatin-deficient Arabidopsis mutant and the wild type, Chen et al. (2006) demonstrated that phytochelatins are also transported from shoot to roots.

\section{B. Metallothioneins and other cysteine-rich polypeptides}

Metallothioneins (MTs) are cysteine rich, low molecular weight, gene-encoded, metal-binding polypeptides that are ubiquitously found in eukaryotes and cyanobacteria (Cobbett and Goldsbrough, 2002). It has been shown that MTs play an important role in metal homeostasis and tolerance in plants (Zimeri et al., 2005; Guo et al., 2008; Ren et al., 2012; Benatti et al., 2014). Elevated expression of MT genes (MT1, MT2, MT3) has frequently been observed in metal-hyperaccumulating and hypertolerant species or populations (van Hoof et al., 2001; Mengoni et al., 2003; Roosens et al., 2005; Chiang et al., 2006; van de Mortel et al., 2006; Hassinen et al., 2007; Jack et al., 2007). However, no positive correlation between these expression levels and metal tolerance/accumulation was observed. Recently, Peng et al. 
579 (2017a) proposed that the cysteine-rich MT-like protein SpMTL could act as a cytosolic 580 chelator to detoxify Cd in the hyperaccumulator $S$. plumbizincicola (Table 1). However, this 581 role has to be confirmed in other species.

582

In Digitaria ciliaris, Kuramata et al. (2009) identified a novel gene, DcCDT1 (D. ciliaris cadmium tolerance), encoding a 55 amino acid peptide, containing 15 (27\%) cysteine residues, as well as its rice homolog, OsCDT1 (Table 1). When constitutively expressed in yeast cells and A. thaliana, this gene enhanced their Cd tolerance by limiting cellular Cd accumulation. The authors proposed that the peptide is secreted outside the cell, where it partly associates with the cell wall. It then prevents $\mathrm{Cd}$ internalization by chelating the metal at the cellular surface.

\section{Organic acids}

Carboxylic acids also contribute to Cd complexation. Salt et al. (1997) showed that during the initial stages of Cd uptake (6-12 h) by Brassica juncea seedlings, most of the intracellular Cd was bound to oxygen atoms, possibly from organic acids. The spectra of pure Cd citrate fitted relatively well with the spectra of $B$. juncea seedlings. Later, Ueno et al. (2005) showed that $\mathrm{Cd}$ is mainly associated to malate in the leaves of $N$. caerulescens. In roots and shoots of the hyperaccumulator Thlaspi praecox, Vogel-Mikuš et al. (2010) found that up to $80 \%$ of the Cd ligands are oxygen ligands provided by the cell walls (see below) and by organic acids stored in the vacuoles. In the stems and leaves of Gomphrena claussenii, a Cd tolerant species, $\mathrm{Cd}$ was mainly bound to oxalate in crystals also containing $\mathrm{Ca}$. The plant was however, exposed to very high $\mathrm{Cd}$ concentrations in hydroponics $\left(100 \mu \mathrm{M} \mathrm{CdSO}_{4}\right)$. In the roots, there was no oxalate crystals and Cd was predominantly associated to S ligands (Pongrac et al., 2018). The complexation of $\mathrm{Cd}$ by organic acids is particularly important in the epidermal cells, where the vacuoles represent $99 \%$ of the symplast volume. In the stems and leaves of the $\mathrm{Cd}$ hyperaccumulating ecotype of $S$. alfredii, $\mathrm{Cd}$ is mainly associated with oxygen ligands and the 
604

605

606

607

608

609

610

611

612

613

614

615

616

617

618

619

620

621

622

623

624

625

626

627

majority (about $70 \%$ in leaves and $47 \%$ in stems) is bound to malic acid, i.e. the major organic acid in the shoots (Tian et al., 2011).

\section{Storage of $\mathrm{Cd}$ in vacuoles of roots and shoots}

The vacuole is an important storage organelle for many ions. As with complexation with organic ligands, transport from the cytosol into the vacuole is regarded as a process increasing plant tolerance and plant ability to accumulate high levels of toxic metallic ions, occurring in either the roots or the shoots. In the leaves of $N$. caerulescens, Wojcik et al. (2005a) found that $\mathrm{Cd}$ accumulates in vacuoles and suggested these are the main compartments for storage and detoxification of this metal. In the literature, it is sometimes difficult to distinguish between root and aerial parts with respect to the nature of the $\mathrm{Cd}$ transporters present in the vacuole membrane, the tonoplast. This is why this part of the review concerns storage in vacuoles in both below- and above-ground organs.

Several transport pathways mediate $\mathrm{Cd}$ sequestration in the vacuole either as free $\mathrm{Cd}$ or PC-

Cd complexes. They use either ATP hydrolysis or the proton gradient across the vacuolar membrane as sources of energy to drive substrate accumulation inside the vacuole. Cadmium can be transported into the vacuole by means of a $\mathrm{H}^{+} /$cation-antiporters designated as CAX (CAtion eXchanger), that use the proton gradient to mediate divalent cation storage in the vacuole (Salt and Wagner, 1993; Hirschi et al., 2000; Pittman et al., 2004; Shigaki and Hirschi, 2006; Shen et al., 2012). Among the members of the CAX family that have been characterized as calcium transporters, CAX1, CAX2 and CAX4 have the ability to transport Cd as well (Table 1). In A. thaliana, CAX2 is strongly expressed in the leaf vascular tissue, in vegetative meristematic tissue, as well as in the root vascular tissue and in the root tip (Pittman et al., 2004). Koren'kov et al. (2007) compared seven different CAX genes from A. 
thaliana in transformed tobacco. They showed that all the genes are involved in the transport of $\mathrm{Cd}^{2+}, \mathrm{Ca}^{2+}, \mathrm{Zn}^{2+}$, and $\mathrm{Mn}^{2+}$ to varying degrees, but that AtCAX4 and AtCAX2 have a higher $\mathrm{Cd}^{2+}$ selectivity. AtCAX4 is expressed at higher levels in the roots. Korenkov et al. (2009) showed that expression of AtCAX2 or AtCAX4 in transformed tobacco roots reduces

Cd translocation to the aerial parts by promoting sequestration of the metal in the roots. In addition, CAX1a is expressed in vacuoles of barley (H. vulgare) exposed to $\mathrm{Cd}$, thus suggesting that this protein plays a role in Cd vacuolar storage (Schneider et al., 2009). Expression of AtCAX1 in petunia enhanced Cd tolerance and accumulation (Wu et al., 2011). Moreover, Baliardini et al. (2015) suggested that the role of CAX1 in Cd tolerance is not linked to $\mathrm{Cd}$ transport but in maintaining cytosolic $\mathrm{Ca}$ levels to avoid uncontrolled ROS accumulation. The evidence that CAX transporters are involved in $\mathrm{Cd}$ transport in planta come from overexpression experiments, whereas loss of function would be necessary to determine their actual contribution to $\mathrm{Cd}$ storage and $\mathrm{Cd}$ tolerance. Membrane transporters of the CDF family do not seem to be involved into vacuolar Cd sequestration. Indeed, neither vacuolar MTP from A. thaliana nor its hyperaccumulator relative A. halleri displayed Cd transport activity (Dräger et al., 2004; Desbrosses-Fonrouge et al., 2005; Arrivault et al., 2006). Accordingly, MTP1 was identified as a QTL for Zn tolerance, but not for Cd tolerance in A. halleri (Courbot et al., 2007; Willems et al., 2007).

The $\mathrm{P}_{1 \mathrm{~B}}$-ATPase subfamily HMA (for Heavy Metal Associated) also plays a role in Cd sequestration in vacuoles. Morel et al. (2009) showed that AtHMA3 is located in the vacuolar membrane of $A$. thaliana (Table 1). In shoots, AtHMA3 has a high expression level in guard cells, hydathodes, vascular tissues, while in roots, it is expressed in the stellar cells and at the apex. AtHMA3 participates in the vacuolar storage of $\mathrm{Cd}$, improving plant tolerance to the metal (Morel et al., 2009). A homologous gene, OsHMA3, is a major determinant of the variation in $\mathrm{Cd}$ accumulation in shoots and grains among rice cultivars (O. sativa) (Ueno et 
653

654

655

656

657

658

659

660

661

662

663

664

665

666

667

668

669

670

671

672

673

674

675

676

677

al., 2010; Miyadate et al., 2011; Sui et al., 2019). OsHMA3 is mainly expressed in the tonoplast of root cells. OsHMA3 was found to limit $\mathrm{Cd}$ translocation from roots to shoot by selectively sequestrating Cd into root vacuoles (Ueno et al., 2010). Mutations leading to a loss of functionality of the OsHMA3 transporter in the roots explain the elevated accumulation of Cd in the aerial parts of several indica rice cultivars, Jarjan (Ueno et al., 2011a; Yan et al., 2016), Hitomebore (Tanaka et al., 2016) and Cho-Ko-Koku (Miyadate et al., 2011), compared to japonica cultivars. Sun et al. (2019) showed that a Gly to Arg substitution at position 512 in OsHMA3 causes some japonica rice cultivars to accumulate larger amounts of $\mathrm{Cd}$ in the shoots and grains. Interestingly, variations in the coding sequence of AtHMA3 also account for the variations in shoot $\mathrm{Cd}$ accumulation among $A$. thaliana accessions (Chao et al., 2012), in Brassica rapa (Zhang et al., 2019) and in Durum wheat (Maccaferri et al., 2019). Overexpression of a functional OsHMA3 in a japonica rice cultivar further decreased Cd accumulation in shoots and grains (Ueno et al., 2010). Shao et al. (2018) fused a promotor of OsHMA2 (highly expressed in the node) to OsHMA3. The consequence was an enhanced expression of OsHMA3 and a modification in the tissue localization of the transporter, which was also expressed in the nodes. This resulted in a reduced $\mathrm{Cd}$ accumulation in grain due to the sequestration of $\mathrm{Cd}$ in the vacuoles of various tissues. The genome of the metal hyperaccumulator $N$. caerulescens also encodes one or several HMA3 homologues that are localized in the vacuolar membrane and allow Cd sequestration (Ueno et al., 2011b). In contrast with rice and $A$. thaliana, NcHMA3 is also strongly expressed in shoot tissues and is responsible for Cd sequestration in leaf cell vacuoles (Ueno et al., 2011b; Mishra et al., 2017). The latter suggested that greater expression of NcHMA3 would explain the hyperaccumulation of Cd by certain populations (e.g. Ganges) of this species (Ueno et al., 2011b). In the hyperaccumulator S. plumbizincicola (Crassulaceae), SpHMA3 is also strongly expressed in shoots and is localized in the tonoplast. It plays an important role in $\mathrm{Cd}$ 
678 detoxification in young leaves and stems by sequestrating the metal in the vacuole (Liu et al., 679 2017). Working on HMA3 from soybean (Glycine max), Wang et al. (2018) proposed that 680 GmHMA3 limits the translocation of $\mathrm{Cd}$ from the roots to the stems, by sequestrating Cd into 681 the root endoplasmic reticulum (ER). This is surprising, as Cd toxicity would be expected to 682 be very high in the ER, probably interfering with disulphide bound formation.

683 It has recently been proposed that the homeodomain-containing protein, OsHB4a was 684 responsible for Cd sensitivity and accumulation in the leaves and grains of rice plants through 685 the regulation of other genes, such as OsHMA2 and OsHMA3 (Ding et al., 2018). OsHB4a is 686 up-regulated upon $\mathrm{Cd}$ exposure and favours xylem loading and $\mathrm{Cd}$ translocation. Moreover, 687 miR166 a well-conserved miRNA present in all plants, targets OsHB4a for degradation. The 688 expression of miR166 decreases upon $\mathrm{Cd}$ exposure. Cd exposure thus favours its 689 accumulation and toxicity in rice by simultaneously up-regulating OsHB4a and downregulating its inhibitor, miR166.

691

692

693

694

695

696

697

698

699

700

701

Based on their up-regulation upon $\mathrm{Cd}$ exposure and their localization at the vacuolar membrane, the MRP3 transporters of the ABC family from mouse-ear cress and barley have been suggested as driving the influx of PC-Cd complexes into the vacuole (Tommasini et al., 1998; Schneider et al., 2009) (Table 1). A similar function has been demonstrated for the AtMRP7 transporter (Wojas et al., 2009). In the case of AtMRP7 or AtMRP3, whether Cd is transported as a complex with PC rather than as a free ion, was not determined. However, Park et al. (2012) showed that transporters of the same subfamily, AtABCC1/AtMRP1 and AtABCC2, are indeed responsible for the sequestration of phytochelatin-Cd complexes into the root vacuoles of $A$. thaliana (Table 1). Song et al. (2014) demonstrated that a vacuolar transporter for PC-Cd was also present in barley and proposed that it could be an ABC-type transporter, such as AtABCC1 or AtABCC2. In addition, AtABCC3 increases vacuolar Cd 
through the transport of Cd-phytochelatin complexes. Its activity is regulated by $\mathrm{Cd}$ and coordinated with that of AtABCC1 and AtABCC2 (Brunetti et al., 2015).

In contrast with CAX, MTPs, HMA and ABCCs, transporters belonging to the NRAMP family participate in Cd efflux from the vacuole (Table 1). In A. thaliana, AtNRAMP3 and AtNRAMP4 both reside on the vacuolar membrane (Thomine et al., 2003; Lanquar et al., 2005) and can transport Cd when expressed in yeast (Thomine et al., 2000). Consistent with its redundant function in $\mathrm{Cd}$ efflux from root vacuoles, nramp3nramp 4 double mutant in the WS accession, which harbours a functional HMA3 gene, accumulates greater $\mathrm{Cd}$ concentrations in roots than the wild type (Chao et al., 2012; Pottier et al., 2015). Conversely, overexpression of AtNRAMP4 decreases root Cd concentration. In the hyperaccumulator $N$. caerulescens, NcNRAMP3 and NcNRAMP4 have the same protein function as their $A$. thaliana homologues, but are expressed at higher levels (Oomen et al., 2009). The efflux of $\mathrm{Cd}$ and $\mathrm{Zn}$ from root vacuoles driven by NcNRAMP3 and 4 may be required for the efficient translocation of these metals from roots to shoots in $N$. caerulescens.

\section{Interactions of $\mathrm{Cd}$ with the apoplast}

\section{A. Transport through the apoplast}

The root apoplast is a compulsory pathway for $\mathrm{Cd}^{2+}$ and for $\mathrm{Cd}$ complexes before entering the symplast. The solute is considered to move radially in the root apoplast by diffusion and advection, before reaching the plasma membrane and crossing it through transport proteins (see above). Cd needs to use the symplastic route to cross the exodermis and/or the endodermis cell layers, where apoplastic transport is blocked by the apoplastic barriers (Casparian strip, suberine lamellae, secondary thickening). It has however been suggested that Cd could reach the xylem via the sole apoplastic pathway in the parts of the root where the apoplastic barriers are lacking or incomplete, namely the root tip, stage I endodermis and sites 
of lateral root emergence (White, 2001). This hypothesis is supported by studies showing a greater Cd influx along the few millimetres at the root tip (see above).

The relative contributions of the symplastic and apoplastic pathways to Cd loading in the xylem have yet to be determined. The work of Redjala et al. (2009); Redjala et al. (2010b) showed that apoplastic adsorption had a minor contribution to root $\mathrm{Cd}$ uptake, when compared to symplastic uptake at low concentration exposure, such as that in soil solution. Nevertheless, Feng et al. (2018) showed that, under Cd stress, endodermal apoplastic barriers were much thicker in a low $\mathrm{Cd}$ accumulating sorghum genotype than in a highly accumulating one. The weaker apoplastic barriers were considered to favour xylem loading via the apoplastic pathway in the highly accumulating genotype. Tao et al. (2017) highlighted the significance of the apoplastic pathway in Cd accumulation using a $\mathrm{Cd}$ hyperaccumulating ecotype of $S$. alfredii. The contribution of apoplast to Cd xylem loading depended on the $\mathrm{Cd}$ exposure level and represented up to $37 \%$ of total uptake. The main entry sites for apoplastic uptake were in the root apices and at the base of lateral roots, where suberin lamellae are not well-developed.

In the aerial parts, it is difficult to quantify the contribution of the apoplastic transport of Cd. The cell walls of leaves (see below) contain $\mathrm{Cd}$ that may migrate into the leaves towards the epidermis, by advection in the network of cell walls driven by the transpiration flow.

\section{B. Storage in the apoplast}

Electronegative sites of cellulose, hemicellulose and pectin chains enable the sorption of cations in the cell walls (Haynes, 1980; Grignon and Sentenac, 1991). Sorption in the apoplast is considered, together with chelation, vacuolar sequestration and translocation, as a means of Cd detoxification (Vazquez et al., 2006; Nocito et al., 2011). However, the fraction of the metal stored in this compartment appears to vary widely. When maize and pea (Pisum sativum) were cultivated and exposed to $\mathrm{Cd}$ in hydroponics, higher $\mathrm{Cd}$ levels were found in 
the cell-wall fraction of leaves and roots of maize than in those of pea. This correlated with more severe toxicity symptoms in pea (Lozano-Rodriguez et al., 1997). Based on Energy Dispersive X-ray micro-analysis in the root cortex of $A$. thaliana, Cd accumulated in the cell wall together with phosphate whereas, in the central cylinder, $\mathrm{Cd}$ was present in the cell wall as $\mathrm{Cd} / \mathrm{S}$ granular deposits in the middle lamella of the pericycle (Van Belleghem et al., 2007). In the other parts of the central cylinder, the $\mathrm{Cd} / \mathrm{S}$ granular deposits were located near the plasma membrane and not in the middle lamella. In leaves of oilseed rape (Brassica napus), Cd in cell walls represented only $11 \%$ of the metal content (Carrier et al., 2003). In tea seedlings, most of the Cd accumulated in roots, with about $12 \%$ to $30 \%$ in the cell walls, while cell wall represented $43.6-83.4 \%$ of the very low Cd content in leaves (Cao et al., 2018a). Cosio et al. (2005) showed that 33-35\% of Cd in the aerial parts of $N$. caerulescens is in the cell walls. In the case of willow (Salix viminalis) exposed to high Cd levels, the main sink of the metal was the pectin layer of collenchyme cell walls, close to the leaf veins (Vollenweider et al., 2006). Xiong et al. (2009) showed that exogenous NO increases Cd tolerance in rice plantlets by enhancing pectin and hemicelluloses content in the root cell wall, which is associated with an increase in Cd accumulation in the root cell walls and a decrease in Cd concentration the soluble fraction of leave cells. Xu et al. (2015) showed that, in $A$. thaliana, Cd itself increases the polysaccharide contents and the binding capacity of root cell walls. Among oat varieties, the highest Cd-resistance coincided with greatest $\mathrm{Cd}$ storage in the cell walls of aerial parts (Uraguchi et al., 2009a). This was also suggested by the work of Sterckeman et al. (2011), which showed an increase in Cd apoplastic fraction in maize and $N$. caerulescens roots after exposure to high $\mathrm{Cd}$ concentrations. In the hyperaccumulating species A. halleri, Meyer et al. (2015) correlated Cd induced modification in the cell wall with intraspecific variations in Cd tolerance and accumulation. The apoplast also appeared to be an important storage compartment for $\mathrm{Cd}$ in the $\mathrm{Cd}$ hyperaccumulator S. alfredii (Zhang et al., 
2010). Li et al. (2015) showed that more Cd was retained in the root cell wall of the nonhyperaccumulating ecotype (NHE) of $S$. alfredii than in the hyperacccumulating one (HE). Transcriptomic analyses also indicated an important role played by the cell wall, in the $\mathrm{Cd}$ hyperaccumulation in S. plumbizincicola (Peng et al., 2017b). As in A. thaliana, Cd treatment induced an increase in cell-wall polysaccharides (pectins and hemicelluloses) in the NHE of S. alfredii, but not in the HE. Consequently, more Cd was available for xylem loading in the HE ecotype.

It should be noted that in several of the above-cited works (Lozano-Rodriguez et al., 1997; Carrier et al., 2003; Cao et al., 2018a), as well as in others (e.g. (Fu et al., 2011; Wang et al., 2015a; Wang et al., 2015b), the method used to determine Cd (or other elements) in cell walls is questionable. Indeed, it is based on a fine grinding of the fresh tissues in a buffer solution to destroy the cells. The homogenate is generally then sieved to collect the cell walls. The filtrate is centrifuged to separate chloroplasts from other organelles and from cytosolic and vacuole solution. This procedure in liquid phase does not exclude the diffusion of $\mathrm{Cd}$ from one fraction to another during the tissue grinding and fraction separation. The content measured in each fraction might not therefore, correspond to the distribution of the metal in vivo.

\section{Translocation and reallocation of $\mathrm{Cd}$}

Cadmium concentration is often higher in the roots than in the shoots (Jarvis et al., 1976; Lozano-Rodriguez et al., 1997; Harris and Taylor, 2013; Cornu et al., 2016), and generally lower in the seeds than in the stem and leaves (Hinesly et al., 1978; Wiggenhauser et al., 2016; Chen et al., 2018a). In some species, such as lettuce (Lactuca sativa), spinach (Spinacia oleracea), cauliflower (Brassica oleracea) and oat, concentrations are higher in the shoot than in the roots when plants are grown on low Cd contaminated soils. However, when the plants are grown on more contaminated soil, the root concentration becomes higher than that of the shoots (John, 1973). In maize, Perriguey et al. (2008) observed increasingly greater 
801

802

803

804

805

806

807

808

809

810

811

812

813

814

815

816

817

818

819

820

821

822

823

824

825

concentrations in roots than in shoots and an increase in the Cd root-to-shoot ratio, as that of the $\mathrm{Cd}$ concentration in the nutrient solution rose. The ratio sharply decreased after reaching a peak, as if the root retention capacities became overloaded at this point. The sequestration of $\mathrm{Cd}$ in the roots up to a certain limit corresponds to the excluder strategy proposed by Baker (1981) for certain species. This author also defined an accumulator strategy, "where metals are concentrated in above-ground plant parts from low or high soil levels". This is the case for N. caerulescens, S. nigrum or S. alfredii (Yang et al., 2004; Wei et al., 2006; Lovy et al., 2013), which can be regarded as Cd hyperaccumulators as the Cd concentration in their shoots can reach $100 \mathrm{mg} \mathrm{Cd} \mathrm{(kg} \mathrm{DW)-1} \mathrm{(van} \mathrm{der} \mathrm{Ent} \mathrm{et} \mathrm{al.,} \mathrm{2013).}$

\section{A. Cd loading into the xylem}

HMA transporters play an important role in the loading of $\mathrm{Cd}$ in xylem vessels. As ATPases, they can transport the cation against its electrochemical gradient, from the cytosol into the xylem sap. AtHMA4 is expressed at its highest level in tissues surrounding the root vascular vessels in A. thaliana (Mills et al., 2003; Verret et al., 2004). Located in the plasma membrane and acting as an efflux pump, HMA4 plays a role in metal loading into the xylem, thereby enhancing the root-to-shoot translocation of $\mathrm{Zn}$ and $\mathrm{Cd}$ in A. thaliana (Verret et al., 2004; Mills et al., 2005). Together with AtHMA4, its paralogue AtHMA2 was shown to be involved in the root-to-shoot transfer of Cd (Wong and Cobbett, 2009; Wong et al., 2009)

(Table 1). Moreover HMA4 is also important for $\mathrm{Cd}$ translocation in the hyperaccumulator $N$. caerulescens (Papoyan and Kochian, 2004). Accordingly, in A. halleri, enhanced expression and a triplication of HMA4 was shown to be responsible for the hypertolerance to $\mathrm{Cd}$ (Courbot et al., 2007; Hanikenne et al., 2008). In N. caerulescens, the HMA4 gene is also present as multiple tandem copies (Ó Lochlainn et al., 2011) and differences in HMA4 expression correspond to the differences in $\mathrm{Cd}$ translocation and accumulation among different populations of $N$. caerulescens (Craciun et al., 2012). 
In rice, a single gene, OsHMA2, which is orthologous to AtHMA2 and AtHMA4, encodes an efflux transporter involved in Cd xylem loading. OsHMA2 is constitutively expressed in the vascular bundles of roots at the vegetative stage, and knocking-out this gene results in lower root-to-shoot translocation and grain content of Cd (Nocito et al., 2011; Satoh-Nagasawa et al., 2012; Takahashi et al., 2012; Fontanili et al., 2016). OsHMA2 is also expressed in the phloem tissue of nodes (Yamaji et al., 2013). To account for the role of OsHMA2 in the control of Cd transfer between phloem and xylem in nodes, Yamaji et al. (2013) proposed that OsHMA2 could function as an influx transporter for both $\mathrm{Cd}$ and $\mathrm{Zn}$. Such reverse transport is extremely unlikely, as the function of HMAs in metal efflux has been conserved across kingdoms and the transport mechanism involves ATP hydrolysis at the cytosolic side of the protein. Based on a $\mathrm{Cd} / \mathrm{Zn}$ reciprocal competition study, Fontanili et al. (2016) suggested that, beside OsHMA2, another transport system which is not affected by the presence of $\mathrm{Zn}^{2+}$, yet to be identified, may mediate root-to-shoot Cd translocation in rice. Recently, Hao et al. (2018) suggested that OsCCX2, a putative cation/calcium (Ca) exchanger mainly expressed in xylem region of the nodes, could be an efflux transporter, controlling Cd loading into xylem (Table 1).

Defensins are small cysteine-rich proteins, widely distributed in invertebrates, plants, and mammals and known for their involvement in the ancestral non-specific immune response and antifungal activity. Their role in metal homeostasis was first established in a work reporting that this conferred enhanced $\mathrm{Zn}$ tolerance in yeast and plant (Mirouze et al., 2006). More recently, CAL1, a defensin-like protein from rice, was found to bind $\mathrm{Cd}$ and to drive its efflux from xylem parenchyma cells to extracellular spaces (the apoplast), thus contributing to $\mathrm{Cd}$ loading into the xylem sap (Luo et al., 2018) (Table 1). Therefore, the expression of CAL1 leads to an increased $\mathrm{Cd}$ concentration in leaves, through increased translocation by the 
xylem. Whether the secretion of OsCAL1-Cd complexes indeed involves transporters or vesicular trafficking, is however still unknown.

\section{B. Transport in the xylem}

Once loaded into the root xylem, Cd migrates to the aerial parts with the xylem sap flow, driven by plant transpiration, i.e. by the gradient of water potential between the soil and the atmosphere. Numerous works show that $\mathrm{Cd}$ concentration in aerial plant parts increases with the concentration in the root exposure solution (see for instance Jarvis et al. (1976); Florijn and Van Beusichem (1993a); Lovy et al. (2013)). Moreover, various investigations have shown that $\mathrm{Cd}$ content in the xylem sap increases with $\mathrm{Cd}$ content in the exposure solution (Salt et al., 1995; Wei et al., 2007; Ueno et al., 2008; Nakamura et al., 2013; Hazama et al., 2015; Cornu et al., 2016).

Measuring Cd concentration in 69 rice accessions, Uraguchi et al. (2009b) found strong correlations between Cd levels in the xylem sap and in shoots and grains. Zhang et al. (2018) obtained similar results in the case of rape (B. napus). Harris and Taylor (2013) demonstrated the importance of root-to-shoot translocation in the accumulation of $\mathrm{Cd}$ in durum wheat grain. Together, these results demonstrate the importance of xylem transport for shoot $\mathrm{Cd}$ accumulation across species. However, the transpiration rate generally only slightly affects the root-to-shoot translocation of Cd (Van der Vliet et al., 2007; Liñero et al., 2016), probably because it is always sufficient to transport the $\mathrm{Cd}$ absorbed by the roots to the shoots.

\section{Cadmium speciation in the xylem sap}

Theoretically, based on the $\mathrm{pH}$ and the composition of the xylem sap, Cd could be present as a free ion or involved in various complexes with sulfhydryl $(\mathrm{SH})$, or N- or O-based groups.

Cadmium could be linked to cysteine-containing molecules, such as glutathione or phytochelatins, organic and amino acids (Welch and Norvell, 1999). 
White et al. (1981) have shown that Cd forms negatively-charged complexes in soybean and tomato xylem sap. In soybean, Cataldo et al. (1988) found Cd as a single, slightly anionic species and as a cationic component, which appeared to be inorganic $\mathrm{Cd}$. Citric acid promotes the translocation of $\mathrm{Cd}$ in tomato, which may be due to the formation of citrate $\mathrm{Cd}$ complexes in the xylem (Senden et al., 1995). In contrast, in the xylem sap of B. juncea, Salt et al. (1995) found that $\mathrm{Cd}$ is coordinated either with oxygen or with nitrogen, which excludes a complexation by PCs or MTs. Based on the analysis of low molecular weight compounds in the xylem sap of B. juncea, Wei et al. (2007) calculated that the Cd speciation was $33 \%$ organic acid-Cd and $67 \%$ inorganic anion- $\mathrm{Cd}$ in plants exposed to a low $\mathrm{Cd}$ concentration $\left(10^{-8} \mathrm{M}\right)$. In the xylem of plants exposed to $10 \mu \mathrm{M} \mathrm{Cd}$, the calculated $\mathrm{Cd}$ speciation was $1 \%$ $\mathrm{PC}-\mathrm{Cd}, 35 \%$ organic acid- $-\mathrm{Cd}$, and $64 \%$ inorganic anion- $\mathrm{Cd}$.

According to Ueno et al. (2008), based on nuclear magnetic resonance measurement and modelling of chemical speciation, $\mathrm{Cd}$ is essentially present as a free ion in the xylem sap of the hyperaccumulator $A$. halleri. In castor bean plants (Ricinus communis) exposed to $1 \mu \mathrm{M}$ Cd for 3 weeks, $92 \%$ of the Cd in xylem was found to be present as a free cation (Hazama et al., 2015). In sunflower exposed to low and realistic Cd concentrations (2.5 nM or $20 \mathrm{nM})$, Cornu et al. (2016) determined that the fraction of free $\mathrm{Cd}$ ion in the xylem sap was around $50 \%$. These results are difficult to reconcile, as they suggest that depending on the species and on the $\mathrm{Cd}$ concentration in the medium, Cd may be transported within the xylem both as complexes with organic and inorganic acids, but also as a hydrated free cation.

\section{Xylem unloading and Cd distribution in shoots}

After their long-distance transport in the xylem sap towards the aerial parts of the plant, mineral ions are unloaded from the xylem vessels to be distributed in the other leaf tissues

(Figure 5). Xylem unloading of $\mathrm{Cd}$ is expected to follow the same process as the nutrient ions. However, even for nutrients, this process has yet to be completely described (Shabala, 2007). 
899 Because of water evaporation, element concentration in the xylem sap of the leaves can

900 potentially increase strongly. To prevent toxic salt excess, plants have evolved mechanisms of

901 xylem unloading in leaves. These mechanisms take place in the highly-branched network of

902 major and minor veins crossing the leaf blade. The ions may then be transported from the

903 xylem parenchyma towards leaf cells via symplastic pathways. There is very little information

904 about the transport systems responsible for the unloading of $\mathrm{Cd}$ from the xylem. $\mathrm{Cd}^{2+}$

905 probably enters the leaf cells using transport proteins dedicated to nutrients (Fe, $\mathrm{Mn}, \mathrm{Zn}$ ), as

906 occurs during root absorption. In the shoot of $N$. caerulescens, HMA4 and HMA3 expression

907 is highest in the bundle sheath of the vein, while for $A$. halleri, these proteins are expressed in

908 greater amounts in the mesophyll. However, their role in the distribution and storage of Cd

909 (and $\mathrm{Zn}$ ) in the shoot is unclear and the transport pathway to the epidermis, in the case of $N$.

910 caerulescens, remains unknown (Mishra et al., 2017).

911 Cosio et al. (2004) measured the Michaelis-Menten kinetic parameters $\left(K_{m}, V_{\max }\right)$ of Cd

912 uptake by mesophyll protoplasts of N. caerulescens (Ganges and Prayon populations) and of

913 A. halleri. They observed no significant difference between the three plants, although $N$.

914 caerulescens Ganges and A. halleri were both Cd hyperaccumulators while N. caerulescens

915 Prayon accumulates $\mathrm{Cd}$ at a lower level. The authors suggested the existence of regulation

916 mechanisms upstream of the plasma membrane of leaf mesophyll cells to explain the

917 differences in shoot accumulation between populations. Alternatively, Cd accumulation may

918 be driven downstream by enhanced sequestration into vacuoles. Pre-exposure of the plants to

919 Cd induced an increase in Cd accumulation in protoplasts of "Ganges", whereas it reduced Cd

920 accumulation in A. halleri. Cosio et al. (2004) suggested that several parallel transport

921 systems could be responsible for $\mathrm{Cd}$ internalization. These could be the $\mathrm{Zn}$ and Ca uptake

922 pathways for the Prayon accession, whilst other as yet to be described transporters would be

923 used in the Ganges accession. 
924 Cosio et al. (2005) showed that at very low Cd exposure, the metal was preferentially located 925 in the young leaves of $N$. caerulescens, while at higher exposures, the metal accumulated 926 more in the older leaves. In both Ganges and Prayon populations, Cd was present mainly at

927 the edges of the leaves, where it was much more concentrated in the epidermal cells,

928 particularly in the large ones, than in the mesophyll cells. The relationship between cell size

929 and $\mathrm{Cd}$ concentration in the epidermis suggests that vacuolar sequestration may be a driving

930 force for Cd distribution in leaves. Cadmium hotspots spread across the entire limb surface

931 were also observed. These correspond to the necrotic spots visible on the leaves of the Prayon

932 population. Cadmium is not only concentrated in vacuoles, but also in cell walls, which

933 together account for up to $35 \%$ of the metal in the leaves (Cosio et al., 2005).

934 Measuring Cd uptake kinetics from leaf sections on N. caerulescens, Ebbs et al. (2009)

935 observed higher $K_{m}$ and higher $V_{\max }$ for the leaf mesophyll cells in the Prayon accession than

936 for that of the Ganges. Using influx measurements in various types of leaf protoplasts from

937 the Ganges accession, Leitenmaier and Küpper (2011) confirmed that sequestration in the

938 vacuole indeed drives Cd uptake into cells. These authors also showed that the influx into

939 specific so-called epidermal storage cells was stronger than in the other protoplasts of the

940 epidermis and mesophyll. This indicates that the storage of $\mathrm{Cd}$ in epidermal tissues is due to

941 active Cd uptake rather than to transpiration, in contrast to what had been suggested for Indian

942 mustard (B. juncea) (Salt et al., 1995).

943 These results are in line with previous findings in Silene vulgaris. In this species, Cd

944 preferentially accumulates in the lower epidermis, independently of the transpiration flow

945 (Chardonnens et al., 1998). In Noccaea praecox, another Cd and Zn hyperaccumulator, the

946 Cd concentration is twice as high in the upper and lower leaf epidermis than in the mesophyll

947 (Vogel-Mikus et al., 2008). However, because of the larger volume of the mesophyll

948 compared with that of the epidermis, mesophyll should still be considered as a location where 
significant amounts of $\mathrm{Cd}$ are detoxified. In the embryo, $\mathrm{Cd}$ is also preferentially stored in the epidermis of the cotyledons of N. praecox (Vogel-Mikus et al., 2007). Studies on N. praecox and on A. halleri confirmed that vacuolar sequestration as a complex with organic acids, and binding to the cell walls are the main mechanisms allowing $\mathrm{Cd}$ accumulation in shoots. They also indicated that Cd-thiolate complexes would be the species transported through phloem (Vogel-Mikuš et al., 2010; Huguet et al., 2012).

Ueno et al. (2005) found that Cd formed complexes with malate, probably located in leaf vacuoles of $N$. caerulescens (Ganges accession). In S. alfredii, Cd also appeared to be stored as malate in vacuoles of parenchyma tissues (pith, cortex, and mesophyll) thanks to efficient Cd transport across the tonoplast and a constitutively high concentration of malate in the vacuoles (Tian et al., 2011; Tian et al., 2017). .

In the case of willow (Salix viminalis) exposed to various $\mathrm{Cd}$ concentrations, $\mathrm{Cd}$ is located at the tips and edges of the young leaves, as well as at the base of the older leaves. This localization coincides with necrotic spots (Cosio et al., 2006). Vollenweider et al. (2006) noted that in willow leaves, the pectin-rich layers of the collenchyma cell walls of the veins are the main Cd sink. They also observed lesions in the phloem, thus suggesting that retranslocation of $\mathrm{Cd}$ occurs through this pathway. In the leaves of $A$. thaliana, Van Belleghem et al. (2007) detected Cd in tracheids, but not in the mesophyll tissue. Based on the high symplastic and apoplastic sequestration of $\mathrm{Cd}$ in the root parenchyma, combined with retranslocation from the leaves via the phloem, the authors suggested that $A$. thaliana has an excluding strategy. This strategy is probably similar in Salix viminalis and in all other excluders, while the strategy used by hyperaccumulators is to translocate most of the metal to the shoots, where it is stored in various tissues and cell compartments. 


\section{E. Allocation through phloem}

Phloem plays a key role in the distribution of $\mathrm{Cd}$ in the aerial parts of the plant, particularly in sink organs such fruits and seeds. For instance, Kato et al. (2010) showed that the Cd concentrations in the grains of three rice varieties correlates with the Cd concentration in the phloem sap, but not with that in the xylem sap. Tanaka et al. (2007) evaluated that $91 \%$ to $100 \%$ of Cd accumulated in rice grains is transported via the phloem. Many studies of phloem flow have tried to determine the extent to which it contributes to Cd reallocation from shoots to fruits, when compared to a direct translocation from the roots.

Several works have showed that $\mathrm{Cd}$ is reallocated from leaves to fruits, grain or even roots through the phloem flow (Herren and Feller, 1997; Fismes et al., 2005; Yoneyama et al., 2010; Wei et al., 2014). Using Ca as a reference of phloem supply, Liñero et al. (2018) concluded that phloem is the main route for transporting $\mathrm{Cd}$ to sunflower seeds. They calculated that the contribution of the net remobilization from the shoot accounted for $14 \%$ of the total $\mathrm{Cd}$ amount in mature seeds. Using Cd stable isotopes to trace the metal fluxes in two durum wheat cultivars, Yan et al. (2018) showed that 50 to $60 \%$ of the $\mathrm{Cd}$ accumulated in mature grains is remobilized through phloem from pre-anthesis stores, i.e leaves and stem. However, the metal is poorly remobilized from the leaves, even during senescence. This led the authors to consider these organs as irreversible $\mathrm{Cd}$ sinks. In contrast, $\mathrm{Cd}$ from the stem is efficiently remobilized towards the seeds.

In the hyperaccumulator $S$. alfredii, Cd storage and distribution has been shown to depend on the Ca status. Calcium deficiency seems to trigger a phloem transport system that reallocates Cd from storage tissues (old leaves) to newly grown tissues (Tian et al., 2016). In durum wheat, Cakmak et al. (2000) observed a decrease in Cd reallocation with increasing Zn concentration in the nutrient solution. To account for this interaction, they suggested a competitive inhibition of Cd loading into phloem sap by $\mathrm{Zn}$. 
997 In rice, the rise in Cd concentration in the leaves is much slower than the flow of xylem sap.

998 Indeed under direct observation by ${ }^{107} \mathrm{Cd}$ positron emission, the metal failed to reach leaf

999 blades after $36 \mathrm{~h}$ even though it had already reached the panicles after 7 hours of exposure

1000 (Fujimaki et al., 2010). This suggests that Cd transport is decoupled from the xylem sap flow.

1001 In addition, Cd was singularly accumulated in the nodes and redistributed to the non-exposed

1002 roots, thereby indicating a major role for phloem in the transport and distribution of Cd in the

1003 plant (Fujimaki et al., 2010). Kobayashi et al. (2013) provided evidence that Cd can be loaded

1004 into the rice phloem at the level of first node immediately after the metal has been transported

1005 from the root. Phloem is also involved in Cd translocation from root to leaves in Solanum

1006 melongena and Tagetes erecta (Qin et al., 2013; Qin et al., 2015).

1007 OsIRT1 is expressed in the rice phloem, in stem and leaves and has been suggested to

1008 transport Fe into phloem cells (Ishimaru et al., 2006). This transporter may therefore also

1009 contribute to the loading of Cd into the phloem. OsLCT1, the rice homologue of the low

1010 affinity cation transporter LCT1, identified in a wheat cDNA library (Clemens et al., 1998) is

1011 expressed in the nodes and leaf blades at rice reproductive stages (Table 1). This phloem Cd

1012 transporter would appear to be responsible for Cd delivery to rice grains, probably by

1013 mediating xylem to phloem Cd transfer in the nodes and/or re-translocation of Cd from leaves

1014 to grains (Uraguchi et al., 2011; Uraguchi et al., 2014). In addition, Yamaji and Ma (2017)

1015 suggested that OsHMA2, which is highly and constitutively expressed in the nodes, close to

1016 phloem in vascular bundles, could also be involved in mediating $\mathrm{Cd}$ (and $\mathrm{Zn}$ ) transfer from

1017 the xylem sap to the phloem.

\section{F. Cadmium speciation in the phloem sap}

1019 Mendoza-Cozatl et al. (2008) found high ratios between PCs and Cd and between glutathione 1020 (GSH) and Cd in the phloem sap of B. napus. They hypothesized that the metal could be complexed with these compounds, which would then act as long-distance Cd carriers. Kato et 
1022

1023

1024

1025

1026

1027

1028

1029

1030

1031

1032

1033

1034

1035

1036

1037

1038

1039

1040

1041

1042

1043

1044

1045

al. (2010) showed that, in rice phloem sap, Cd may bind to a $13 \mathrm{kDa}$ protein distinct from MT. Cd is also associated to SH compounds, probably PCs and GSH. Hazama et al. (2015) studied the speciation of $\mathrm{Cd}$ in the phloem sap of the castor bean (R. communis). Based on size-exclusion HPLC, they found that about $50 \%$ of the metal is bound to Cd-containing proteins or peptides, mixtures of proteins and PCs (such as PC4 and PC3) as well as complexes with GSH and PC2.

\section{Interaction of Cd with other elements}

Cadmium absorption by roots can be affected by the other elements in the soil solution, in three ways. First, as mentioned above, some anions such as $\mathrm{Cl}^{-}, \mathrm{NO}_{3}{ }^{-}$, or $\mathrm{SO}_{4}{ }^{-}$, can form complexes with $\mathrm{Cd}$ and modify the diffusion and the absorption of the metal. Moreover, major ions such as $\mathrm{H}^{+}, \mathrm{Ca}^{2+}$ and $\mathrm{Mg}^{2+}$, present at concentrations several orders of magnitude higher than those of $\mathrm{Cd}$, decrease the plasma membrane surface potential, by compensating the negatively-charged lipid heads present at the external side of the plasma membrane. In the absence of negative charges, which would attract them, the local concentrations of trace cations, such as $\mathrm{Cd}^{2+}$, at the vicinity of the plasma membrane are reduced. The lower local concentration around the uptake transporters results in lower uptake (Kinraide, 1998; Wang et al., 2011; Wang et al., 2012). On the other hand, $\mathrm{Cd}^{2+}$ and other cations directly compete for transport. Using soybean in hydroponics, Cataldo et al. (1983) showed that root absorption of $\mathrm{Cd}^{2+}$ fell in the presence of $\mathrm{Cu}^{2+}, \mathrm{Fe}^{2+}, \mathrm{Mn}^{2+}$, and $\mathrm{Zn}^{2+}$, thus suggesting that these cations compete with $\mathrm{Cd}^{2+}$ to enter the root through the same transport systems. Hart et al. (2002) also observed that trace amounts of $\mathrm{Zn}$ in the exposure solution inhibit $\mathrm{Cd}$ uptake by roots of durum wheat (and vice versa), thereby indicating that the two ions compete for root uptake via the same transport systems. In contrast, Salt et al. (1997) found no competition of $\mathrm{Mn}^{2+}$ and $\mathrm{Zn}^{2+}$ with $\mathrm{Cd}^{2+}$ for root absorption by B. juncea. Sterckeman et al. (2011) exposed maize 
1046

1047

1048

1049

1050

1051

1052

1053

1054

1055

1056

1057

1058

1059

1060

1061

1062

1063

1064

1065

1066

1067

1068

1069

root plants to a $1 \mu \mathrm{M} \mathrm{Cd}$ solution with $5 \mu \mathrm{M}$ of another cation $\left(\mathrm{Ca}^{2+}, \mathrm{Co}^{2+}, \mathrm{Cu}^{2+}, \mathrm{Fe}^{2+}, \mathrm{Mg}^{2+}\right.$, $\mathrm{Mn}^{2+}, \mathrm{Na}^{+}, \mathrm{NH}_{4}^{+}, \mathrm{Ni}^{2+}, \mathrm{Pb}^{2+}$ or $\mathrm{Zn}^{2+}$ ) and found a reduction in $\mathrm{Cd}$ uptake by $\mathrm{Cu}^{2+}$ only.

The expression of many transporters of the ZIP family, such as ZNT1, is only detectable under Zn deficiency, except in Zn hyperaccumulating plants (Grotz et al., 1998; Verbruggen et al., 2009b). This up-regulation may account for the increase in Cd absorption observed under $\mathrm{Zn}$ deficiency and the lower $\mathrm{Cd}$ accumulation when $\mathrm{Zn}$ is applied as a soil or foliar fertilizer (Saifullah et al., 2016; Qaswar et al., 2017). Zinc can also affect Cd translocation, as these metals compete with each other for xylem loading by the metal pumping ATPase OsHMA2 in rice (Fontanili et al., 2016). Such competition is likely to occur in many transporters, which are not Cd specific, such as HMA4 or CAX.

There is a relationship between the Fe nutritional status of the plant and $\mathrm{Cd}$ accumulation (Chen et al., 2019). As mentioned above, Fe deficiency induces the expression of IRT1, which is responsible for $\mathrm{Cd}$ absorption. The positive effect of Fe deficiency on $\mathrm{Cd}$ uptake was observed in N. caerulescens and in A. thaliana (Lombi et al., 2002; Vert et al., 2002).

Conversely, Cd stress induces symptoms similar to those of Fe deficiency, in particular the biosynthesis and secretion of phytosiderophores, which improve Fe uptake and provides an advantage under Cd stress relative to Fe acquisition (Astolfi et al., 2014). He et al. (2017) showed that supplying $A$. thaliana with $\mathrm{Fe}^{2+}$ prevents Cd uptake by inhibiting IRT1 expression and favouring $\mathrm{Fe}^{2+}$ in its completion with $\mathrm{Cd}^{2+}$. The $\mathrm{Fe}$ transporter, NRAMP also transports Cd (Thomine et al., 2000; Takahashi et al., 2011), which suggest a possible competition between the two elements at this level (Chen et al., 2019).

Cadmium also interacts with the Fe plaque that is deposited at the root surface under certain conditions. An Fe plaque is commonly formed in various aquatic and terrestrial plant species, such as rice (O. sativa). Radial loss of oxygen from the root and oxidation by microorganisms 
cause the oxidation of ferrous to ferric iron, which precipitates at the root surface as iron hydroxide (Liu et al., 2007). The iron plaque is expected to sequester trace metals through adsorption or co-precipitation, thereby affecting the availability and uptake of these elements by the root. However, the effect of the iron plaque on Cd uptake is controversial. Liu et al. (2007); Liu et al. (2008) found that the iron plaque is of little significance for Cd uptake and accumulation by rice plants and suggested instead that root tissues control Cd uptake in rice. In contrast, Cheng et al. (2014) and Cao et al. (2018b) showed that the iron plaque indeed promotes $\mathrm{Cd}$ deposition onto root surface and limits metal accumulation in rice plants. Sebastian and Prasad (2016) also suggested that iron plaque would act as a barrier against Cd exposure, but also as an Fe source preventing $\mathrm{Cd}$ stress and $\mathrm{Cd}$-induced Fe deficiency. However, Zhou et al. (2018) found a positive correlation between $\mathrm{Cd}$ in iron plaque and $\mathrm{Cd}$ in rice plant tissues, suggesting that the plaque does not prevent $\mathrm{Cd}$ accumulation by the plant. However, the same group of authors (Zhou et al., 2015) previously reported a negative correlation between $\mathrm{Cd}$ in the iron plaque and that in the roots of 32 rice cultivars, suggesting a protective role of the plaque.

Nitrogen speciation also influences Cd root uptake independently of its effect on rhizosphere or root apoplast $\mathrm{pH}$ (see above). Indeed, in hydroponics, supplying $N$. caerulescens with $\mathrm{NO}_{3}{ }^{-}$ resulted in a doubling of the $\mathrm{Cd}$ concentration in the shoots compared with $\mathrm{NH}_{4}^{+}$supply. Moreover, when cultivating the same species in soil, Cd uptake was highest in the $\mathrm{NO}_{3}{ }^{-}$ treatment, despite the fact that a higher $\mathrm{pH}$ decreases $\mathrm{Cd}$ and $\mathrm{Zn}$ bioavailability in the rhizosphere under these conditions (Xie et al., 2009). Nitrate also enhances Cd uptake in tomato (Solanum lycopersicum) (Luo et al., 2012), potato (S. tuberosum) (Larsson Jönsson and Asp, 2013) and S. alfredii (Hu et al., 2013) grown in hydroponics. However, the mechanisms accounting for this positive effect of $\mathrm{NO}_{3}{ }^{-}$on $\mathrm{Cd}$ absorption are still unclear. It has been proposed that the uptake of $\mathrm{NO}_{3}{ }^{-}$would favour $\mathrm{Cd}$ uptake by increasing membrane 
1095

1096

1097

1098

1099

1100

1101

1102

1103

1104

1105

1106

1107

1108

1109

1110

1111

1112

1113

1114

1115

1116

1117

1118

1119

potential, while that of $\mathrm{NH}_{4}{ }^{+}$would depolarize the membrane (Monsant et al., 2010). More recently, based on results obtained with rice, Yang et al. (2016) proposed that $\mathrm{NO}_{3}{ }^{-}$enhances

Cd uptake by up-regulating the expression of IRT1.However, in the Cd accumulators $S$.

nigrum and Carpobrotus rossii, shoot $\mathrm{Cd}$ accumulation was $30 \%$ higher with $\mathrm{NH}_{4}{ }^{+}$than with $\mathrm{NO}_{3}{ }^{-}$in the nutrient solution (Cheng et al., 2016).

Some of the works cited above suggest that $\mathrm{N}$ forms can affect $\mathrm{Cd}$ absorption not only by the root, but also its translocation (Hu et al., 2013; Larsson Jönsson and Asp, 2013; Cheng et al., 2016), through as yet unknown mechanisms. Li et al. (2010) reported that Cd regulates the low affinity nitrate transporter AtNRT1.8, which controls nitrate concentration in the xylem sap. Moreover, a loss of the AtNRT1.8 function increased Cd sensitivity, thus suggesting cross-talk between $\mathrm{Cd}$ and nitrate translocation.

Nocito et al. (2002) showed that the formation of PC-Cd complexes (see above) induces an increase in sulphate uptake by maize, in order to sustain the higher sulphur demand during PC synthesis. Moreover, Cd stimulates the expression of genes involved in sulphur assimilation pathways (Harada et al., 2002; Herbette et al., 2006; Ernst et al., 2008; Liang et al., 2014; Liang et al., 2016). Wu et al. (2018) found that an excess supply of sulphate increases Cd accumulation in the leaves of Vicia faba. In rice, Yamaguchi et al. (2016) showed that Cd exposure up-regulated the transcription of the sulphate transporter SULTR1/2, as well as sulphate uptake and translocation to shoot.

Silicon ( $\mathrm{Si}$ ) is known to reduce Cd toxicity to plants (Nwugo and Huerta, 2008; Vieira da Cunha et al., 2008; Vaculík et al., 2009; Wang et al., 2015c; Rahman et al., 2017). It was reported to decrease the availability of Cd in soil (Liang et al., 2005; Vieira da Cunha et al., 2008) and decrease Cd absorption and/or translocation (Liang et al., 2005; Wang et al., 2015c; Wu et al., 2016b; Rahman et al., 2017; Shao et al., 2017), although not systematically (Vaculík et al., 2009). Silicon improves Cd sequestration and complexation, restores the 
1120

1121

1122

1123

1124

1125

1126

1127

1128

1129

1130

1131

1132

1133

1134

1135

1136

1137

1138

1139

1140

1141

1142

1143

redox balance and strengthens the antioxidant capacity of the plant (Farooq et al., 2016).

Alleviation of $\mathrm{Cd}$ toxicity by $\mathrm{Si}$ has also been attributed to enhanced binding of $\mathrm{Cd}$ to the root apoplast (Vaculík et al., 2012; Wu et al., 2016b). More recently, the work of Greger et al. (2016) on wheat (T. aestivum) showed that $\mathrm{SiO}_{3}$ down-regulated LCT1 and HMA2 and upregulated PCS1. IRT1 was down-regulated by $\mathrm{Cd}$ and up-regulated by $\mathrm{Si}$ in roots and shoot. Silicon had no effect on the expression of NRAMP1. Shao et al. (2017) showed that OsNRAMP5 and OsHMA2 were down-regulated by Si, which could explain the reduction in Cd uptake and translocation in rice exposed to silicic acid.

\section{Conclusions}

Knowledge of $\mathrm{Cd}$ accumulation mechanisms in plants has considerably progressed over recent decades. However, many uncertainties remain and this knowledge is still incomplete at various levels. Cadmium speciation in the rhizosphere solution, which controls the root uptake, is poorly understood, because of the difficulties in identifying and quantifying the species, particularly the organometallic complexes. There is also a need to better characterize the reactive sites in the soil solid phase in order to accurately predict Cd solubility.

Concerning the processes responsible for the distribution of the metal in the plant tissues and organs, much is known of the mechanisms and the factors (such as the transport systems) controlling root absorption and storage, and xylem loading. In contrast, xylem unloading, transport and storage in the stem and leaf tissues, as well as reallocation through phloem loading and transport towards the reproductive organs are still poorly understood. It is likely that future work will shed new light on the mechanisms of $\mathrm{Cd}$ distribution in aerial parts and especially to fruits and seeds.

The diversity of the transport systems involved in Cd uptake and translocation is consistent with the idea that $\mathrm{Cd}$, as a non-essential element, highjacks the pathways of certain nutrients, 
such as calcium, zinc, manganese or iron to accumulate in plants. Moreover, the pathways used by $\mathrm{Cd}$ differ according to plant species. Investigations in the model species $A$. thaliana and in rice have revealed striking differences in the uptake mechanisms, as well as commonalities in the mechanisms that allow $\mathrm{Cd}$ sequestration in roots. There will be a need to extend this knowledge to other species, including species with contrasting accumulations and crops such as lettuce, cocoa and tobacco, for which $\mathrm{Cd}$ accumulation is an important public health issue. Moreover, the precise location of root $\mathrm{Cd}$ carriers at the tissue scale, will need to be determined in the future in order to better describe Cd uptake paths into plants.

Among crop species, rice has been the subject of recent major advances. Whilst rice produces the staple diet of hundreds of millions of people in the world, it is the cereal that accumulates $\mathrm{Cd}$ at the highest level in its grains. These scientific advances are about to lead to the release of rice cultivars that accumulate much less $\mathrm{Cd}$. In contrast, few results have been obtained on bread wheat (T. aestivum) and durum wheat, whereas these cereals are responsible for the chronic exposure to Cd of a very large portion of the world population (EFSA, 2012). In the future, research should focus on the biomolecular mechanisms of $\mathrm{Cd}$ accumulation in wheat.

Recent works have suggested the involvement of new actors in Cd transport in plants, such as CAL1, a defensin-like protein, which would appear to chelate the metal and favour its xylem loading, or again the homeodomain-containing protein gene, OsHB4a, which regulates several genes involved in Cd uptake and translocation. The regulation of OsHB4a by the miR166 also indicates that other mechanisms involving micro-RNA may be important for the movement of $\mathrm{Cd}$ in a plant. The effects of $\mathrm{Si}$ or of $\mathrm{N}$ forms on $\mathrm{Cd}$ accumulation are relatively new discoveries. These correspond to complex processes, which are as yet only partly explained, but may help to improve the management of Cd-contaminated land. All these topics represent avenues of research leading to the possibility of reducing $\mathrm{Cd}$ accumulation in crops. 
1169 Acknowledgements

1170 The authors thank Dr Hélène Frérot for her careful reading of the manuscript and her

1171 suggestions for improving it.

1172 
1173

1174

1175

1176

1177

1178

1179

1180

1181

1182

1183

1184

1185

1186

1187

1188

1189

1190

1191

1192

1193

1194

1195

1196

\section{References}

Alloway, B. J. 1995. Cadmium. In: Alloway, B. J. (ed) Heavy metals in soils. Second edn. Blackie Academic \& Professional, Glasgow.

Arnold, T., Kirk, G. J. D., Wissuwa, M., Frei, M., Zhao, F.-J., Mason, T. F. D. and Weiss, D. J. 2010. Evidence for the mechanisms of zinc uptake by rice using isotope fractionation. Plant Cell Environ. 33: 370-381.

Arrivault, S., Senger, T. and Krämer, U. 2006. The Arabidopsis metal tolerance protein AtMTP3 maintains metal homeostasis by mediating $\mathrm{Zn}$ exclusion from the shoot under Fe deficiency and Zn oversupply. Plant J. 46: 861-879.

Astolfi, S., Ortolani, M. R., Catarcione, G., Paolacci, A. R., Cesco, S., Pinton, R. and Ciaffi, M. 2014. Cadmium exposure affects iron acquisition in barley (Hordeum vulgare) seedlings. Physiol. Plant. 152: 646-659.

ATSDR 2012. Toxicological profile for cadmium. U.S. Department of Health and Human Services, Public Health Service, Agency for Toxic Substances and Disease Registry, Atlanta.

Baker, A. J. M. 1981. Accumulators and excluders - strategies in the response of plants to heavy metals. J. Plant Nutr. 3: 643-654.

Baliardini, C., Meyer, C.-L., Salis, P., Saumitou-Laprade, P. and Verbruggen, N. 2015. CATION EXCHANGER1 cosegregates with cadmium tolerance in the metal hyperaccumulator Arabidopsis halleri and plays a role in limiting oxidative stress in Arabidopsis Spp. Plant Physiol. 169: 549-559.

Barberon, M., Dubeaux, G., Kolb, C., Isono, E., Zelazny, E. and Vert, G. 2014. Polarization of IRON-REGULATED TRANSPORTER 1 (IRT1) to the plant-soil interface plays crucial role in metal homeostasis. Proc. Natl. Acad. Sci. 111: 8293-8298. 
Benatti, M. R., Yookongkaew, N., Meetam, M., Guo, W.-J., Punyasuk, N., AbuQamar, S. and Goldsbrough, P. 2014. Metallothionein deficiency impacts copper accumulation and redistribution in leaves and seeds of Arabidopsis. New Phytol. 202: 940-951.

Berkelaar, E. J. and Hale, B. A. 2003a. Accumulation of cadmium by durum wheat roots: Bases for citrate-mediated exceptions to the free ion model. Environ. Toxicol. Chem. 22: $1155-1161$.

Berkelaar, E. J. and Hale, B. A. 2003b. Cadmium accumulation by durum wheat roots in ligand-buffered hydroponic culture: uptake of $\mathrm{Cd}$-ligand complexes or enhanced diffusion? Can. J. Bot. 81: 755-763.

Blaylock, M. J., Salt, D. E., Dushenkov, S., Zakharova, O., Gussman, C., Kapulnik, Y., Ensley, B. D. and Raskin, I. 1997. Enhanced accumulation of Pb in Indian mustard by soil-applied chelating agents. Environ. Sci. Technol. 31: 860-865.

Brunetti, P., Zanella, L., De Paolis, A., Di Litta, D., Cecchetti, V., Falasca, G., Barbieri, M., Altamura, M. M., Costantino, P. and Cardarelli, M. 2015. Cadmium-inducible expression of the ABC-type transporter AtABCC3 increases phytochelatin-mediated cadmium tolerance in Arabidopsis. J. Exp. Bot. 66: 3815-3829.

Cailliatte, R., Schikora, A., Briat, J.-F., Mari, S. and Curie, C. 2010. High-affinity manganese uptake by the metal transporter Nramp1 is essential for Arabidopsis growth in low manganese conditions. Plant Cell 22: 904-917.

Cakmak, I., Welch, R. M., Erenoglu, B., Römheld, V., Norvell, W. A. and Kochian, L. V. 2000. Influence of varied zinc supply on re-translocation of cadmium $\left({ }^{109} \mathrm{Cd}\right)$ and rubidium $\left({ }^{86} \mathrm{Rb}\right)$ applied on mature leaf of durum wheat seedlings. Plant Soil 219: 279-284. 
Cao, D.-J., Yang, X., Geng, G., Wan, X.-C., Ma, R.-X., Zhang, Q. and Liang, Y.-G. 2018a. Absorption and subcellular distribution of cadmium in tea plant (Camellia sinensis cv. “Shuchazao"). Environ. Sci. Pollut. Res. 25: 15357-15367.

Cao, Z.-Z., Qin, M.-L., Lin, X.-Y., Zhu, Z.-W. and Chen, M.-X. 2018b. Sulfur supply reduces cadmium uptake and translocation in rice grains (Oryza sativa L.) by enhancing iron plaque formation, cadmium chelation and vacuolar sequestration. Environ. Pollut. 238: 76-84.

Carrier, P., Baryla, A. and Havaux, M. 2003. Cadmium distribution and microlocalization in oilseed rape (Brassica napus) after long-term growth on cadmium-contaminated soil. Planta 216: 939-950.

Cataldo, D. A., Garland, T. R. and Wildung, R. E. 1983. Cadmium uptake kinetics in intact soybean plants. Plant Physiol. 73: 844-848.

Cataldo, D. A., McFadden, K. M., Garland, T. R. and Wildung, R. E. 1988. Organic constituents and complexation of nickel(II), iron(III), cadmium(II), and plutonium(IV) in soybean xylem exudates. Plant Physiol. 86: 734-739.

Chaney, R. L., Reeves, H. W., Baklanov, I. A., Centofanti, T., Broadhurst, C. L., Baker, A. J. M., Van der Ent, A. and Rosenberg, R. 2014. Phytoremediation and Phytomining: Using plants to remediate contaminated or mineralized environments. In: Rajakaruna, R., Boyd, R. S. and Harris, T. (eds) Plant Ecology and Evolution in Harsh Environments. Nova Science Publishers, New York.

Chao, D.-Y., Silva, A., Baxter, I., Huang, Y. S., Nordborg, M., Danku, J., Lahner, B., Yakubova, E. and Salt, D. E. 2012. Genome-wide association studies identify heavy metal ATPase 3 as the primary determinant of natural variation in leaf cadmium in Arabidopsis thaliana. PLOS Genetics 8: e1002923. 
Chardonnens, A. N., Bookum, W. M. T., Kuijper, L. D. J., Verkleij, J. A. C. and Ernst, W. H. O. 1998. Distribution of cadmium in leaves of cadmium tolerant and sensitive ecotypes of Silene vulgaris. Physiol. Plant. 104: 75-80.

Chekmeneva, E., Díaz-Cruz, J. M., Ariño, C. and Esteban, M. 2007. Binding of $\mathrm{Cd}^{2+}$ and $\mathrm{Zn}^{2+}$ with the phytochelatin ( $\gamma$-Glu-Cys)4-Gly: A voltammetric study assisted by multivariate curve resolution and electrospray ionization mass spectrometry. Electroanal. 19: 310-317.

Chekmeneva, E., Prohens, R., Diaz-Cruz, J. M., Ariño, C. and Esteban, M. 2008. Competitive

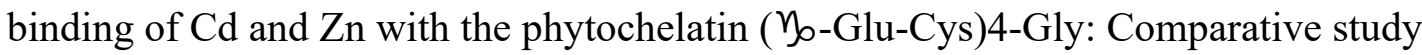
by mass spectrometry, voltammetry-multivariate curve resolution, and isothermal titration calorimetry. Environ. Sci. Technol. 42: 2860-2866.

Chen, A., Komives, E. A. and Schroeder, J. I. 2006. An improved grafting technique for mature arabidopsis plants demonstrates long-distance shoot-to-root transport of phytochelatins in Arabidopsis. Plant Physiol. 141: 108-120.

Chen, C., Cao, Q., Jiang, Q., Li, J., Yu, R. and Shi, G. 2019. Comparative transcriptome analysis reveals gene network regulating cadmium uptake and translocation in peanut roots under iron deficiency. BMC Plant Biol. 19: 35.

Chen, H., Zhang, W., Yang, X., Wang, P., McGrath, S. P. and Zhao, F.-J. 2018a. Effective methods to reduce cadmium accumulation in rice grain. Chemosphere 207: 699-707.

Chen, X., Ouyang, Y., Fan, Y., Qiu, B., Zhang, G. and Zeng, F. 2018b. The pathway of transmembrane cadmium influx via calcium-permeable channels and its spatial characteristics along rice root. J. Exp. Bot. 69: 5279-5291.

Cheng, H., Wang, M., Wong, M. and Ye, Z. 2014. Does radial oxygen loss and iron plaque formation on roots alter $\mathrm{Cd}$ and $\mathrm{Pb}$ uptake and distribution in rice plant tissues? Plant Soil 375: 137-148. 
1269 Cheng, M., Wang, P., Kopittke, P. M., Wang, A., Sale, P. W. G. and Tang, C. 2016.

1270

1271

1272

1273

1274

1275

1276

1277

1278

1279

1280

1281

1282

1283

1284

1285

1286

1287

1288

1289

1290

1291

1292

1293 Cadmium accumulation is enhanced by ammonium compared to nitrate in two hyperaccumulators, without affecting speciation. J. Exp. Bot. 67: 5041-5050.

Chiang, H. C., Lo, J. C. and Yeh, K. C. 2006. Genes associated with heavy metal tolerance and accumulation in $\mathrm{Zn} / \mathrm{Cd}$ hyperaccumulator Arabidopsis halleri: a genomic survey with cDNA microarray. Environ. Sci. Technol. 40: 6792-6798.

Choppala, G., Saifullah, Bolan, N., Bibi, S., Iqbal, M., Rengel, Z., Kunhikrishnan, A., Ashwath, N. and Ok, Y. S. 2014. Cellular mechanisms in higher plants governing tolerance to cadmium toxicity. Crit. Rev. Plant Sci. 33: 374-391.

Christensen, T. H. 1984. Cadmium soil sorption at low concentrations: I. Effect of time, cadmium load, pH, and calcium. Water Air Soil Pollut. 21: 105-114.

Cieslinski, G., Van Rees, K. C. J., Szmigielska, A. M., Krishnamurti, G. S. R. and Huang, P. M. 1998. Low-molecular-weight organic acids in rhizosphere soils of durum wheat and their effect on cadmium bioaccumulation. Plant Soil 203: 109-117.

Clemens, S. 2001. Molecular mechanisms of plant metal tolerance and homeostasis. Planta 212: $475-486$.

Clemens, S. 2006. Toxic metal accumulation, responses to exposure and mechanisms of tolerance in plants. Biochim. 88: 1707-1719.

Clemens, S., Aarts, M. G. M., Thomine, S. and Verbruggen, N. 2013. Plant science: the key to preventing slow cadmium poisoning. Trends Plant Sci. 18: 92-99.

Clemens, S., Antosiewicz, D. M., Ward, J. M., Schachtman, D. P. and Schroeder, J. I. 1998. The plant cDNA LCT1 mediates the uptake of calcium and cadmium in yeast. Proc. Natl. Acad. Sci. U.S.A. 95: 12043-12048.

Clemens, S., Kim, E. J., Neumann, D. and Schroeder, J. I. 1999. Tolerance to toxic metals by a gene of phytochelatin synthase from plants and yeast. EMBO J. 18: 3325-3333. 
Cobbett, C. and Goldsbrough, P. 2002. Phytochelatins and metallothioneins: Roles in heavy metal detoxification and homeostasis. Annu. Rev. Plant Biol. 53: 159-182.

Cobbett, C. S. 2003. Heavy metals and plants - model systems and hyperaccumulators. New Phytol. 159: 289-293.

Cohen, C. K., Fox, T. C., Garvin, D. F. and Kochian, L. V. 1998. The role of iron-deficiency stress responses in stimulating heavy-metal transport in plants. Plant Physiol. 116: 1063-1072.

Collins, R. N., Merrington, G., McLaughlin, M. J. and Knudsen, C. 2002. Uptake of intact zinc-ethylenediaminetetraacetic acid from soil is dependent on plant species and complex concentration. Environ. Toxicol. Chem. 21: 1940-1945.

Cornu, J. Y., Bakoto, R., Bonnard, O., Bussière, S., Coriou, C., Sirguey, C., Sterckeman, T., Thunot, S., Visse, M. I. and Nguyen, C. 2016. Cadmium uptake and partitioning during the vegetative growth of sunflower exposed to low $\mathrm{Cd}^{2+}$ concentrations in hydroponics. Plant Soil 404: 263-275.

Cosio, C., DeSantis, L., Frey, B., Diallo, S. and Keller, C. 2005. Distribution of cadmium in leaves of Thlaspi caerulescens. J. Exp. Bot. 56: 765-775.

Cosio, C., Martinoia, E. and Keller, C. 2004. Hyperaccumulation of cadmium and zinc in Thlaspi caerulescens and Arabidopsis halleri at the leaf cellular level. Plant Physiol. 134: 716-725.

Cosio, C., Vollenweider, P. and Keller, C. 2006. Localization and effects of cadmium in leaves of a cadmium-tolerant willow (Salix viminalis L.): I. Macrolocalization and phytotoxic effects of cadmium. Environ. Exp. Bot. 58: 64-74.

Costa, G. and Morel, J. L. 1993. Cadmium uptake by Lupinus albus (L.): Cadmium excretion, a possible mechanism of cadmium tolerance. J. Plant Nutr. 16: 1921-1929. 
Costa, G. and Morel, J. L. 1994. Efficiency of $\mathrm{H}^{+}$-ATPase activity on cadmium uptake by four cultivars of lettuce. J. Plant Nutr. 17: 627-637.

Courbot, M., Willems, G., Motte, P., Arvidsson, S., Roosens, N., Saumitou-Laprade, P. and Verbruggen, N. 2007. A major quantitative trait locus for cadmium tolerance in Arabidopsis halleri colocalizes with HMA4, a gene encoding a heavy metal ATPase. Plant Physiol. 144: 1052-1065.

Craciun, A. R., Meyer, C.-L., Chen, J., Roosens, N., De Groodt, R., Hilson, P. and Verbruggen, N. 2012. Variation in HMA4 gene copy number and expression among Noccaea caerulescens populations presenting different levels of Cd tolerance and accumulation. J. Exp. Bot. 63: 4179-4189.

Cruz, B. H., Diaz-Cruz, J. M., Arino, C. and Esteban, M. 2005. Complexation of heavy metals by phytochelatins: Voltametric study of the binding of $\mathrm{Cd}^{2+}$ and $\mathrm{Zn}^{2+}$ ions by the phytochelatin ( $\gamma$-Glu-Cys) ${ }_{3}$ Gly assisted by multivariate curve resolution. Environ. Sci. Technol. 39: 778-786.

Custos, J.-M., Moyne, C., Treillon, T. and Sterckeman, T. 2014. Contribution of Cd-EDTA complexes to cadmium uptake by maize: a modelling approach. Plant Soil 374: 497512.

de Meeûs, C., Eduljee, G. H. and Hutton, M. 2002. Assessment and management of risks arising from exposure to cadmium in fertilisers. I. Sci. Total Environ. 291: 167-187.

Degryse, F., Buekers, J. and Smolders, E. 2004. Radio-labile cadmium and zinc in soils as affected by $\mathrm{pH}$ and source of contamination. Eur. J. Soil Sci. 55: 113-122.

Degryse, F., Smolders, E. and Merckx, R. 2006. Labile Cd complexes increase Cd availability to plants. Environ. Sci. Technol. 40: 830-836. 
Degryse, F., Smolders, E. and Parker, D. R. 2009. Partitioning of metals (Cd, Co, Cu, Ni, Pb, $\mathrm{Zn)}$ in soils: concepts, methodologies, prediction and applications: a review. Eur. $J$. Soil Sci. 60: 590-612.

Desbrosses-Fonrouge, A.-G., Voigt, K., Schröder, A., Arrivault, S., Thomine, S. and Krämer, U. 2005. Arabidopsis thaliana MTP1 is a $\mathrm{Zn}$ transporter in the vacuolar membrane which mediates $\mathrm{Zn}$ detoxification and drives leaf $\mathrm{Zn}$ accumulation. FEBS Lett. 579: 4165-4174.

Ding, Y., Gong, S., Wang, Y., Wang, F., Bao, H., Sun, J., Cai, C., Yi, K., Chen, Z. and Zhu, C. 2018. MicroRNA166 modulates cadmium tolerance and accumulation in rice. Plant Physiol. 177: 1691-1703.

Dräger, D. B., Desbrosses-Fonrouge, A.-G., Krach, C., Chardonnens, A. N., Meyer, R. C., Saumitou-Laprade, P. and Krämer, U. 2004. Two genes encoding Arabidopsis halleri MTP1 metal transport proteins co-segregate with zinc tolerance and account for high MTP1 transcript levels. Plant J. 39: 425-439.

Ebbs, S. D., Zambrano, M. C., Spiller, S. M. and Newville, M. 2009. Cadmium sorption, influx, and efflux at the mesophyll layer of leaves from ecotypes of the $\mathrm{Zn} / \mathrm{Cd}$ hyperaccumulator Thlaspi caerulescens. New Phytol. 181: 626-636.

EFSA 2012. Cadmium dietary exposure in the European population. EFSA J. 10: 2551.

Eide, D., Broderius, M., Fett, J. and Guerinot, M. L. 1996. A novel iron-regulated metal transporter from plants identified by functional expression in yeast. PNAS 93: 56245628.

Ernst, W. H. O., Krauss, G.-J., Verkleij, J. A. C. and Wesenberg, D. 2008. Interaction of heavy metals with the sulphur metabolism in angiosperms from an ecological point of view. Plant Cell Environ. 31: 123-143. 
Farooq, M. A., Detterbeck, A., Clemens, S. and Dietz, K.-J. 2016. Silicon-induced reversibility of cadmium toxicity in rice. J. Exp. Bot. 67: 3573-3585.

Farrell, R. E., McArthur, D. F. E. and Van Rees, K. C. J. 2005. Net $\mathrm{Cd}^{2+}$ flux at the root surface of durum wheat (Triticum turgidum L. var. durum) cultivars in relation to cultivar differences in Cd accumulation. Can. J. Plant Sci. 85: 103-107.

Feng, J., Jia, W., Lv, S., Bao, H., Miao, F., Zhang, X., Wang, J., Li, J., Li, D., Zhu, C., Li, S. and Li, Y. 2018. Comparative transcriptome combined with morpho-physiological analyses revealed key factors for differential cadmium accumulation in two contrasting sweet sorghum genotypes. Plant Biotechnol. J. 16: 558-571.

Fismes, J., Echevarria, G., Leclerc-Cessac, E. and Morel, J. L. 2005. Uptake and transport of radioactive nckel and cadmium into three vegetables after wet aerial contamination. $J$. Environ. Quality 34: 1497-1507.

Florijn, P. J. and Van Beusichem, M. L. 1993a. Cadmium distribution in maize inbred lines: Effects of $\mathrm{pH}$ and level of Cd supply. Plant Soil 153: 79-84.

Florijn, P. J. and Van Beusichem, M. L. 1993b. Uptake and distribution of cadmium in maize inbred lines. Plant Soil 150: 25-32.

Fontanili, L., Lancilli, C., Suzui, N., Dendena, B., Yin, Y.-G., Ferri, A., Ishii, S., Kawachi, N., Lucchini, G., Fujimaki, S., Sacchi, G. A. and Nocito, F. F. 2016. Kinetic analysis of zinc/cadmium reciprocal competitions suggests a possible Zn-insensitive pathway for root-to-shoot cadmium translocation in rice. Rice 9: 16.

Fu, X., Dou, C., Chen, Y., Chen, X., Shi, J., Yu, M. and Xu, J. 2011. Subcellular distribution and chemical forms of cadmium in Phytolacca americana L. J. Hazardous Mater. 186: $103-107$.

Fujimaki, S., Suzui, N., Ishioka, N. S., Kawachi, N., Ito, S., Chino, M. and Nakamura, S.-I. 2010. Tracing cadmium from culture to spikelet: noninvasive imaging and quantitative 
characterization of absorption, transport, and accumulation of cadmium in an intact rice plant. Plant Physiol. 152: 1796-1806.

Gasic, K. and Korban, S. S. 2007. Expression of Arabidopsis phytochelatin synthase in Indian mustard (Brassica juncea) plants enhances tolerance for Cd and Zn. Planta 225: 12771285.

Gong, J.-M., Lee, D. A. and Schroeder, J. I. 2003. Long-distance root-to-shoot transport of phytochelatins and cadmium in Arabidopsis. Proc. Natl. Acad. Sci. 100: 10118-10123.

Gonneau, C., Genevois, N., Frérot, H., Sirguey, C. and Sterckeman, T. 2014. Variation of trace metal accumulation, major nutrient uptake and growth parameters and their correlations in 22 populations of Noccaea caerulescens. Plant Soil 384: 271-287.

Greger, M., Kabir, A. H., Landberg, T., Maity, P. J. and Lindberg, S. 2016. Silicate reduces cadmium uptake into cells of wheat. Environ. Pollut. 211: 90-97.

Greger, M. and Lofstedt, M. 2004. Comparison of uptake and distribution of cadmium in different cultivars of bread and durum wheat. Crop Sci. 44: 501-507.

Grignon, C. and Sentenac, H. 1991. pH and ionic conditions in the apoplast. Annu. Rev. Plant Physiol. Plant Mol. Biol. 42: 103-128.

Grill, E., Löffler, S., Winnacker, E.-L. and Zenk, M. H. 1989. Phytochelatins, the heavymetal-binding peptides of plants, are synthesized from glutathione by a specific $\gamma$ glutamylcysteine dipeptidyl transpeptidase (phytochelatin synthase). Proc. Natl. Acad. Sci. 86: 6838-6842.

Grill, E., Winnacker, E.-L. and Zenk, M. H. 1985. Phytochelatins: The principal heavy-metal complexing peptides of higher plants. Sci. 230: 674-676.

Grotz, N., Fox, T., Connolly, E., Park, W., Guerinot, M. L. and Eide, D. 1998. Identification of a family of zinc transporter genes from Arabidopsis that respond to zinc deficiency. Proc. Natl. Acad. Sci. 95: 7220-7224. 
Gu, X. and Evans, L. J. 2008. Surface complexation modelling of $\mathrm{Cd}(\mathrm{II}), \mathrm{Cu}(\mathrm{II}), \mathrm{Ni}(\mathrm{II}), \mathrm{Pb}(\mathrm{II})$ and Zn(II) adsorption onto kaolinite. Geochim. Cosmochim. Acta 72: 267-276.

Gu, X., Evans, L. J. and Barabash, S. J. 2010. Modeling the adsorption of Cd (II), Cu (II), Ni (II), $\mathrm{Pb}$ (II) and $\mathrm{Zn}$ (II) onto montmorillonite. Geochim. Cosmochim. Acta 74: 57185728.

Guo, W.-J., Meetam, M. and Goldsbrough, P. B. 2008. Examining the specific contributions of individual Arabidopsis metallothioneins to copper distribution and metal tolerance. Plant Physiol. 146: 1697-1706.

Ha, S.-B., Smith, A. P., Howden, R., Dietrich, W. M., Bugg, S., O'Connell, M. J., Goldsbrough, P. B. and Cobbett, C. S. 1999. Phytochelatin synthase genes from Arabidopsis and the yeast Schizosaccharomyces pombe. Plant Cell 11: 1153-1163.

Haghiri, F. 1973. Cadmium uptake by plants. J. Environ. Quality 2: 93-95.

Hanikenne, M., Talke, I. N., Haydon, M. J., Lanz, C., Nolte, A., Motten, P., Kroymann, J., Weigel, D. and Krämer, U. 2008. Evolution of metal hyperaccumulation required cisregulatory changes and triplication of HMA4. Nature 453: 391-396.

Hao, X., Zeng, M., Wang, J., Zeng, Z., Dai, J., Xie, Z., Yang, Y., Tian, L., Chen, L. and Li, D. 2018. A node-expressed transporter OsCCX2 Is involved in grain cadmium accumulation of rice. Frontiers Plant Sci. 9.

Harada, E., Yamaguchi, Y., Koizumi, N. and Hiroshi, S. 2002. Cadmium stress induces production of thiol compounds and transcripts for enzymes involved in sulfur assimilation pathways in Arabidopsis. J. Plant Physiol. 159: 445-448.

Harris, N. and Taylor, G. 2013. Cadmium uptake and partitioning in durum wheat during grain filling. BMC Plant Biol. 13: 103. 
Hart, J. J., Welch, R. M., Norvell, W. A. and Kochian, L. V. 2002. Transport interactions between cadmium and zinc in roots of bread and durum wheat seedlings. Physiol. Plant. 116: 73-78.

Hart, J. J., Welch, R. M., Norvell, W. A., Sullivan, L. A. and Kochian, L. V. 1998. Characterization of cadmium binding, uptake, and translocation in intact seedlings of bread and durum wheat cultivars. Plant Physiol. 116: 1413-1420.

Hassinen, V. H., Tervahauta, A. I., Halimaa, P., Plessl, M., Peräniemi, S., Schat, H., Aarts, M. G. M., Servomaa, K. and Kärenlampi, S. O. 2007. Isolation of Zn-responsive genes from two accessions of the hyperaccumulator plant Thlaspi caerulescens. Planta V225: 977-989.

Haynes, R. J. 1980. Ion exchange properties of roots and ionic interactions within the root apoplasm: Their role in ion accumulation by plants. Bot. Rev. 46: 75-99.

Hazama, K., Nagata, S., Fujimori, T., Yanagisawa, S. and Yoneyama, T. 2015. Concentrations of metals and potential metal-binding compounds and speciation of $\mathrm{Cd}, \mathrm{Zn}$ and $\mathrm{Cu}$ in phloem and xylem saps from castor bean plants (Ricinus communis) treated with four levels of cadmium. Physiol. Plant. 154: 243-255.

He, J., Qin, J., Long, L., Ma, Y., Li, H., Li, K., Jiang, X., Liu, T., Polle, A., Liang, Z. and Luo, Z.-B. 2011. Net cadmium flux and accumulation reveal tissue-specific oxidative stress and detoxification in Populus $\times$ canescens. Physiol. Plant. 143: 50-63.

He, X. L., Fan, S. K., Zhu, J., Guan, M. Y., Liu, X. X., Zhang, Y. S. and Jin, C. W. 2017. Iron supply prevents Cd uptake in Arabidopsis by inhibiting IRT1 expression and favoring competition between Fe and Cd uptake. Plant Soil 416: 453-462.

Helmke, P. A. 1999. Chemistry of cadmium in soil solution. In: McLaughlin, M. J. and Singh, B. R. (eds) Cadmium in soils and plants. Kluwer Academic Publishers, Dordrecht. 
Herbette, S., Taconnat, L., Hugouvieux, V., Piette, L., Magniette, M. L. M., Cuine, S., Auroy, P., Richaud, P., Forestier, C., Bourguignon, J., Renou, J. P., Vavasseur, A. and Leonhardt, N. 2006. Genome-wide transcriptome profiling of the early cadmium response of Arabidopsis roots and shoots. Biochim. 88: 1751-1765.

Hernandez-Allica, J., Garbisu, C., Becerril, J. M., Barrutia, O., Garcia-Plazaola, J. I., Zhao, F. J. and McGrath, S. P. 2006. Synthesis of low molecular weight thiols in response to Cd exposure in Thlaspi caerulescens. Plant Cell Environ. 29: 1422-1429.

Herren, T. and Feller, U. 1997. Transport of cadmium via xylem and phloem in maturing wheat shoots: Comparison with the translocation of zinc, strontium and rubidium. Ann. Bot. 80: 623-628.

Hill, K. A., Lion, L. W. and Ahner, B. A. 2002. Reduced Cd accumulation in Zea mays: A protective role for phytosiderophores? Environ. Sci. Technol. 36: 5363-5368.

Hinesly, T. D., Alexander, D. E., Ziegler, E. L. and Barrett, G. L. 1978. Zinc and Cd accumulation by corn inbreds grown on sludge amended soil. Agron. J. 70: 425-428.

Hinsinger, P., Plassard, C., Tang, C. and Jaillard, B. 2003. Origins of root-mediated pH changes in the rhizosphere and their responses to environmental constraints: A review. Plant Soil 248: 43-59.

Hirschi, K. D., Korenkov, V. D., Wilganowski, N. L. and Wagner, G. J. 2000. Expression of Arabidopsis CAX2 in Tobacco. Altered metal accumulation and increased manganese tolerance. Plant Physiol. 124: 125-134.

Holm, P. E., Andersen, B. B. H. and Christensen, T. H. 1996. Cadmium solubility in aerobic soils. Soil Sci. Soc. Am. J. 60: 775-780.

Honjo, M. N. and Kudoh, H. 2019. Arabidopsis halleri: a perennial model system for studying population differentiation and local adaptation. AoB Plants 11. 
Hu, P., Yin, Y.-G., Ishikawa, S., Suzui, N., Kawachi, N., Fujimaki, S., Igura, M., Yuan, C., Huang, J., Li, Z., Makino, T., Luo, Y., Christie, P. and Wu, L. 2013. Nitrate facilitates cadmium uptake, transport and accumulation in the hyperaccumulator Sedum plumbizincicola. Environ. Sci. Pollut. Res. 20: 6306-6316.

Huguet, S., Bert, V., Laboudigue, A., Barthès, V., Isaure, M.-P., Llorens, I., Schat, H. and Sarret, G. 2012. Cd speciation and localization in the hyperaccumulator Arabidopsis halleri. Environ. Exp. Bot. 82: 54-65.

Hutchinson, J. J., Young, S. D., McGrath, S. P., West, H. M., Black, C. R. and Baker, A. J. M. 2000. Determining uptake of 'non-labile' soil cadmium by Thlaspi caerulescens using isotopic dilution techniques. New Phytol. 146: 453-460.

Ishikawa, S., Ishimaru, Y., Igura, M., Kuramata, M., Abe, T., Senoura, T., Hase, Y., Arao, T., Nishizawa, N. K. and Nakanishi, H. 2012. Ion-beam irradiation, gene identification, and marker-assisted breeding in the development of low-cadmium rice. Proc. Natl. Acad. Sci. 109: 19166-19171.

Ishimaru, Y., Suzuki, M., Tsukamoto, T., Suzuki, K., Nakazono, M., Kobayashi, T., Wada, Y., Watanabe, S., Matsuhashi, S., Takahashi, M., Nakanishi, H., Mori, S. and Nishizawa, N. K. 2006. Rice plants take up iron as an $\mathrm{Fe}^{3+}$ phytosiderophore and as $\mathrm{Fe}^{2+}$. Plant J. 45: 335-346.

Ishimaru, Y., Takahashi, R., Bashir, K., Shimo, H., Senoura, T., Sugimoto, K., Ono, K., Yano, M., Ishikawa, S., Arao, T., Nakanishi, H. and Nishizawa, N. K. 2012. Characterizing the role of rice NRAMP5 in manganese, ion and cadmium transport. Sci. Rep. 2: 286.

Jack, E., Hakvoort, H. W. J., Reumer, A., Verkleij, J. A. C., Schat, H. and Ernst, W. H. O. 2007. Real-time PCR analysis of metallothionein-2b expression in metallicolous and 

non-metallicolous populations of Silene vulgaris (Moench) Garcke. Environ. Exp. Bot. 59: 84-91.

Jacquart, A., Brayner, R., El Hage Chahine, J.-M. and Ha-Duong, N.-T. 2017. Cd2+ and Pb2+ complexation by glutathione and the phytochelatins. Chemico-Biol. Interactions 267: $2-10$.

Jarvis, S. C., Jones, L. H. P. and Hopper, M. J. 1976. Cadmium uptake from solution by plants and its transport from roots to shoots. Plant Soil 44: 179-191.

Jiang, R. F., Ma, D. Y., Zhao, F. J. and McGrath, S. P. 2005. Cadmium hyperaccumulation protects Thlaspi caerulescens from leaf feeding damage by thrips (Frankliniella occidentalis). New Phytol. 167: 805-814.

John, M. K. 1973. Cadmium uptake by eight food crops as influenced by various soil levels of cadmium. Environ. Pollut. 4: 7-15.

John, M. K., Chuah, H. H. and VanLaerhoven, C. 1972. Cadmium contamination of soil and its uptake by oats. Environ. Sci. Technol. 6: 555-557.

Jones, D., Nguyen, C. and Finlay, R. 2009. Carbon flow in the rhizosphere: carbon trading at the soil-root interface. Plant Soil.

Kato, M., Ishikawa, S., Inagaki, K., Chiba, K., Hayashi, H., Yanagisawa, S. and Yoneyama, T. 2010. Possible chemical forms of cadmium and varietal differences in cadmium concentrations in the phloem sap of rice plants (Oryza sativa L.). Soil Sci. Plant Nutr. 56: $839-847$.

Kim, D.-Y., Bovet, L., Maeshima, M., Martinoia, E. and Lee, Y. 2007. The ABC transporter AtPDR8 is a cadmium extrusion pump conferring heavy metal resistance. Plant J. 50: 207-218.

Kinraide, T. B. 1998. Three mechanisms for the calcium alleviation of mineral toxicities. Plant Physiol. 118: 513-520. 
Kobayashi, N. I., Tanoi, K., Hirose, A. and Nakanishi, T. M. 2013. Characterization of rapid intervascular transport of cadmium in rice stem by radioisotope imaging. J. Exp. Bot. 64: $507-517$.

Koren'kov, V., Park, S., Cheng, N.-H., Sreevidya, C., Lachmansingh, J., Morris, J., Hirschi, K. and Wagner, G. J. 2007. Enhanced $\mathrm{Cd}^{2+}$-selective root-tonoplast-transport in tobaccos expressing Arabidopsis cation exchanger. Planta 225: 403-411.

Korenkov, V., King, B., Hirschi, K. and Wagner, G. J. 2009. Root-selective expression of AtCAX4 and AtCAX2 results in reduced lamina cadmium in field-grown Nicotiana tabacum L. Plant Biotechnol. J. 7: 219-226.

Korshunova, Y. O., Eide, D., Gregg Clark, W., Lou Guerinot, M. and Pakrasi, H. B. 1999. The IRT1 protein from Arabidopsis thaliana is a metal transporter with a broad substrate range. Plant Mol. Biol. 40: 37-44.

Kupper, H. and Andresen, E. 2016. Mechanisms of metal toxicity in plants. Metallomics.

Küpper, H., Mijovilovitch, A., Meyer-Klaucke, W. and Kroneck, P. M. H. 2004. Tissue- and age-dependant differences in the complexation of cadmium and zinc in the cadmium/zinc hyperaccumulator Thlaspi caerulescens (Ganges ecotype) revealed by X-ray absorption spectroscopy. Plant Physiol. 134: 748-757.

Kuramata, M., Masuya, S., Takahashi, Y., Kitagawa, E., Inoue, C., Ishikawa, S., Youssefi, S. and Kusano, T. 2009. Novel cysteine-rich peptides from Digitaria ciliaris and Oryza sativa enhance tolerance to cadmium by limiting its cellular accumulation. Plant Cell Physiol. 50: 107-117.

Lackovic, K., Angove, M. J., Wells, J. D. and Johnson, B. B. 2004. Modeling the adsorption of Cd(II) onto goethite in the presence of citric acid. J. Colloid Interface Sci. 269: 3745. 
1559

1560

1561

1562

1563

1564

1565

1566

1567

1568

1569

1570

1571

1572

1573

1574

1575

1576

1577

1578

1579

1580

1581

1582

Lagerwerff, J. V. 1971. Uptake of cadmium, lead and zinc by radish from soil and air. Soil Sci. 111: 129-133.

Lane, T. W., Saito, M. A., George, G. N., Pickering, I. J., Prince, R. C. and Morel, F. M. M. 2005. The first cadmium enzyme - carbonic anhydrase 2 from the marine diatom Thalassiosira weissflogii. SSRL Scienc High.

Lanquar, V., Lelièvre, F., Bolte, S., Hamès, C., Alcon, C., Neumann, D., Vansuyt, G., Curie, C., Schröder, A. and Krämer, U. 2005. Mobilization of vacuolar iron by AtNRAMP3 and AtNRAMP4 is essential for seed germination on low iron. EMBO J. 24: 40414051.

Lanquar, V., Ramos, M. S., Lelièvre, F., Barbier-Brygoo, H., Krieger-Liszkay, A., Krämer, U. and Thomine, S. 2010. Export of vacuolar manganese by AtNRAMP3 and AtNRAMP4 is required for optimal photosynthesis and growth under manganese deficiency. Plant Physiol. 152: 1986-1999.

Laporte, M.-A., Denaix, L., Pagès, L., Sterckeman, T., Flénet, F., Dauguet, S. and Nguyen, C. 2013. Longitudinal variation in cadmium influx in intact first order lateral roots of sunflower (Helianthus annuus L). Plant Soil 372: 581-595.

Laporte, M.-A., Sterckeman, T., Dauguet, S., Denaix, L. and Nguyen, C. 2015. Variability in cadmium and zinc shoot concentration in 14 cultivars of sunflower (Helianthus annuus L.) as related to metal uptake and partitioning. Environ. Exp. Bot. 109: 45-53.

Larsson Jönsson, E. H. and Asp, H. 2013. Effects of pH and nitrogen on cadmium uptake in potato. Biol. Plantarum 57: 788-792.

Lee, S., Moon, J. S., Ko, T.-S., Petros, D., Goldsbrough, P. B. and Korban, S. S. 2003. Overexpression of Arabidopsis phytochelatin synthase paradoxically leads to hypersensitivity to cadmium stress. Plant Physiol. 131: 656-663. 
Leitenmaier, B. and Küpper, H. 2011. Cadmium uptake and sequestration kinetics in individual leaf cell protoplasts of the $\mathrm{Cd} / \mathrm{Zn}$ hyperaccumulator Thlaspi caerulescens. Plant Cell Environ. 34: 208-219.

Leopold, I., Günther, D., Schmidt, J. and Neumann, D. 1999. Phytochelatins and heavy metal tolerance. Phytochem. 50: 1323-1328.

Leverrier, P., Montigny, C., Garrigos, M. and Champeil, P. 2007. Metal binding to ligands: Cadmium complexes with glutathione revisited. Anal. Biochem. 371: 215-228.

Li, J.-Y., Fu, Y.-L., Pike, S. M., Bao, J., Tian, W., Zhang, Y., Chen, C.-Z., Zhang, Y., Li, H.M., Huang, J., Li, L.-G., Schroeder, J. I., Gassmann, W. and Gong, J.-M. 2010. The Arabidopsis nitrate transporter NRT1.8 functions in nitrate removal from the xylem sap and mediates cadmium tolerance. Plant Cell 22: 1633-1646.

Li, L., Liu, X., Peijnenburg, W. J. G. M., Zhao, J., Chen, X., Yu, J. and Wu, H. 2012 a. Pathways of cadmium fluxes in the root of the halophyte Suaeda salsa. Ecotoxicol. Environ. Safety 75: 1-7.

Li, S. U. N., Yu, J., Zhu, M., Zhao, F. and Luan, S. 2012b. Cadmium impairs ion homeostasis by altering $\mathrm{K}^{+}$and $\mathrm{Ca}^{2+}$ channel activities in rice root hair cells. Plant Cell Environ. 35: 1998-2013.

Li, T., Tao, Q., Shohag, M., Yang, X., Sparks, D. and Liang, Y. 2015. Root cell wall polysaccharides are involved in cadmium hyperaccumulation in Sedum alfredii. Plant Soil 389: 387-399.

Liang, J., Shohag, M. J. I., Yang, X., Tian, S., Zhang, Y., Feng, Y. and He, Z. 2014. Role of sulfur assimilation pathway in cadmium hyperaccumulation by Sedum alfredii Hance. Ecotoxicol. Environ. Safety 100: 159-165.

Liang, T., Ding, H., Wang, G., Kang, J., Pang, H. and Lv, J. 2016. Sulfur decreases cadmium translocation and enhances cadmium tolerance by promoting sulfur assimilation and 
glutathione metabolism in Brassica chinensis L. Ecotoxicol. Environ. Safety 124: 129137.

Liang, Y., Wong, J. W. C. and Wei, L. 2005. Silicon-mediated enhancement of cadmium tolerance in maize (Zea mays L.) grown in cadmium contaminated soil. Chemosphere 58: $475-483$.

Lin, Y.-F. and Aarts, M. M. 2012. The molecular mechanism of zinc and cadmium stress response in plants. Cell. Mol. Life Sci. 69: 3187-3206.

Lin, Y.-F., Hassan, Z., Talukdar, S., Schat, H. and Aarts, M. G. M. 2016a. Expression of the ZNT1 zinc transporter from the metal hyperaccumulator Noccaea caerulescens confers enhanced zinc and cadmium tolerance and accumulation to Arabidopsis thaliana. PLoS ONE 11: e0149750.

Lin, Z., Schneider, A., Sterckeman, T. and Nguyen, C. 2016b. Ranking of mechanisms governing the phytoavailability of cadmium in agricultural soils using a mechanistic model. Plant Soil 399: 89-107.

Lindberg, S., Landberg, T. and Greger, M. 2007. Cadmium uptake and interaction with phytochelatins in wheat protoplasts. Plant Physiol. Biochem. 45: 47-53.

Liñero, O., Cornu, J.-Y., Candaudap, F., Pokrovsky, O. S., Bussière, S., Coriou, C., HumannGuilleminot, T., Robert, T., Thunot, S., de Diego, A. and Nguyen, C. 2016. Short-term partitioning of Cd recently taken up between sunflowers organs (Helianthus annuus) at flowering and grain filling stages: effect of plant transpiration and allometry. Plant Soil 408: 163-181.

Liñero, O., Cornu, J.-Y., de Diego, A., Bussière, S., Coriou, C., Thunot, S., Robert, T. and Nguyen, C. 2018. Source of Ca, Cd, Cu, Fe, K, Mg, Mn, Mo and $\mathrm{Zn}$ in grains of sunflower (Helianthus annuus) grown in nutrient solution: root uptake or remobilization from vegetative organs? Plant Soil 424: 435-450. 
Liu, H., Zhang, J., Christie, P. and Zhang, F. 2008. Influence of iron plaque on uptake and accumulation of Cd by rice (Oryza sativa L.) seedlings grown in soil. Sc. Total Environ. 394: 361-368.

Liu, H., Zhao, H., Wu, L., Liu, A., Zhao, F.-J. and Xu, W. 2017. Heavy metal ATPase 3 (HMA3) confers cadmium hypertolerance on the cadmium/zinc hyperaccumulator Sedum plumbizincicola. New Phytol. 215: 687-698.

Liu, H. J., Zhang, J. L. and Zhang, F. S. 2007. Role of iron plaque in Cd uptake by and translocation within rice (Oryza sativa L.) seedlings grown in solution culture. Environ. Exp. Bot. 59: 314-320.

Lofts, S. and Tipping, E. 1998. An assemblage model for cation binding by natural particulate matter. Geochim. Cosmochim. Acta 62: 2609-2625.

Lombi, E., Tearall, K. L., Howarth, J. R., Zhao, F.-J., Hawkesford, M. J. and McGrath, S. P. 2002. Influence of iron status on cadmium and zinc uptake by different ecotypes of the hyperaccumulator Thlaspi caerulescens. Plant Physiol. 128: 1359-1367.

Lombi, E., Zhao, F. J., McGrath, S. P., Young, S. D. and Sacchi, G. E. 2001. Physiological evidence for a high-affinity cadmium transporter highly expressed in a Thlaspi caerulescens ecotype. New Phytol. 149: 53-60.

Long, L., Persson, D. P., Duan, F., Jørgensen, K., Yuan, L., Schjoerring, J. K. and Pedas, P. R. 2018. The iron-regulated transporter 1 plays an essential role in uptake, translocation and grain-loading of manganese, but not iron, in barley. New Phytol. 217: $1640-1653$.

Lovy, L., Latt, D. and Sterckeman, T. 2013. Cadmium uptake and partitioning in the hyperaccumulator Noccaea caerulescens exposed to constant $\mathrm{Cd}$ concentrations throughout complete growth cycles. Plant Soil: 345-354. 
Lozano-Rodriguez, E., Hernàndez, L. E., Bonay, P. and Carpena-Ruiz, R. O. 1997. Distribution of cadmium in shoot and root tissues of maize and pea plants. Physiological disturbances. J. Exp. Bot. 48: 123-128.

Luo, B. F., Du, S. T., Lu, K. X., Liu, W. J., Lin, X. Y. and Jin, C. W. 2012. Iron uptake system mediates nitrate-facilitated cadmium accumulation in tomato (Solanum lycopersicum) plants. J. Exp. Bot. 63: 3127-3136.

Luo, J.-S., Huang, J., Zeng, D.-L., Peng, J.-S., Zhang, G.-B., Ma, H.-L., Guan, Y., Yi, H.-Y., Fu, Y.-L., Han, B., Lin, H.-X., Qian, Q. and Gong, J.-M. 2018. A defensin-like protein drives cadmium efflux and allocation in rice. Nature Communications 9: 645.

Lux, A., Martinka, M., Vaculik, M. and White, P. J. 2011. Root responses to cadmium in the rhizosphere: a review. J. Exp. Bot. 62: 21-37.

Maccaferri, M., Harris, N. S., Twardziok, S. O., Pasam, R. K., Gundlach, H., Spannagl, M., Ormanbekova, D., Lux, T., Prade, V. M., Milner, S. G., Himmelbach, A., Mascher, M., Bagnaresi, P., Faccioli, P., Cozzi, P., Lauria, M., Lazzari, B., Stella, A., Manconi, A., Gnocchi, M., Moscatelli, M., Avni, R., Deek, J., Biyiklioglu, S., Frascaroli, E., Corneti, S., Salvi, S., Sonnante, G., Desiderio, F., Marè, C., Crosatti, C., Mica, E., Özkan, H., Kilian, B., De Vita, P., Marone, D., Joukhadar, R., Mazzucotelli, E., Nigro, D., Gadaleta, A., Chao, S., Faris, J. D., Melo, A. T. O., Pumphrey, M., Pecchioni, N., Milanesi, L., Wiebe, K., Ens, J., MacLachlan, R. P., Clarke, J. M., Sharpe, A. G., Koh, C. S., Liang, K. Y. H., Taylor, G. J., Knox, R., Budak, H., Mastrangelo, A. M., Xu, S. S., Stein, N., Hale, I., Distelfeld, A., Hayden, M. J., Tuberosa, R., Walkowiak, S., Mayer, K. F. X., Ceriotti, A., Pozniak, C. J. and Cattivelli, L. 2019. Durum wheat genome highlights past domestication signatures and future improvement targets. Nature Genetics 51: 885-895. 
Mah, V. and Jalilehvand, F. 2010. Cadmium(II) complex formation with glutathione. J. Biol. Inorg. Chem. 15: 441-458.

Marentes, E. and Rauser, W. E. 2007. Different proportions of cadmium occur as Cd-binding phytochelatin complexes in plants. Physiol. Plant. 131: 291-301.

Martin-Garin, A., Van Cappellen, P. and Charlet, L. 2003. Aqueous cadmium uptake by calcite: A stirred flow-through reactor study. Geochim. Cosmochim. Acta 67: 27632774.

Maxted, A. P., Black, C. R., West, H. M., Crout, N. M. J., McGrath, S. P. and Young, S. D. 2007. Phytoextraction of cadmium and zinc from arable soils amended with sewage sludge using Thlaspi caerulescens: Development of a predictive model. Environ. Pollut. 150: 363-372.

McLaughlin, M. J., Andrew, S. J., Smart, M. K. and Smolders, E. 1998a. Effects of sulfate on cadmium uptake by Swiss chard: I. Effects of complexation and calcium competition in nutrient solutions. Plant Soil 202: 211-216.

McLaughlin, M. J., Lambrechts, R. M., Smolders, E. and Smart, M. K. 1998b. Effects of sulfate on cadmium uptake by Swiss chard: II. Effects due to sulfate addition to soil. Plant Soil 202: 217-222.

McLaughlin, M. J., Tiller, K. G. and Smart, M. K. 1997. Speciation of cadmium in soil soilutions of saline/sodic soils and relationship with cadmium concentrations in potato tubers (Solanum tuberosum L.). Aust. J. Soil Res. 35: 183-198.

Meda, A. R., Scheuermann, E. B., Prechsl, U. E., Erenoglu, B., Schaaf, G., Hayen, H., Weber, G. and von Wirén, N. 2007. Iron acquisition by phytosiderophores contributes to cadmium tolerance. Plant Physiol. 143: 1761-1773.

Mendoza-Cozatl, D. G., Butko, E., Springer, F., Torpey, J. W., Komives, E. A., Kehr, J. and Schroeder, J. I. 2008. Identification of high levels of phytochelatins, glutathione and 

cadmium in the phloem sap of Brassica napus. A role for thiol-peptides in the longdistance transport of cadmium and the effect of cadmium on iron translocation. Plant J. 54: 249-259.

Mengoni, A., Gonnelli, C., Hakvoort, H. W. J., Galardi, F., Bazzicalupo, M., Gabbrielli, R. and Schat, H. 2003. Evolution of copper-tolerance and increased expression of a 2btype metallothionein gene in Silene paradoxa L. populations. Plant Soil 257: 451-457.

Meyer, C.-L., Juraniec, M., Huguet, S., Chaves-Rodriguez, E., Salis, P., Isaure, M.-P., Goormaghtigh, E. and Verbruggen, N. 2015. Intraspecific variability of cadmium tolerance and accumulation, and cadmium-induced cell wall modifications in the metal hyperaccumulator Arabidopsis halleri. J. Exp. Bot. 66: 3215-3227.

Migocka, M., Papierniak, A., Kosieradzka, A., Posyniak, E., Maciaszczyk-Dziubinska, E., Biskup, R., Garbiec, A. and Marchewka, T. 2015. Cucumber metal tolerance protein CsMTP9 is a plasma membrane $\mathrm{H}^{+}$-coupled antiporter involved in the $\mathrm{Mn}^{2+}$ and $\mathrm{Cd}^{2+}$ efflux from root cells. Plant J. 84: 1045-1058.

Mills, R. F., Francini, A., Ferreira da Rocha, P. S. C., Baccarini, P. J., Aylett, M., Krijger, G. C. and Williams, L. E. 2005. The plant P1B-type ATPase AtHMA4 transports Zn and $\mathrm{Cd}$ and plays a role in detoxification of transition metals supplied at elevated levels. FEBS Lett. 579: 783-791.

Mills, R. F., Krijger, G. C., Baccarini, P. J., Hall, J. L. and Williams, L. E. 2003. Functional expression of AtHMA4, a P1B-type ATPase of the $\mathrm{Zn} / \mathrm{Co} / \mathrm{Cd} / \mathrm{Pb}$ subclass. Plant J. 35: $164-176$.

Milner, M. J., Craft, E., Yamaji, N., Koyama, E., Ma, J. F. and Kochian, L. V. 2012. Characterization of the high affinity $\mathrm{Zn}$ transporter from Noccaea caerulescens, NcZNT1, and dissection of its promoter for its role in Zn uptake and hyperaccumulation. New Phytol. 195: 113-123. 
Mirouze, M., Sels, J., Richard, O., Czernic, P., Loubet, S., Jacquier, A., François, I. E. J. A., Cammue, B. P. A., Lebrun, M., Berthomieu, P. and Marquès, L. 2006. A putative novel role for plant defensins: a defensin from the zinc hyper-accumulating plant, Arabidopsis halleri, confers zinc tolerance. Plant J. 47: 329-342.

Mishra, S., Mishra, A. and Küpper, H. 2017. Protein biochemistry and expression regulation of cadmium/zinc pumping ATPases in the hyperaccumulator plants Arabidopsis halleri and Noccaea caerulescens. Frontiers Plant Sci. 8.

Misono, M., Ochiai, E., Saito, Y. and Yoneda, Y. 1967. A new dual parameter scale for the strength of lewis acids and bases with the evaluation of their softness. Journal of Inorganic and Nuclear Chemistry 29: 2685-2691.

Miyadate, H., Adachi, S., Hiraizumi, A., Tezuka, K., Nakazawa, N., Kawamoto, T., Katou, K., Kodama, I., Sakurai, K., Takahashi, H., Satoh-Nagasawa, N., Watanabe, A., Fujimura, T. and Akagi, H. 2011. OsHMA3, a P1B-type of ATPase affects root-toshoot cadmium translocation in rice by mediating efflux into vacuoles. New Phytol. 189: 190-199.

Monsant, A., Wang, Y. and Tang, C. 2010. Nitrate nutrition enhances zinc hyperaccumulation in Noccaea caerulescens (Prayon). Plant Soil 336: 391-404.

Morel, M., Crouzet, J., Gravot, A., Auroy, P., Leonhardt, N., Vavasseur, A. and Richaud, P. 2009. AtHMA3, a P1B-ATPase allowing $\mathrm{Cd} / \mathrm{Zn} / \mathrm{Co} / \mathrm{Pb}$ vacuolar storage in Arabidopsis. Plant Physiol. 149: 894-904.

Moulis, J.-M. 2010. Cellular mechanisms of cadmium toxicity related to the homeostasis of essential metals. BioMetals 23: 877-896.

Naidu, R. and Harter, R. D. 1998. Effect of different organic ligands on cadmium sorption by extractability from soils. Soil Sci. Soc. Am. J. 62: 644-650. 
Nakamura, S.-i., Suzui, N., Nagasaka, T., Komatsu, F., Ishioka, N. S., Ito-Tanabata, S., Kawachi, N., Rai, H., Hattori, H., Chino, M. and Fujimaki, S. 2013. Application of glutathione to roots selectively inhibits cadmium transport from roots to shoots in oilseed rape. J. Exp. Bot. 64: 1073-1081.

Nakanishi, H., Ogawa, I., Ishimaru, Y., Mori, S. and Nishizawa, N. K. 2006. Iron deficiency enhances cadmium uptake and translocation mediated by the $\mathrm{Fe}^{2+}$ transporters OsIRT1 and OsIRT2 in rice. Soil Sci. Plant Nutr. 52: 464-469.

Nocito, F. F., Lancilli, C., Dendena, B., Lucchini, G. and Sacchi, G. A. 2011. Cadmium retention in rice roots is influenced by cadmium availability, chelation and translocation. Plant Cell Environ. 34: 994-1008.

Nocito, F. F., Pirovano, L., Cocucci, M. and Sacchi, G. A. 2002. Cadmium-induced sulfate uptake in maize roots. Plant Physiol. 129: 1872-1879.

Nolan, A. L., McLaughlin, M. J. and Mason, S. D. 2003. Chemical speciation of Zn, Cd, Cu, and $\mathrm{Pb}$ in pore waters of agricultural and contaminated soils using Donnan dialysis. Environ. Sci. Technol. 37: 90-98.

Nowack, B., Schulin, R. and Robinson, B. H. 2006. Critical assessment of chelant-enhanced metal phytoextraction. Environ. Sci. Technol. 40: 5225-5232.

Nwugo, C. C. and Huerta, A. J. 2008. Silicon-induced cadmium resistance in rice (Oryza sativa). J. Plant Nutr. Soil Sci. 171: 841-848.

Ó Lochlainn, S., Bowen, H. C., Fray, R. G., Hammond, J. P., King, G. J., White, P. J., Graham, N. S. and Broadley, M. R. 2011. Tandem Quadruplication of HMA4 in the Zinc (Zn) and Cadmium (Cd) Hyperaccumulator Noccaea caerulescens. PLoS ONE 6: e17814.

Oomen, R. J. F. J., Wu, J., Lelièvre, F., Blanchet, S., Richaud, P., Barbier-Brygoo, H., Aarts, M. G. M. and Thomine, S. 2009. Functional characterization of NRAMP3 and 
NRAMP4 from the metal hyperaccumulator Thlaspi caerulescens. New Phytol. 181: 637-650.

Panfili, F., Schneider, A., Vives, A., Perrot, F., Hubert, P. and Pellerin, S. 2009. Cadmium uptake by durum wheat in presence of citrate. Plant Soil 316: 299-309.

Papoyan, A. and Kochian, L. V. 2004. Identification of Thlaspi caerulescens genes that may be involved in heavy metal hyperaccumulation and tolerance. Characterization of a novel heavy metal transporting ATPase. Plant Physiol. 136: 3814-3823.

Park, J., Song, W.-Y., Ko, D., Eom, Y., Hansen, T. H., Schiller, M., Lee, T. G., Martinoia, E. and Lee, Y. 2012. The phytochelatin transporters AtABCC1 and AtABCC2 mediate tolerance to cadmium and mercury. Plant J. 69: 278-288.

Pedas, P., Ytting, C. K., Fuglsang, A. T., Jahn, T. P., Schjoerring, J. K. and Husted, S. 2008. Manganese efficiency in barley: Identification and characterization of the metal ion transporter HvIRT1. Plant Physiol. 148: 455-466.

Pence, N. S., Larsen, P. B., Ebbs, S. D., Letham, D. L. D., Lasat, M. M., Garvin, D. F., Eide, D. and Kochian, L. V. 2000. The molecular physiology of heavy metal transport in the Zn/Cd hyperaccumulator Thlaspi caerulescens. Proc. Natl. Acad. Sci. U.S.A. 97: 4956-4960.

Peng, F., Wang, C., Zhu, J., Zeng, J., Kang, H., Fan, X., Sha, L., Zhang, H., Zhou, Y. and Wang, Y. 2018. Expression of TpNRAMP5, a metal transporter from Polish wheat (Triticum polonicum L.), enhances the accumulation of $\mathrm{Cd}$, Co and $\mathrm{Mn}$ in transgenic Arabidopsis plants. Planta 247: 1395-1406.

Peng, J.-S., Ding, G., Meng, S., Yi, H.-Y. and Gong, J.-M. 2017a. Enhanced metal tolerance correlates with heterotypic variation in SpMTL, a metallothionein-like protein from the hyperaccumulator Sedum plumbizincicola. Plant Cell Environ. 40: 1368-1378. 
Peng, J.-S., Wang, Y.-J., Ding, G., Ma, H.-L., Zhang, Y.-J. and Gong, J.-M. 2017b. A pivotal role of cell wall in cadmium accumulation in the Crassulaceae hyperaccumulator Sedum plumbizincicola. Molecular Plant 10: 771-774.

Perfus-Barbeoch, L., Leonhardt, N., Vavasseur, A. and Forestier, C. 2002. Heavy metal toxicity: cadmium permeates through calcium channels and disturbs the plant water status. Plant J. 32: 539-548.

Perriguey, J., Sterckeman, T. and Morel, J.-L. 2008. Effect of rhizosphere and plant-related factors on the cadmium uptake by maize (Zea mays L.). Environ. Exp. Bot. 63: 333341.

Persson, D. P., Hansen, T. H., Holm, P. E., Schjoerring, J. K., Hansen, H. C. B., Nielsen, J., Cakmak, I. and Husted, S. 2006. Multi-elemental speciation analysis of barley genotypes differing in tolerance to cadmium toxicity using SEC-ICP-MS and ESITOF-MS. J. Anal. Atom. Spectr. 21: 996-1005.

Pineros, M. A., Shaff, J. E. and Kochian, L. V. 1998. Development, characterization, and application of a cadmium-selective microelectrode for the measurement of cadmium fluxes in roots of Thlaspi species and wheat. Plant Physiol. 116: 1393-1401.

Pinto, A. P., Simes, I. and Mota, A. M. 2008. Cadmium impact on root exudates of sorghum and maize plants: A speciation study. J. Plant Nutr. 31: 1746-1755.

Pittman, J. K., Shigaki, T., Marshall, J. L., Morris, J. L., Cheng, N.-H. and Hirschi, K. D. 2004. Functional and regulatory analysis of the Arabidopsis thaliana CAX2 cation transporter. Plant Mol. Biol. 56: 959-971.

Plaza, S., Tearall, K. L., Zhao, F.-J., Buchner, P., McGrath, S. P. and Hawkesford, M. J. 2007. Expression and functional analysis of metal transporter genes in two contrasting ecotypes of the hyperaccumulator Thlaspi caerulescens. J. Exp. Bot. 58: 1717-1728. 
Plaza, S., Weber, J., Pajonk, S., Thomas, J., Talke, I., Schellenberg, M., Pradervand, S., Burla, B., Geisler, M., Martinoia, E. and Krämer, U. 2015. Wounding of Arabidopsis halleri leaves enhances cadmium accumulation that acts as a defense against herbivory. BioMetals: 1-8.

Pongrac, P., Serra, T. S., Castillo-Michel, H., Vogel-Mikuš, K., Arčon, I., Kelemen, M., Jenčič, B., Kavčič, A., Villafort Carvalho, M. T. and Aarts, M. G. M. 2018. Cadmium associates with oxalate in calcium oxalate crystals and competes with calcium for translocation to stems in the cadmium bioindicator Gomphrena claussenii. Metallomics 10: 1576-1584.

Pottier, M., Oomen, R., Picco, C., Giraudat, J., Scholz-Starke, J., Richaud, P., Carpaneto, A. and Thomine, S. 2015. Identification of mutations allowing Natural Resistance Associated Macrophage Proteins (NRAMP) to discriminate against cadmium. Plant J. 83: $625-637$.

Ptashnyk, M., Roose, T., Jones, D. L. and Kirk, G. J. D. 2011. Enhanced zinc uptake by rice through phytosiderophore secretion: a modelling study. Plant Cell Environ. 34: 20382046.

Puschenreiter, M., Gruber, B., Wenzel, W. W., Schindlegger, Y., Hann, S., Spangl, B., Schenkeveld, W. D. C., Kraemer, S. M. and Oburger, E. 2017. Phytosiderophoreinduced mobilization and uptake of $\mathrm{Cd}, \mathrm{Cu}, \mathrm{Fe}, \mathrm{Ni}, \mathrm{Pb}$ and $\mathrm{Zn}$ by wheat plants grown on metal-enriched soils. Environ. Exp. Bot. 138: 67-76.

Qaswar, M., Hussain, S. and Rengel, Z. 2017. Zinc fertilisation increases grain zinc and reduces grain lead and cadmium concentrations more in zinc-biofortified than standard wheat cultivar. Sc. Total Environ. 605-606: 454-460. 
Qin, Q., Li, X., Wu, H., Zhang, Y., Feng, Q. and Tai, P. 2013. Characterization of cadmium $\left({ }^{108} \mathrm{Cd}\right)$ distribution and accumulation in Tagetes erecta L. seedlings: Effect of splitroot and of remove-xylem/phloem. Chemosphere 93: 2284-2288.

Qin, Q., Li, X., Zhuang, J., Weng, L., Liu, W. and Tai, P. 2015. Long-distance transport of cadmium from roots to leaves of Solanum melongena. Ecotoxicol. 24: 2224-2232.

Rahman, M. F., Ghosal, A., Alam, M. F. and Kabir, A. H. 2017. Remediation of cadmium toxicity in field peas (Pisum sativum L.) through exogenous silicon. Ecotoxicol. Environ. Safety 135: 165-172.

Rauser, W. E. 1995. Phytochelatins and related peptides. Structure, biosynthesis, and function. Plant Physiol. 109: 1141-1149.

Rauser, W. E. 2003. Phytochelatin-based complexes bind various amounts of cadmium in maize seedlings depending on the time of exposure, the concentration of cadmium and the tissue. New Phytol. 158: 269-278.

Redjala, T. 2009. Etude de l'absorption racinaire du cadmium afin d'améliorer la modélisation de son transfert vers la plante. Ecole Nationale d'Agronomie et des Industries Alimentaires. Nancy Université, Vandoeuvre-lès-Nancy.

Redjala, T., Sterckeman, T. and Morel, J. L. 2009. Cadmium uptake by roots: Contribution of apoplast and of high- and low-affinity membrane transport systems. Environ. Exp. Bot. 67: $235-242$.

Redjala, T., Sterckeman, T. and Morel, J. L. 2010a. Determination of the different components of cadmium short-term uptake by roots. J. Plant Nutr. Soil Sci. 173: 935945.

Redjala, T., Sterckeman, T., Skiker, S. and Echevarria, G. 2010b. Contribution of apoplast and symplast to short term nickel uptake by maize and Leptoplax emarginata roots. Environ. Exp. Bot. 68: 99-106. 
Redjala, T., Zelko, I., Sterckeman, T., Legué, V. and Lux, A. 2011. Relationship between root structure and root cadmium uptake in maize. Environ. Exp. Bot. 71: 241-248.

Ren, Y., Liu, Y., Chen, H., Li, G., Zhang, X. and Zhao, J. I. E. 2012. Type 4 metallothionein genes are involved in regulating $\mathrm{Zn}$ ion accumulation in late embryo and in controlling early seedling growth in Arabidopsis. Plant Cell Environ. 35: 770-789.

Ren, Z.-L., Tella, M., Bravin, M. N., Comans, R. N. J., Dai, J., Garnier, J.-M., Sivry, Y., Doelsch, E., Straathof, A. and Benedetti, M. F. 2015a. Effect of dissolved organic matter composition on metal speciation in soil solutions. Chem. Geol. 398: 61-69.

Ren, Z. L., Sivry, Y., Dai, J., Tharaud, M., Cordier, L. and Benedetti, M. F. 2015b. Multielement stable isotopic dilution and multi-surface modelling to assess the speciation and reactivity of cadmium and copper in soil. Eur. J. Soil Sci. 66: 973-982.

Rodriguez-Hernandez, M. C., Bonifas, I., Alfaro-De la Torre, M. C., Flores-Flores, J. L., Bañuelos-Hernández, B. and Patiño-Rodríguez, O. 2015. Increased accumulation of cadmium and lead under $\mathrm{Ca}$ and Fe deficiency in Typha latifolia: A study of two pore channel (TPC1) gene responses. Environ. Exp. Bot. 115: 38-48.

Roosens, N., Leplae, R., Bernard, C. and Verbruggen, N. 2005. Variations in plant metallothioneins: the heavy metal hyperaccumulator Thlaspi caerulescens as a study case. Planta 222: 716-729.

Saifullah, Javed, H., Naeem, A., Rengel, Z. and Dahlawi, S. 2016. Timing of foliar Zn application plays a vital role in minimizing $\mathrm{Cd}$ accumulation in wheat. Environ. Sci. Pollut. Res. 23: 16432-16439.

Salt, D. E., Pickering, I. J., Prince, R. C., Gleba, D., Dushenkov, S., Smith, R. D. and Raskin, I. 1997. Metal accumulation by aquacultured seedlings of Indian mustard. Environ. Sci. Technol. 31: 1636-1644. 
Salt, D. E., Prince, R. C., Pickering, I. J. and Raskin, I. 1995. Mechanisms of cadmium mobility and accumulation in Indian Mustard. Plant Physiol. 109: 1427-1433.

Salt, D. E. and Wagner, G. J. 1993. Cadmium transport across tonoplast of vesicles from oat roots. Evidence for a $\mathrm{Cd}^{2+} / \mathrm{H}^{+}$antiport activity. J. Biol. Chem. 268: 12297-12302.

Sarret, G., Vangronsveld, J., Manceau, A., Musso, M., D'Haen, J., Menthonnex, J.-J. and Hazemann, J.-L. 2001. Accumulation forms of $\mathrm{Zn}$ and $\mathrm{Pb}$ in Phaseolus vulgaris in the presence and absence of EDTA. Environ. Sci. Technol. 35: 2854-2859.

Sasaki, A., Yamaji, N., Yokosho, K. and Ma, J. F. 2012. Nramp5 is a major transporter responsible for manganese and cadmium uptake in rice. Plant Cell 24: 2155-2167.

Satoh-Nagasawa, N., Mori, M., Nakazawa, N., Kawamoto, T., Nagato, Y., Sakurai, K., Takahashi, H., Watanabe, A. and Akagi, H. 2012. Mutations in rice (Oryza sativa) Heavy Metal ATPase 2 (OsHMA2) restrict the translocation of zinc and cadmium. Plant Cell Physiol. 53: 213-224.

Sauvé, S., Hendershot, W. and Allen, H. E. 2000a. Solid-solution partitioning of metals in contaminated soils: Dependence on $\mathrm{pH}$, total metal burden, and organic matter. Environ. Sci. Technol. 34: 1125-1131.

Sauvé, S., Norvell, W. A., McBride, M. and Hendershot, W. 2000b. Speciation and complexation of cadmium in extracted soil solutions. Environ. Sci. Technol. 34: 291296.

Schaider, L., Parker, D. and Sedlak, D. 2006. Uptake of EDTA-complexed Pb, Cd and Fe by solution- and sand-cultured Brassica juncea. Plant Soil 286: 377-391.

Schat, H., Llugany, M., Vooijs, R., Hartley-Whitaker, J. and Bleeker, P. M. 2002. The role of phytochelatins in constitutive and adaptive heavy metal tolerances in hyperaccumulator and non-hyperaccumulator metallophytes. J. Exp. Bot. 53: 23812392. 
Schneider, A. 2008. An exchange method to investigate the kinetics of Cd complexation in soil solutions. Environ. Sci. Technol. 42: 4076-4082.

Schneider, A. and Nguyen, C. 2011. Use of an exchange method to estimate the association and dissociation rate constants of cadmium complexes formed with low-molecularweight organic acids commonly exuded by plant roots. J. Environ. Quality 40: 18571862.

Schneider, T., Schellenberg, M., Meyer, S., Keller, F., Gehrig, P., Riedel, K., Lee, Y., Eberl, L. and Martinoia, E. 2009. Quantitative detection of changes in the leaf-mesophyll tonoplast proteome in dependency of a cadmium exposure of barley (Hordeum vulgare L.) plants. Proteomics 9: 2668-2677.

Sebastian, A. and Prasad, M. N. V. 2016. Iron plaque decreases cadmium accumulation in Oryza sativa L. and serves as a source of iron. Plant Biol. 18: 1008-1015.

Senden, M., van der Meer, A., Verburg, T. and Wolterbeek, H. 1995. Citric acid in tomato plant roots and its effect on cadmium uptake and distribution. Plant Soil 171: 333-339.

Shabala, S. 2007. Transport from root to shoot. In: Yeo, A. R. and Flowers, T. J. (eds) Plant Solute Transport. Blackwell Publishing, Oxford.

Shao, J. F., Che, J., Yamaji, N., Shen, R. F. and Ma, J. F. 2017. Silicon reduces cadmium accumulation by suppressing expression of transporter genes involved in cadmium uptake and translocation in rice. J. Exp. Bot. 68: 5641-5651.

Shao, J. F., Xia, J., Yamaji, N., Shen, R. F. and Ma, J. F. 2018. Effective reduction of cadmium accumulation in rice grain by expressing OsHMA3 under the control of the OsHMA2 promoter. J. Exp. Bot. 69: 2743-2752.

Shen, G.-m., Du, Q.-Z. and Wang, J.-x. 2012. Involvement of plasma membrane $\mathrm{Ca}^{2+} / \mathrm{H}^{+}$ antiporter in $\mathrm{Cd}^{2+}$ tolerance. Rice Science 19: 161-165. 
Shenker, M., Fan, T. W.-M. and Crowley, D. E. 2001. Phytosiderophores influence on cadmium mobilization and uptake by wheat and barley plants. J. Environ. Quality 30: 2091-2098.

Shigaki, T. and Hirschi, K. D. 2006. Diverse functions and molecular properties emerging for CAX Cation/H+ exchangers in plants. Plant Biol. 8: 419-429.

Shojima, S., Nishizawa, N.-K., Fushiya, S., Nozoe, S., Irifune, T. and Mori, S. 1990. Biosynthesis of phytosiderophores. In vitro biosynthesis of 2'-deoxymugineic acid from L-methionine and nicotianamine. Plant Physiol. 93: 1497-1503.

Six, L. and Smolders, E. 2014. Future trends in soil cadmium concentration under current cadmium fluxes to European agricultural soils. Sc. Total Environ. 485-486: 319-328.

Smolders, E., Brans, K., Földi, A. and Merckx, R. 1999. Cadmium fixation in soils measured by isotopic dilution. Soil Sci. Soc. Am. J. 63: 78-85.

Smolders, E. and McLaughlin, M. J. 1996a. Chloride increases cadmium uptake in swiss chard in a resin-buffered nutrient solution. Soil Sci. Soc. Am. J. 60: 1443-1447.

Smolders, E. and McLaughlin, M. J. 1996b. Effect of Cl on Cd uptake by Swiss chard in nutrient solutions. Plant Soil 179: 57-64.

Song, W.-Y., Choi, K. S., Kim, D. Y., Geisler, M., Park, J., Vincenzetti, V., Schellenberg, M., Kim, S. H., Lim, Y. P., Noh, E. W., Lee, Y. and Martinoia, E. 2010. Arabidopsis PCR2 is a zinc exporter involved in both zinc extrusion and long-distance zinc transport. Plant Cell 22: 2237-2252.

Song, W.-Y., Martinoia, E., Lee, J., Kim, D., Kim, D.-Y., Vogt, E., Shim, D., Choi, K. S., Hwang, I. and Lee, Y. 2004. A novel family of cys-rich membrane proteins mediates cadmium resistance in Arabidopsis. Plant Physiol. 135: 1027-1039.

Song, W.-Y., Mendoza-CÓZatl, D. G., Lee, Y., Schroeder, J. I., Ahn, S.-N., Lee, H.-S., Wicker, T. and Martinoia, E. 2014. Phytochelatin-metal(loid) transport into vacuoles 
shows different substrate preferences in barley and Arabidopsis. Plant Cell Environ. 37: 1192-1201.

Sposito, G. 1989. The chemistry of soils. Oxford University Press, Oxford.

Sterckeman, T., Carignan, J., Srayeddin, I., Baize, D. and Cloquet, C. 2009. Availability of soil cadmium using stable and radioactive isotope dilution. Geoderma 153: 372-378.

Sterckeman, T., Cazes, Y., Gonneau, C. and Sirguey, C. 2017. Phenotyping 60 populations of Noccaea caerulescens provides a broader knowledge of variation in traits of interest for phytoextraction. Plant Soil 418: 523-540.

Sterckeman, T., Duquene, L., Perriguey, J. and Morel, J. L. 2005. Quantifying the effect of rhizosphere processes on the availability of soil cadmium and zinc. Plant Soil 276: $335-345$.

Sterckeman, T., Gossiaux, L., Guimont, S., Sirguey, C. and Lin, Z. 2018. Cadmium mass balance in French soils under annual crops: Scenarios for the next century. Sc. Total Environ. 639: 1440-1452.

Sterckeman, T. and Puschenreiter, M. 2018. Phytoextraction of Cadmium: Feasibility in Field Applications and Potential Use of Harvested Biomass. In: Van der Ent, A., Echevarria, G., Baker, A. J. M. and Morel, J. L. (eds) Agromining: Farming for Metals: Extracting Unconventional Resources Using Plants. Springer International Publishing, Cham.

Sterckeman, T., Redjala, T. and Morel, J. L. 2011. Influence of exposure solution composition and of plant cadmium content on root cadmium short-term uptake. Environ. Exp. Bot. 74: 131-139.

Sui, F.-Q., Chang, J.-D., Tang, Z., Liu, W.-J., Huang, X.-Y. and Zhao, F.-J. 2018. Nramp5 expression and functionality likely explain higher cadmium uptake in rice than in wheat and maize. Plant Soil 433: 377-389. 
Sui, F., Zhao, D., Zhu, H., Gong, Y., Tang, Z., Huang, X.-Y., Zhang, G. and Zhao, F.-J. 2019. Map-based cloning of a new total loss-of-function allele of OsHMA3 causes high cadmium accumulation in rice grain. J. Exp. Bot. 70: 2857-2871.

Sun, C., Yang, M., Li, Y., Tian, J., Zhang, Y., Liang, L., Liu, Z., Chen, K., Li, Y., Lv, K. and Lian, X. 2019. Comprehensive analysis of variation of cadmium accumulation in rice and detection of a new weak allele of OsHMA3. J. Exp. Bot. 70: 6389-6400.

Sun, Q., Ye, Z. H., Wang, X. R. and Wong, M. H. 2007a. Cadmium hyperaccumulation leads to an increase of glutathione rather than phytochelatins in the cadmium hyperaccumulator Sedum alfredii. J. Plant Physiol. 164: 1489-1498.

Sun, R.-L., Zhou, Q.-X., Sun, F.-H. and Jin, C.-X. 2007b. Antioxidative defense and proline/phytochelatin accumulation in a newly discovered Cd-hyperaccumulator, Solanum nigrum L. Environ. Exp. Bot. 60: 468-476.

Takahashi, R., Ishimaru, Y., Senoura, T., Shimo, H., Ishikawa, S., Arao, T., Nakanishi, H. and Nishizawa, N. K. 2011. The OsNRAMP1 iron transporter is involved in Cd accumulation in rice. J. Exp. Bot. 62: 4843-4850.

Takahashi, R., Ishimaru, Y., Shimo, H., Ogo, Y., Senoura, T., Nishizawa, N. K. and Nakanishi, H. 2012. The OsHMA2 transporter is involved in root-to-shoot translocation of Zn and Cd in rice. Plant Cell Environ. 35: 1948-1957.

Tanaka, K., Fujimaki, S., Fujiwara, T., Yoneyama, T. and Hayashi, H. 2007. Quantitative estimation of the contribution of the phloem in cadmium transport to grains in rice plants (Oryza sativa L.). Soil Sci. Plant Nutr. 53: 72-77.

Tanaka, N., Nishida, S., Kamiya, T. and Fujiwara, T. 2016. Large-scale profiling of brown rice ionome in an ethyl methanesulphonate-mutagenized hitomebore population and identification of high- and low-cadmium lines. Plant Soil 407: 109-117. 
Tang, L., Mao, B., Li, Y., Lv, Q., Zhang, L., Chen, C., He, H., Wang, W., Zeng, X., Shao, Y., Pan, Y., Hu, Y., Peng, Y., Fu, X., Li, H., Xia, S. and Zhao, B. 2017. Knockout of OsNramp5 using the CRISPR/Cas9 system produces low Cd-accumulating indica rice without compromising yield. Sci. Rep. 7: 14438.

Tao, Q., Hou, D., Yang, X. and Li, T. 2015. Oxalate secretion from the root apex of Sedum alfredii contributes to hyperaccumulation of Cd. Plant Soil 398: 139-152.

Tao, Q., Jupa, R., Luo, J., Lux, A., Kováč, J., Wen, Y., Zhou, Y., Jan, J., Liang, Y. and Li, T. 2017. The apoplasmic pathway via the root apex and lateral roots contributes to $\mathrm{Cd}$ hyperaccumulation in the hyperaccumulator Sedum alfredii. J. Exp. Bot. 68: 739-751.

Thomine, S., Lelièvre, F., Debarbieux, E., Schroeder, J. I. and Barbier-Brygoo, H. 2003. AtNRAMP3, a multispecific vacuolar metal transporter involved in plant responses to iron deficiency. Plant J. 34: 685-695.

Thomine, S., Wang, R., Ward, J. M., Crawford, N. M. and Schroeder, J. I. 2000. Cadmium and iron transport by members of a plant metal transporter family in Arabidopsis with homology to Nramp genes. Proc. Natl. Acad. Sci. U.S.A. 97: 4991-4996.

Tian, S., Lu, L., Labavitch, J., Yang, X., He, Z., Hu, H., Sarangi, R., Newville, M., Commisso, J. and Brown, P. 2011. Cellular sequestration of cadmium in the hyperaccumulator plant species Sedum alfredii. Plant Physiol. 157: 1914-1925.

Tian, S., Xie, R., Wang, H., Hu, Y., Ge, J., Liao, X., Gao, X., Brown, P., Lin, X. and Lu, L. 2016. Calcium deficiency triggers phloem remobilization of cadmium in a hyperaccumulating species. Plant Physiol. 172: 2300-2313.

Tian, S., Xie, R., Wang, H., Hu, Y., Hou, D., Liao, X., Brown, P. H., Yang, H., Lin, X., Labavitch, J. M. and Lu, L. 2017. Uptake, sequestration and tolerance of cadmium at cellular levels in the hyperaccumulator plant species Sedum alfredii. J. Exp. Bot. 68: $2387-2398$. 
Tipping, E. 1998. Humic ion-binding model VI: An improved description of the interactions of protons and metal ions with humic substances. Aquatic Geochem. 4: 3-47.

Tommasini, R., Vogt, E., Fromenteau, M., Hörtensteiner, S., Matile, P., Amrhein, N. and Martinoia, E. 1998. An ABC-transporter of Arabidopsis thaliana has both glutathioneconjugate and chlorophyll catabolite transport activity. Plant J. 13: 773-780.

Tye, A. M., Young, S. D., Crout, N. M. J., Zhang, H., Preston, S., Barbosa-Jefferson, V. L., Davison, W., McGrath, S. P., Paton, G. I., Kilham, K. and Resende, L. 2003. Predicting the activity of $\mathrm{Cd}^{2+}$ and $\mathrm{Zn}^{2+}$ in soil pore water from the radio-labile metal fraction. Geochim. Cosmochim. Acta 67: 375-385.

Ueno, D., Iwashita, T., Zhao, F.-J. and Ma, J. F. 2008. Characterization of Cd translocation and identification of the $\mathrm{Cd}$ form in xylem sap of the Cd-hyperaccumulator Arabidopsis halleri. Plant Cell Physiol. 49: 540-548.

Ueno, D., Koyama, E., Yamaji, N. and Ma, J. F. 2011a. Physiological, genetic, and molecular characterization of a high-Cd-accumulating rice cultivar, Jarjan. J. Exp. Bot. 62: 22652272.

Ueno, D., Ma, J. F., Iwashita, T., Zhao, F.-J. and McGrath, S. P. 2005. Identification of the form of $\mathrm{Cd}$ in the leaves of a superior Cd-accumulating ecotype of Thlaspi caerulescens using ${ }^{113} \mathrm{Cd}-\mathrm{NMR}$. Planta 221: 928-936.

Ueno, D., Milner, M. J., Yamaji, N., Yokosho, K., Koyama, E., Clemencia Zambrano, M., Kaskie, M., Ebbs, S., Kochian, L. V. and Ma, J. F. 2011b. Elevated expression of TcHMA3 plays a key role in the extreme Cd tolerance in a Cd-hyperaccumulating ecotype of Thlaspi caerulescens. Plant J. 66: 852-862.

Ueno, D., Sasaki, A., Yamaji, N., Miyaji, T., Fujii, Y., Takemoto, Y., Moriyama, S., Che, J., Moriyama, Y., Iwasaki, K. and Ma, J. F. 2015. A polarly localized transporter for efficient manganese uptake in rice. Nature Plants 1: 15170. 
2072

2073

2074

2075

2076

2077

2078

2079

2080

2081

2082

2083

2084

2085

2086

2087

2088

2089

2090

2091

2092

2093

2094

2095

2096

Ueno, D., Yamaji, N., Kono, I., Huang, C. F., Ando, T., Yano, M. and Ma, J. F. 2010. Gene limiting cadmium accumulation in rice. Proc. Natl. Acad. Sci. 107: 16500-16505.

Uraguchi, S., Kamiya, T., Clemens, S. and Fujiwara, T. 2014. Characterization of OsLCT1, a cadmium transporter from indica rice (Oryza sativa). Physiol. Plant. 151: 339-347.

Uraguchi, S., Kamiya, T., Sakamoto, T., Kasai, K., Sato, Y., Nagamura, Y., Yoshida, A., Kyozuka, J., Ishikawa, S. and Fujiwara, T. 2011. Low-affinity cation transporter (OsLCT1) regulates cadmium transport into rice grains. Proc. Natl. Acad. Sci. 108: 20959-20964.

Uraguchi, S., Kiyono, M., Sakamoto, T., Watanabe, I. and Kuno, K. 2009a. Contributions of apoplasmic cadmium accumulation, antioxidative enzymes and induction of phytochelatins in cadmium tolerance of the cadmium-accumulating cultivar of black oat (Avena strigosa Schreb.). Planta 230: 267-276.

Uraguchi, S., Mori, S., Kuramata, M., Kawasaki, A., Arao, T. and Ishikawa, S. 2009b. Rootto-shoot $\mathrm{Cd}$ translocation via the xylem is the major process determining shoot and grain cadmium accumulation in rice. J. Exp. Bot. 60: 2677-2688.

Vaculík, M., Landberg, T., Greger, M., Luxová, M., Stoláriková, M. and Lux, A. 2012. Silicon modifies root anatomy, and uptake and subcellular distribution of cadmium in young maize plants. Ann. Bot. 110: 433-443.

Vaculík, M., Lux, A., Luxová, M., Tanimoto, E. and Lichtscheidl, I. 2009. Silicon mitigates cadmium inhibitory effects in young maize plants. Environ. Exp. Bot. 67: 52-58.

Van Belleghem, F., Cuypers, A., Semane, B., Smeets, K., Vangronsveld, J., d'Haen, J. and Valcke, R. 2007. Subcellular localization of cadmium in roots and leaves of Arabidopsis thaliana. New Phytol. 173: 495-508.

van de Mortel, J. E., Almar Villanueva, L., Schat, H., Kwekkeboom, J., Coughlan, S., Moerland, P. D., Ver Loren van Themaat, E., Koornneef, M. and Aarts, M. G. M. 

2006. Large expression differences in genes for iron and zinc homeostasis, stress response, and lignin biosynthesis distinguish roots of Arabidopsis thaliana and the related metal hyperaccumulator Thlaspi caerulescens. Plant Physiol. 142: 1127-1147.

van der Ent, A., Baker, A. J. M., Reeves, R. D., Pollard, A. J. and Schat, H. 2013. Hyperaccumulators of metal and metalloid trace elements: Facts and fiction. Plant Soil 362: 319-334.

Van der Vliet, L., Peterson, C. and Hale, B. 2007. Cd accumulation in roots and shoots of durum wheat: the roles of transpiration rate and apoplastic bypass. J. Exp. Bot. 58: 2939-2947.

van Hoof, N. A. L. M., Hassinen, V. H., Hakvoort, H. W. J., Ballintijn, K. F., Schat, H., Verkleij, J. A. C., Ernst, W. H. O., Karenlampi, S. O. and Tervahauta, A. I. 2001. Enhanced copper tolerance in Silene vulgaris (Moench) Garcke populations from copper mines is associated with increased transcript levels of a $2 b$-type metallothionein gene. Plant Physiol. 126: 1519-1526.

Vatamaniuk, O. K., Mari, S., Lu, Y.-P. and Rea, P. A. 1999. AtPCS1, a phytochelatin synthase from Arabidopsis: Isolation and in vitro reconstitution. Proc. Natl. Acad. Sci. 96: $7110-7115$.

Vatamaniuk, O. K., Mari, S., Lu, Y.-P. and Rea, P. A. 2000. Mechanism of heavy metal ion activation of phytochelatin (PC) synthase blocked thiols are sufficient for PC synthase-catalyzed transpeptidation of glutathione and related thiol peptides. J. Biol. Chem. 275: 31451-31459.

Vazquez, S., Goldsbrough, P. and Carpena, R. O. 2006. Assessing the relative contributions of phytochelatins and the cell wall to cadmium resistance in white lupin. Physiol. Plant. 128: 487-495. 
2121

2122

2123

2124

2125

2126

2127

2128

2129

2130

2131

2132

2133

2134

2135

2136

2137

2138

2139

2140

2141

2142

2143

2144

2145

Verbruggen, N., Hermans, C. and Schat, H. 2009a. Mechanisms to cope with arsenic or cadmium excess in plants. Curr. Opin. Plant Biol. 12: 364-372.

Verbruggen, N., Hermans, C. and Schat, H. 2009b. Molecular mechanisms of metal hyperaccumulation in plants. New Phytol. 181: 759-776.

Verbruggen, N., Juraniec, M., Baliardini, C. and Meyer, C.-L. 2013. Tolerance to cadmium in plants: the special case of hyperaccumulators. BioMetals 26: 633-638.

Verret, F., Gravot, A., Auroy, P., Leonhardt, N., David, P., Nussaume, L., Vavasseur, A. and Richaud, P. 2004. Overexpression of AtHMA4 enhances root-to-shoot translocation of zinc and cadmium and plant metal tolerance. FEBS Lett. 576: 306-312.

Vert, G., Grotz, N., Dédaldéchamp, F., Gaymard, F., Guerinot, M. L., Briat, J.-F. and Curie, C. 2002. IRT1, an Arabidopsis transporter essential for iron uptake from the soil and for plant growth. Plant Cell 14: 1223-1233.

Vieira da Cunha, K. P., Araújo do Nascimento, C. W. and da Silva, A. J. 2008. Silicon alleviates the toxicity of cadmium and zinc for maize (Zea mays L.) grown on a contaminated soil. J. Plant Nutr. Soil Sci. 171: 849-853.

Vogel-Mikuš, K., Arčon, I. and Kodre, A. 2010. Complexation of cadmium in seeds and vegetative tissues of the cadmium hyperaccumulator Thlaspi praecox as studied by Xray absorption spectroscopy. Plant Soil 331: 439-451.

Vogel-Mikus, K., Pongrac, P., Kump, P., Necemer, M., Simcic, J., Pelicon, P., Budnar, M., Povh, B. and Regvar, M. 2007. Localisation and quantification of elements within seeds of $\mathrm{Cd} / \mathrm{Zn}$ hyperaccumulator Thlaspi praecox by micro-PIXE. Environ. Pollut. 147: 50-59.

Vogel-Mikus, K., Regvar, M., Mesjasz-Przybylowicz, J., Przybylowicz, W. J., Simcic, J., Pelicon, P. and Budnar, M. 2008. Spatial distribution of cadmium in leaves of metal hyperaccumulating Thlaspi praecox using micro-PIXE. New Phytol. 179: 712-721. 
Vögeli-Lange, R. and Wagner, G. J. 1990. Subcellular localization of cadmium and cadmiumbinding peptides in tobacco leaves. Implication of a transport function for cadmiumbinding peptides. Plant Physiol. 92: 1086-1093.

Vollenweider, P., Cosio, C., Gunthardt-Goerg, M. S. and Keller, C. 2006. Localization and effects of cadmium in leaves of a cadmium-tolerant willow (Salix viminalis L.): Part II Microlocalization and cellular effects of cadmium. Environ. Exp. Bot. 58: 25-40.

von Wirén, N., Marschner, H. and Römheld, V. 1996. Roots of iron-efficient maize also absorb phytosiderophore-chelated zinc. Plant Physiol. 111: 1119-1125.

Wang, J., Su, L., Yang, J., Yuan, J., Yin, A., Qiu, Q., Zhang, K. and Yang, Z. $2015 a$. Comparisons of cadmium subcellular distribution and chemical forms between low-Cd and high-Cd accumulation genotypes of watercress (Nasturtium officinale L. R. Br.). Plant Soil 396: 325-337.

Wang, P., De Schamphelaere, K. A. C., Kopittke, P. M., Zhou, D.-M., Peijnenburg, W. J. G. M. and Lock, K. 2012. Development of an electrostatic model predicting copper toxicity to plants. J. Exp. Bot. 63: 659-668.

Wang, P., Deng, X., Huang, Y., Fang, X., Zhang, J., Wan, H. and Yang, C. $2015 b$. Comparison of subcellular distribution and chemical forms of cadmium among four soybean cultivars at young seedlings. Environ. Sci. Pollut. Res. 22: 19584-19595.

Wang, P., Kinraide, T. B., Zhou, D., Kopittke, P. M. and Peijnenburg, W. J. G. M. 2011. Plasma membrane surface potential: dual effects upon ion uptake and toxicity. Plant Physiol. 155: 808-820.

Wang, P., Zhou, D., Luo, X. and Li, L. 2009. Effects of Zn-complexes on zinc uptake by wheat (Triticum aestivum) roots: a comprehensive consideration of physical, chemical and biological processes on biouptake. Plant Soil 316: 177-192. 
Wang, S., Wang, F. and Gao, S. 2015c. Foliar application with nano-silicon alleviates Cd toxicity in rice seedlings. Environ. Sci. Pollut. Res. 22: 2837-2845.

Wang, Y., Wang, C., Liu, Y., Yu, K. and Zhou, Y. 2018. GmHMA3 sequesters Cd to the root endoplasmic reticulum to limit translocation to the stems in soybean. Plant Sci. 270: 23-29.

Weggler, K., McLaughlin, M. J. and Graham, R. D. 2004. Effect of chloride in soil solution on the plant availability of biosolid-borne cadmium. J. Environ. Quality 33: 496-504.

Wei, S., Anders, I. and Feller, U. 2014. Selective uptake, distribution, and redistribution of $109 \mathrm{Cd}, 57 \mathrm{Co}, 65 \mathrm{Zn}, 63 \mathrm{Ni}$, and $134 \mathrm{Cs}$ via xylem and phloem in the heavy metal hyperaccumulator Solanum nigrum L. Environ. Sci. Pollut. Res. 21: 7624-7630.

Wei, S., Zhou, Q. and Koval, P. V. 2006. Flowering stage characteristics of cadmium hyperaccumulator Solanum nigrum L. and their significance to phytoremediation. Sc. Total Environ. 369: 441-446.

Wei, Z. G., Wong, J. W. C., Zhao, H. Y., Zhang, H. J., Li, H. X. and Hu, F. 2007. Separation and determination of heavy metals associated with low molecular weight chelators in xylem saps of Indian mustard (Brassica juncea) by size exclusion chromatography and atomic absorption spectrometry. Biol. Trace Element Res. 118: 146-158.

Welch, R. M. and Norvell, W. A. 1999. Mechanisms of cadmium uptake, translocation and deposition in plants. In: McLaughlin, M. J. and Singh, B. R. (eds) Cadmium in soils and plants. Kluwer Academic Publishers, Dordrecht.

Weng, L., Temminghoff, E. J. M., Lofts, S., Tipping, E. and Van Riemsdijk, W. H. 2002. Complexation with dissolved organic matter and solubility control of heavy metals in a sandy soil. Environ. Sci. Technol. 36: 4804-4810.

White, M. C., Chaney, R. L. and Decker, A. M. 1981. Metal complexation in xylem fluid. III. Electrophoretic evidence. Plant Physiol. 67: 311-315. 
White, P. J. 2001. The pathways of calcium movement to the xylem. J. Exp. Bot. 358: 892899.

Wiggenhauser, M., Bigalke, M., Imseng, M., Müller, M., Keller, A., Murphy, K., Kreissig, K., Rehkämper, M., Wilcke, W. and Frossard, E. 2016. Cadmium isotope fractionation in soil-wheat systems. Environ. Sci. Technol. 50: 9223-9231.

Willems, G., Dräger, D. B., Courbot, M., Godé, C., Verbruggen, N. and Saumitou-Laprade, P. 2007. The genetic basis of zinc tolerance in the metallophyte Arabidopsis halleri ssp. halleri (Brassicaceae): An analysis of quantitative trait loci. Genetics 176: 659-674.

Wojas, S., Hennig, J., Plaza, S., Geisler, M., Siemianowski, O., Sklodowska, A., Ruszczynska, A., Bulska, E. and Antosiewicz, D. M. 2009. Ectopic expression of Arabidopsis ABC transporter MRP7 modifies cadmium root-to-shoot transport and accumulation. Environ. Pollut. 157: 2781-2789.

Wójcik, M., Skórzyńska-Polit, E. and Tukiendorf, A. 2006. Organic acids accumulation and antioxidant enzyme activities in Thlaspi caerulescens under $\mathrm{Zn}$ and $\mathrm{Cd}$ stress. Plant Growth Regul. 48: 145-155.

Wojcik, M., Vangronsveld, J., D'Haen, J. and Tukiendorf, A. 2005a. Cadmium tolerance in Thlaspi caerulescens: II. Localization of cadmium in Thlaspi caerulescens. Environ. Exp. Bot. 53: 163-171.

Wojcik, M., Vangronsveld, J. and Tukiendorf, A. 2005b. Cadmium tolerance in Thlaspi caerulescens: I. Growth parameters, metal accumulation and phytochelatin synthesis in response to cadmium. Environ. Exp. Bot. 53: 151-161.

Wong, C. K. E. and Cobbett, C. S. 2009. HMA P-type ATPases are the major mechanism for root-to-shoot Cd translocation in Arabidopsis thaliana. New Phytol. 181: 71-78. 
Wong, C. K. E., Jarvis, R. S., Sherson, S. M. and Cobbett, C. S. 2009. Functional analysis of the heavy metal binding domains of the $\mathrm{Zn} / \mathrm{Cd}$-transporting ATPase, HMA2, in Arabidopsis thaliana. New Phytol. 181: 79-88.

Wu, D., Yamaji, N., Yamane, M., Kashino-Fujii, M., Sato, K. and Ma, J. F. 2016a. The HvNramp5 transporter mediates uptake of cadmium and manganese, but not iron. Plant Physiol. 172: 1899-1910.

Wu, J., Sagervanshi, A. and Mühling, K. H. 2018. Sulfate facilitates cadmium accumulation in leaves of Vicia faba L. at flowering stage. Ecotoxicol. Environ. Safety 156: 375382.

Wu, Q., Shigaki, T., Williams, K. A., Han, J.-S., Kim, C. K., Hirschi, K. D. and Park, S. 2011. Expression of an Arabidopsis $\mathrm{Ca} 2+/ \mathrm{H}+$ antiporter $\mathrm{CAX} 1$ variant in petunia enhances cadmium tolerance and accumulation. J. Plant Physiol. 168: 167-173.

Wu, Q. T. 1989. Biodisponibilité du cadmium dans les systèmes sol-plante. Ecole Nationale Supérieure d'Agronomie et des Industries Alimentaires. Institut National Polytechnique de Lorraine, Vandoeuvre-les-Nancy.

Wu, Z., Wang, F., Liu, S., Du, Y., Li, F., Du, R., Wen, D. and Zhao, J. 2016b. Comparative responses to silicon and selenium in relation to cadmium uptake, compartmentation in roots, and xylem transport in flowering Chinese cabbage (Brassica campestris L. ssp. chinensis var. utilis) under cadmium stress. Environ. Exp. Bot. 131: 173-180.

Xiao, H., Yin, L., Xu, X., Li, T. and Han, Z. 2008. The iron-regulated transporter, MbNRAMP1, isolated from Malus baccata is involved in Fe, Mn and Cd trafficking. Ann. Bot. 102: 881-889.

Xie, H., Jiang, R., Zhang, F., McGrath, S. and Zhao, F. 2009. Effect of nitrogen form on the rhizosphere dynamics and uptake of cadmium and zinc by the hyperaccumulator Thlaspi caerulescens. Plant Soil 318: 205-215. 
Xiong, J., An, L., Lu, H. and Zhu, C. 2009. Exogenous nitric oxide enhances cadmium tolerance of rice by increasing pectin and hemicellulose contents in root cell wall. Planta 230: 755-765.

Xu, S., Lin, S. and Lai, Z. 2015. Cadmium impairs iron homeostasis in Arabidopsis thaliana by increasing the polysaccharide contents and the iron-binding capacity of root cell walls. Plant Soil 392: 71-85.

Yamaguchi, C., Takimoto, Y., Ohkama-Ohtsu, N., Hokura, A., Shinano, T., Nakamura, T., Suyama, A. and Maruyama-Nakashita, A. 2016. Effects of cadmium treatment on the uptake and translocation of sulfate in Arabidopsis thaliana. Plant Cell Physiol. 57: $2353-2366$.

Yamaji, N. and Ma, J. F. 2017. Node-controlled allocation of mineral elements in Poaceae. Curr. Opin. Plant Biol. 39: 18-24.

Yamaji, N., Xia, J., Mitani-Ueno, N., Yokosho, K. and Feng Ma, J. 2013. Preferential delivery of zinc to developing tissues in rice is mediated by P-Type Heavy Metal ATPase OsHMA2. Plant Physiol. 162: 927-939.

Yan, B.-F., Nguyen, C., Pokrovsky, O. S., Candaudap, F., Coriou, C., Bussière, S., Robert, T. and Cornu, J. Y. 2018. Contribution of remobilization to the loading of cadmium in durum wheat grains: impact of post-anthesis nitrogen supply. Plant Soil 424: 591-606.

Yan, J., Wang, P., Wang, P., Yang, M., Lian, X., Tang, Z., Huang, C. F., Salt, D. E. and Zhao, F. J. 2016. A loss-of-function allele of OsHMA3 associated with high cadmium accumulation in shoots and grain of Japonica rice cultivars. Plant Cell Environ. 39: 1941-1954.

Yang, M., Zhang, Y., Zhang, L., Hu, J., Zhang, X., Lu, K., Dong, H., Wang, D., Zhao, F.-J., Huang, C.-F. and Lian, X. 2014. OsNRAMP5 contributes to manganese translocation and distribution in rice shoots. J. Exp. Bot. 65: 4849-4861. 
Yang, X. E., Long, X. X., Ye, H. B., He, Z. L., Calvert, D. V. and Stoffella, P. J. 2004. Cadmium tolerance and hyperaccumulation in a new Zn-hyperaccumulating plant species (Sedum alfredii Hance). Plant Soil 259: 181-189.

Yang, Y., Xiong, J., Chen, R., Fu, G., Chen, T. and Tao, L. 2016. Excessive nitrate enhances cadmium $(\mathrm{Cd})$ uptake by up-regulating the expression of OsIRT1 in rice (Oryza sativa). Environ. Exp. Bot. 122: 141-149.

Yoneyama, T., Gosho, T., Kato, M., Goto, S. and Hayashi, H. 2010. Xylem and phloem transport of $\mathrm{Cd}, \mathrm{Zn}$ and $\mathrm{Fe}$ into the grains of rice plants (Oryza sativa L.) grown in continuously flooded Cd-contaminated soil. Soil Sci. Plant Nutr. 56: 445-453.

Yu, H.-Y., Liu, C., Zhu, J., Li, F., Deng, D.-M., Wang, Q. and Liu, C. 2016. Cadmium availability in rice paddy fields from a mining area: The effects of soil properties highlighting iron fractions and pH value. Environ. Pollut. 209: 38-45.

Zhang, F., Römheld, V. and Marschner, H. 1989. Effect of zinc deficiency in wheat on the release of zinc and iron mobilizing root exudates. Z. Pflanzenernaehrung Bodenkunde 152: $205-210$.

Zhang, L., Wu, J., Tang, Z., Huang, X.-Y., Wang, X., Salt, D. E. and Zhao, F.-J. 2019. Variation in the BrHMA3 coding region controls natural variation in cadmium accumulation in Brassica rapa vegetables. J. Exp. Bot. 70: 5865-5878.

Zhang, X. D., Wang, Y., Li, H. B. and Yang, Z. M. 2018. Isolation and identification of rapeseed (Brassica napus) cultivars for potential higher and lower Cd accumulation. $J$. Plant Nutr. Soil Sci. 181: 479-487.

Zhang, Z.-C., Chen, B.-X. and Qiu, B.-S. 2010. Phytochelatin synthesis plays a similar role in shoots of the cadmium hyperaccumulator Sedum alfredii as in non-resistant plants. Plant Cell Environ. 33: 1248-1255. 
Zhao, F. J., Hamon, R. E. and McLaughlin, M. J. 2001. Root exudates of the hyperaccumulator Thlaspi caerulescens do not enhance metal mobilization. New Phytol. 151: 613-620.

Zhou, H., Zeng, M., Zhou, X., Liao, B.-H., Peng, P.-Q., Hu, M., Zhu, W., Wu, Y.-J. and Zou, Z.-J. 2015. Heavy metal translocation and accumulation in iron plaques and plant tissues for 32 hybrid rice (Oryza sativa L.) cultivars. Plant Soil 386: 317-329.

Zhou, H., Zhu, W., Yang, W.-T., Gu, J.-F., Gao, Z.-X., Chen, L.-W., Du, W.-Q., Zhang, P., Peng, P.-Q. and Liao, B.-H. 2018. Cadmium uptake, accumulation, and remobilization in iron plaque and rice tissues at different growth stages. Ecotoxicol. Environ. Safety 152: 91-97.

Zimeri, A. M., Dhankher, O. P., McCaig, B. and Meagher, R. B. 2005. The plant MT1 metallothioneins are stabilized by binding cadmiums and are required for cadmium tolerance and accumulation. Plant Mol. Biol. 58: 839-855. 


\section{Figure captions}

2310

2311

2312

2313

2314

Figure 1. Principal reactions and processes controlling cadmium availability at the root-soil interface. PM: Plasma membrane; Ls: Organic ligand originating from the soil; Lp: organic ligand originating from rhizodeposition. For simplification, the cell wall is not represented.

Figure 2. Schematic representation of Arabidopsis thaliana root with the gene/proteins involved in Cd transport. For simplification, the cell wall is not represented.

Figure 3. Schematic representation of a rice (Oryza sativa) root with the gene/proteins involved in Cd transport. For simplification, the cell wall is not represented. Question mark after a protein name means it might not be expressed in the tissue, although it has been found in rice roots.

Figure 4. Schematic representation of Noccaea caerulescens root with the gene/proteins involved in Cd transport. For simplification, the cell wall is not represented.

Figure 5. Schematic representation of leaf tissues with the transporters involved in Cd distribution. The prefix before the gene name indicates the plant species in which it was observed. Nc: Noccaea caerulescens, Os: Oryza sativa. No prefix means that the gene/transport protein has been observed in several plant species. For simplification, the cell wall is not represented. 
2331 Table 1. Genes involved in $\mathrm{Cd}$ accumulation in plants.

\begin{tabular}{|c|c|c|c|c|c|c|c|}
\hline Function & Name & Annotation & $\begin{array}{l}\text { Organ of } \\
\text { expression }\end{array}$ & Plant species & $\begin{array}{l}\text { Co- } \\
\text { transported }\end{array}$ & $\begin{array}{l}\text { Factor of } \\
\text { upregulation }\end{array}$ & References \\
\hline \multirow[t]{7}{*}{$\begin{array}{l}\text { Uptake } \\
\text { into cell }\end{array}$} & IRT1 & ZIP family & Roots & $\begin{array}{l}\text { Pisum sativum, } \\
\text { Arabidopsis } \\
\text { thaliana, Hordeum } \\
\text { vulgare, Oryza } \\
\text { sativa }\end{array}$ & $\begin{array}{l}\mathrm{Co}^{2+}, \mathrm{Fe}^{2+}, \\
\mathrm{Fe}^{3+}, \mathrm{Mn}^{2+} \\
\mathrm{Zn}^{2+}\end{array}$ & Fe deficiency & $\begin{array}{l}\text { Cohen et al. (1998); } \\
\text { Korshunova et al. } \\
\text { (1999); Nakanishi et al. } \\
\text { (2006); Pedas et al. } \\
\text { (2008); Barberon et al. } \\
\text { (2014) }\end{array}$ \\
\hline & IRT2 & & Roots & O. sativa & $\mathrm{Fe}^{2+}$ & Fe deficiency & Nakanishi et al. (2006) \\
\hline & ZNT1 & & Roots, shoot & $\begin{array}{l}\text { Noccaea } \\
\text { caerulescens }\end{array}$ & $\mathrm{Zn}^{2+}$ & Zn deficiency & $\begin{array}{l}\text { Pence et al. (2000); } \\
\text { Milner et al. }(2012) \text {; } \\
\text { Lin et al. }(2016 \mathrm{a})\end{array}$ \\
\hline & NRAMP1 & $\begin{array}{l}\text { natural } \\
\text { resistance- } \\
\text { associated } \\
\text { macrophage } \\
\text { protein }\end{array}$ & $\begin{array}{l}\text { Roots(+), } \\
\operatorname{shoot}(-)\end{array}$ & $\begin{array}{l}\text { A. thalianal, } O \text {. } \\
\text { sativa, Malus } \\
\text { baccata }\end{array}$ & Fe, $\mathrm{Mn}$ & $\begin{array}{l}\text { Fe and Mn } \\
\text { deficiency }\end{array}$ & $\begin{array}{l}\text { Thomine et al. (2000); } \\
\text { Xiao et al. (2008); } \\
\text { Cailliatte et al. (2010); } \\
\text { Takahashi et al. (2011); } \\
\text { Ishimaru et al. (2012) }\end{array}$ \\
\hline & NRAMP5 & & Roots & $\begin{array}{l}\text { O. sativa, Triticum } \\
\text { polonicum, } T \text {. } \\
\text { aestivum, Zea mays }\end{array}$ & $\mathrm{Mn}, \mathrm{Fe}, \mathrm{Co}$ & & $\begin{array}{l}\text { Ishimaru et al. (2012); } \\
\text { Sasaki et al. (2012); } \\
\text { Tang et al. (2017); Sui } \\
\text { et al. (2018) }\end{array}$ \\
\hline & GLR3.4 & $\begin{array}{l}\text { glutamate } \\
\text { receptors }\end{array}$ & Roots & O. sativa & $\mathrm{Ca}$ & & Chen et al. (2018b) \\
\hline & ANN4 & annexin & Roots & O. sativa & $\mathrm{Ca}$ & & Chen et al. (2018b) \\
\hline \multirow[t]{2}{*}{$\begin{array}{l}\text { Efflux out } \\
\text { of cell }\end{array}$} & MTP9 & $\begin{array}{l}\text { cation diffusion } \\
\text { facilitator (CDF) }\end{array}$ & $\begin{array}{l}\text { Root } \\
\text { endodermis }\end{array}$ & Cucumis sativus & $\mathrm{Mn}$ & $\begin{array}{l}\text { Mn and } \mathrm{Cd} \\
\text { excess }\end{array}$ & Migocka et al. (2015) \\
\hline & PDR8 & $\begin{array}{l}\text { ATP binding } \\
\text { cassettes (ABC) }\end{array}$ & $\begin{array}{l}\text { Roots }(++) \\
\text { (hair and }\end{array}$ & A. thaliana & $\mathrm{Pb}^{2+}$ & & Kim et al. (2007) \\
\hline
\end{tabular}




\begin{tabular}{|c|c|c|c|c|c|c|c|}
\hline & & & \begin{tabular}{|l} 
epidermis), \\
shoot
\end{tabular} & & & & \\
\hline \multirow[t]{3}{*}{ Chelation } & MTL & MT-like protein & Roots & $\begin{array}{l}\text { Sedum } \\
\text { plumbizincicola }\end{array}$ & & & Peng et al. (2017a) \\
\hline & CDT1 & Cys-rich peptide & $\begin{array}{l}\text { Roots, shoots } \\
\text { (cell surface, } \\
\text { cell wall) } \\
\end{array}$ & $\begin{array}{l}\text { Digitaria ciliaris, } \\
\text { O. sativa }\end{array}$ & & Cd exposure & Kuramata et al. (2009) \\
\hline & CAL1 & $\begin{array}{l}\text { Defensin like } \\
\text { protein }\end{array}$ & Roots & O. sativa & & & Luo et al. (2018) \\
\hline \multirow[t]{8}{*}{$\begin{array}{l}\text { Uptake } \\
\text { into the } \\
\text { vacuole }\end{array}$} & HMA3 & $\begin{array}{l}\text { P type ATPase } \\
\text { family, } \\
\text { subfamily HMA } \\
\text { (for Heavy Metal } \\
\text { Associated) }\end{array}$ & Roots, shoot & $\begin{array}{l}\text { A. thaliana, } O . \\
\text { sativa, } N \text {. } \\
\text { caerulescens, } S . \\
\text { plumbizincicola, } \\
\text { Brassica rapa, } \\
\text { Triticum durum }\end{array}$ & $\mathrm{Co}, \mathrm{Pb}, \mathrm{Zn}$ & & $\begin{array}{l}\text { Morel et al. (2009); } \\
\text { Miyadate et al. (2011); } \\
\text { Ueno et al. (2011a); } \\
\text { Ueno et al. (2011b); } \\
\text { Yan et al. (2016); Liu } \\
\text { et al. (2017); Shao et } \\
\text { al. (2018); Maccaferri } \\
\text { et al. (2019); Sui et al. } \\
\text { (2019); Zhang et al. } \\
\text { (2019) }\end{array}$ \\
\hline & MRP3 & $\begin{array}{l}\text { ATP binding } \\
\text { cassettes }(\mathrm{ABC})\end{array}$ & Roots, shoot & $\begin{array}{l}\text { A. thaliana }{ }^{l}, H \text {. } \\
\text { vulgare }\end{array}$ & & & $\begin{array}{l}\text { Tommasini et al. } \\
\text { (1998); Schneider et al. } \\
\text { (2009) }\end{array}$ \\
\hline & MRP7 & & Roots, shoot & A. thaliana ${ }^{2}$ & & & Wojas et al. (2009) \\
\hline & $\mathrm{ABCC} 1$ & & Roots, shoot & $\begin{array}{l}\text { A. thaliana, } H \text {. } \\
\text { vulgare }\end{array}$ & As & & $\begin{array}{l}\text { Park et al. (2012); Song } \\
\text { et al. (2014) }\end{array}$ \\
\hline & $\mathrm{ABCC} 2$ & & Roots, shoot & $\begin{array}{l}\text { A. thaliana, } H \text {. } \\
\text { vulgare }\end{array}$ & As & & $\begin{array}{l}\text { Park et al. (2012); Song } \\
\text { et al. (2014) }\end{array}$ \\
\hline & ABCC3 & & Roots, shoot & A. thaliana & & Cd exposure & Brunetti et al. (2015) \\
\hline & CAX2 & $\begin{array}{l}\text { CAtion } \\
\text { eXchanger }\end{array}$ & Roots, shoot & A. thaliana $^{2}$ & $\begin{array}{l}\mathrm{Ca}^{2+}, \mathrm{Zn}^{2+}, \\
\mathrm{Mn}^{2+}\end{array}$ & & $\begin{array}{l}\text { Pittman et al. (2004); } \\
\text { Koren'kov et al. (2007) }\end{array}$ \\
\hline & CAX4 & & Roots, shoot & A. thaliana ${ }^{2}$ & $\begin{array}{l}\mathrm{Ca}^{2+}, \mathrm{Zn}^{2+}, \\
\mathrm{Mn}^{2+}\end{array}$ & & Koren'kov et al. (2007) \\
\hline
\end{tabular}




\begin{tabular}{|c|c|c|c|c|c|c|c|}
\hline $\begin{array}{l}\text { Efflux out } \\
\text { of the } \\
\text { vacuole }\end{array}$ & NRAMP3 & $\begin{array}{l}\text { natural } \\
\text { resistance- } \\
\text { associated } \\
\text { macrophage } \\
\text { protein }\end{array}$ & Roots, shoot & $\begin{array}{l}\text { A. thaliana, } N \text {. } \\
\text { caerulescens }\end{array}$ & $\mathrm{Fe}, \mathrm{Mn}$ & Fe deficiency & $\begin{array}{l}\text { Oomen et al. (2009) } \\
\text { Thomine et al. (2000) }\end{array}$ \\
\hline & NRAMP4 & & Roots, shoot & $\begin{array}{l}\text { A. thaliana, } N \text {. } \\
\text { caerulescens }\end{array}$ & Fe, $\mathrm{Mn}, \mathrm{Zn}$ & Fe deficiency & $\begin{array}{l}\text { Oomen et al. (2009) } \\
\text { Thomine et al. (2000) }\end{array}$ \\
\hline \multirow[t]{3}{*}{$\begin{array}{l}\text { Xylem } \\
\text { loading }\end{array}$} & HMA2 & $\begin{array}{l}\text { P type ATPase } \\
\text { family, } \\
\text { subfamily HMA } \\
\text { (for Heavy Metal } \\
\text { Associated) }\end{array}$ & $\begin{array}{l}\text { Roots }(++), \\
\text { shoot }\end{array}$ & $\begin{array}{l}\text { A. thaliana, } O \text {. } \\
\text { sativa }\end{array}$ & $\mathrm{Zn}$ & & $\begin{array}{l}\text { Wong and Cobbett } \\
\text { (2009); Wong et al. } \\
(2009) ; \text { Nocito et al. } \\
(2011) ; \text { Satoh- } \\
\text { Nagasawa et al. (2012); } \\
\text { Takahashi et al. (2012); } \\
\text { Yamaji et al. (2013) }\end{array}$ \\
\hline & HMA4 & & $\begin{array}{l}\text { Roots }(++), \\
\text { shoot }\end{array}$ & $\begin{array}{l}\text { A. thaliana, } A \text {. } \\
\text { halleri, } N \text {. } \\
\text { caerulescens }\end{array}$ & $\mathrm{Zn}, \mathrm{Pb}, \mathrm{Cu}$ & $\begin{array}{l}\mathrm{Zn} \text { and } \mathrm{Mn} \\
\text { exposure, } \\
\text { downregulation } \\
\text { by Cd exposure }\end{array}$ & $\begin{array}{l}\text { Papoyan and Kochian } \\
(2004) ; \text { Verret et al. } \\
(2004) ; \text { Mills et al. } \\
(2005) ; \text { Courbot et al. } \\
\text { (2007); Hanikenne et } \\
\text { al. (2008); Ó Lochlainn } \\
\text { et al. (2011); Craciun et } \\
\text { al. (2012) }\end{array}$ \\
\hline & CCX2 & $\begin{array}{l}\text { cation/calcium } \\
\text { (Ca) exchanger }\end{array}$ & $\begin{array}{l}\text { Root, Shoot } \\
(\text { node }++)\end{array}$ & O. sativa & $\mathrm{Ca}$ & & Hao et al. (2018) \\
\hline \multirow[t]{2}{*}{$\begin{array}{l}\text { Phloem } \\
\text { loading }\end{array}$} & LCT1 & $\begin{array}{l}\text { low affinity } \\
\text { cation transporter }\end{array}$ & Shoot & O. sativa & $\begin{array}{l}\mathrm{K}, \mathrm{Mg}, \mathrm{Ca}, \\
\mathrm{Mn}\end{array}$ & & $\begin{array}{l}\text { Uraguchi et al. (2011); } \\
\text { Uraguchi et al. (2014) }\end{array}$ \\
\hline & HMA2 & $\begin{array}{l}\text { P type ATPase } \\
\text { family, } \\
\text { subfamily HMA } \\
\text { (for Heavy Metal } \\
\text { Associated) }\end{array}$ & Shoot (node) & O. sativa & & & Yamaji and Ma (2017) \\
\hline
\end{tabular}


2333

2334 
2335 Figure 1. Principal reactions and processes controlling cadmium availability at the root-soil interface. PM: Plasma membrane; Ls: Organic

2336 ligand originating from the soil; Lp: organic ligand originating from rhizodeposition. For simplification, the cell wall is not represented.

2337

2338

CYTOSOL PM SOIL SOLUTION

SOIL SOLID PHASE

2339

2340

2341

2342
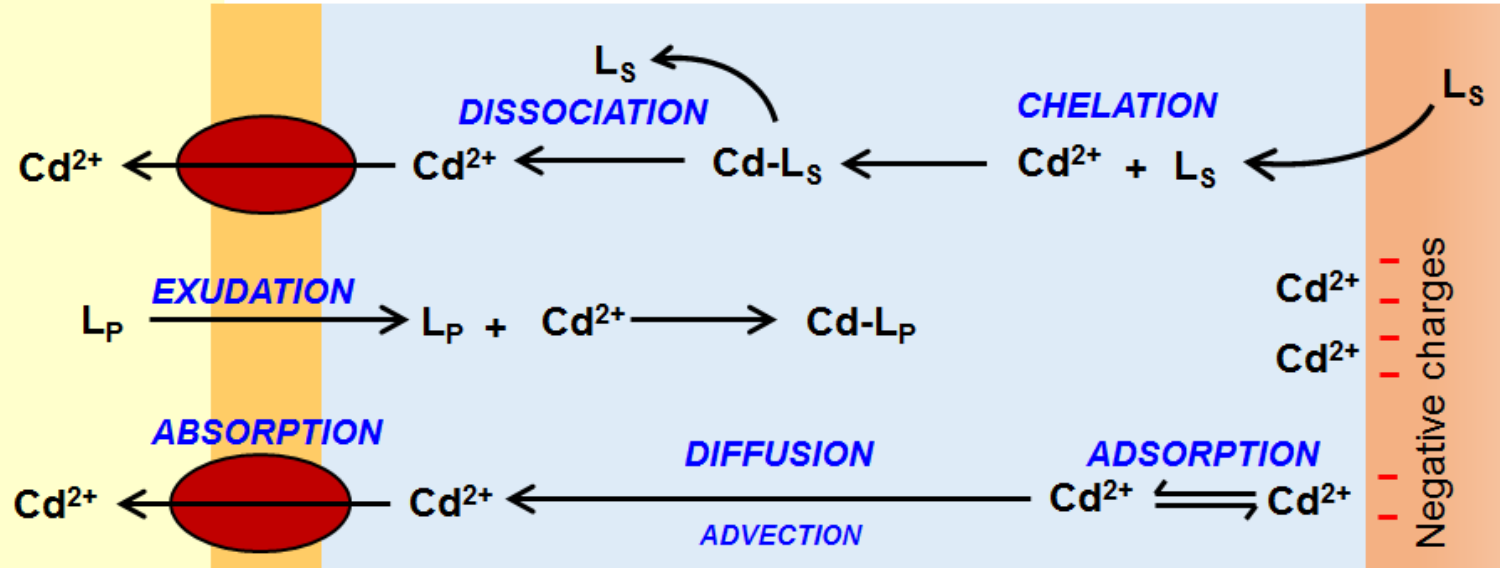

2343

2344

2345

2346

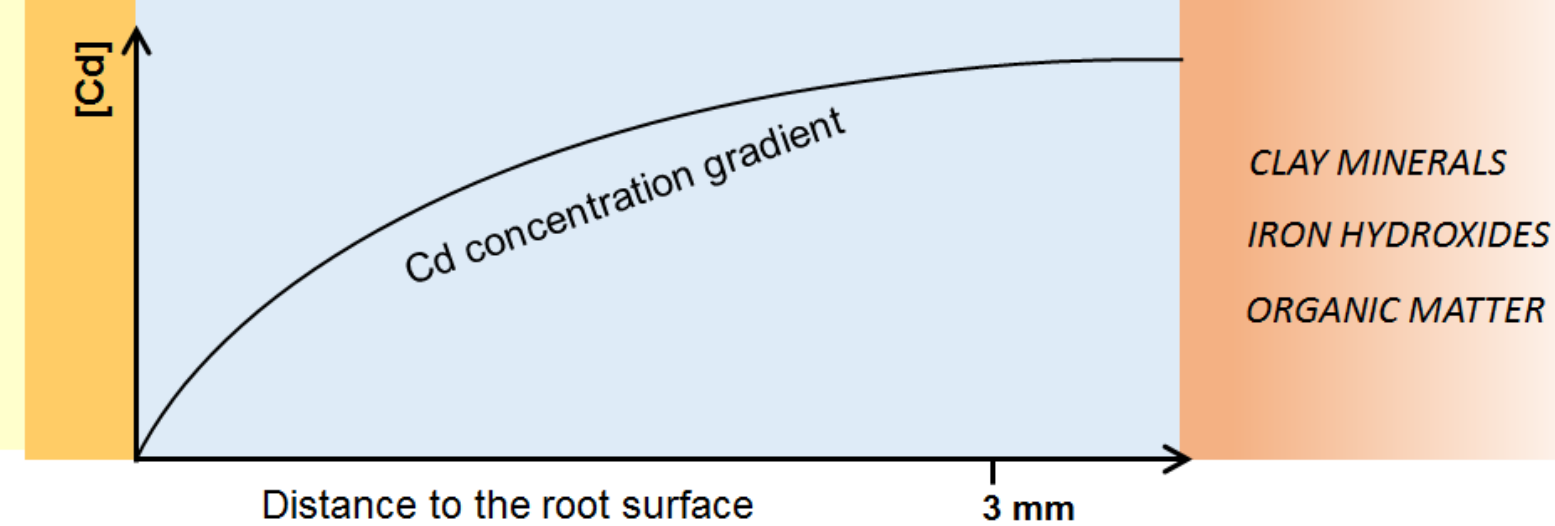


2348

2349

2350

2351

2352

2353

2354

2355

2356

2357

2358
Figure 2. Schematic representation of Arabidopsis thaliana root with the gene/proteins involved in Cd transport. For simplification, the cell wall is not represented.

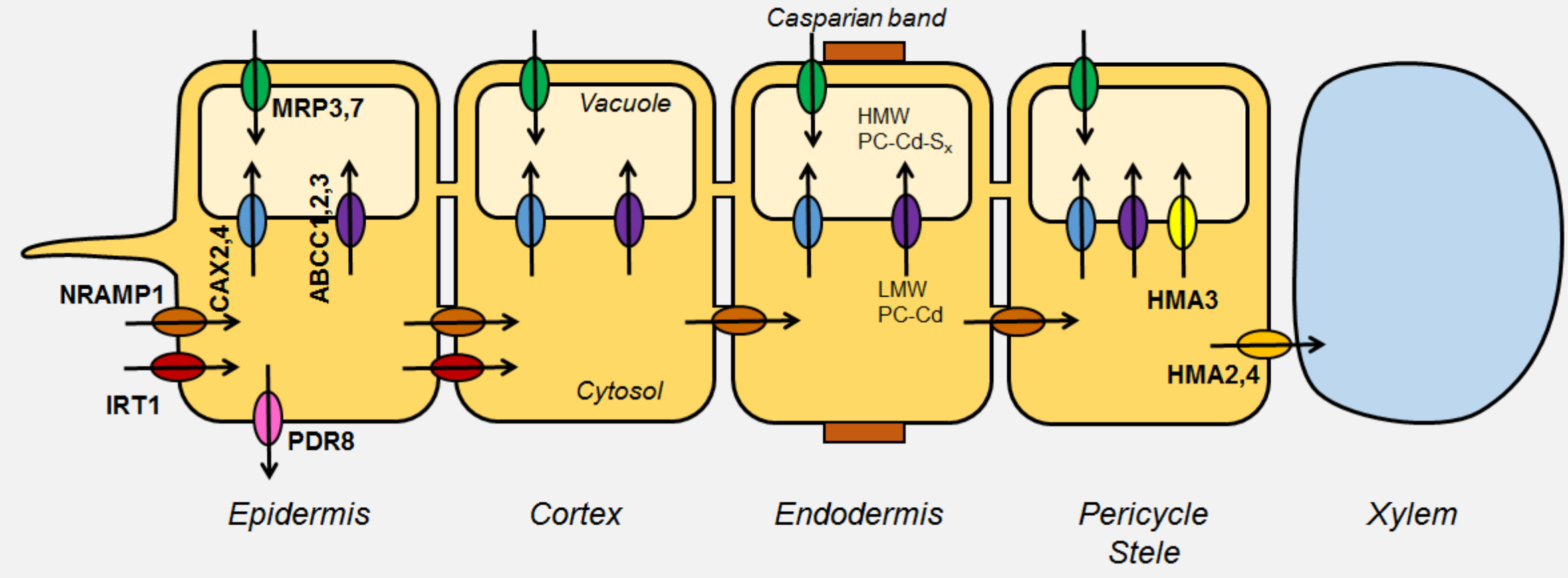


2360

2361

2362

2363

2364

2365

2366

2367

2368

2369

2370

2371

Figure 3. Schematic representation of a rice (Oryza sativa) root with the gene/proteins involved in Cd transport. For simplification, the cell wall

is not represented. A question mark after a protein name means it might not be expressed in the tissue, although it has been found in rice roots.

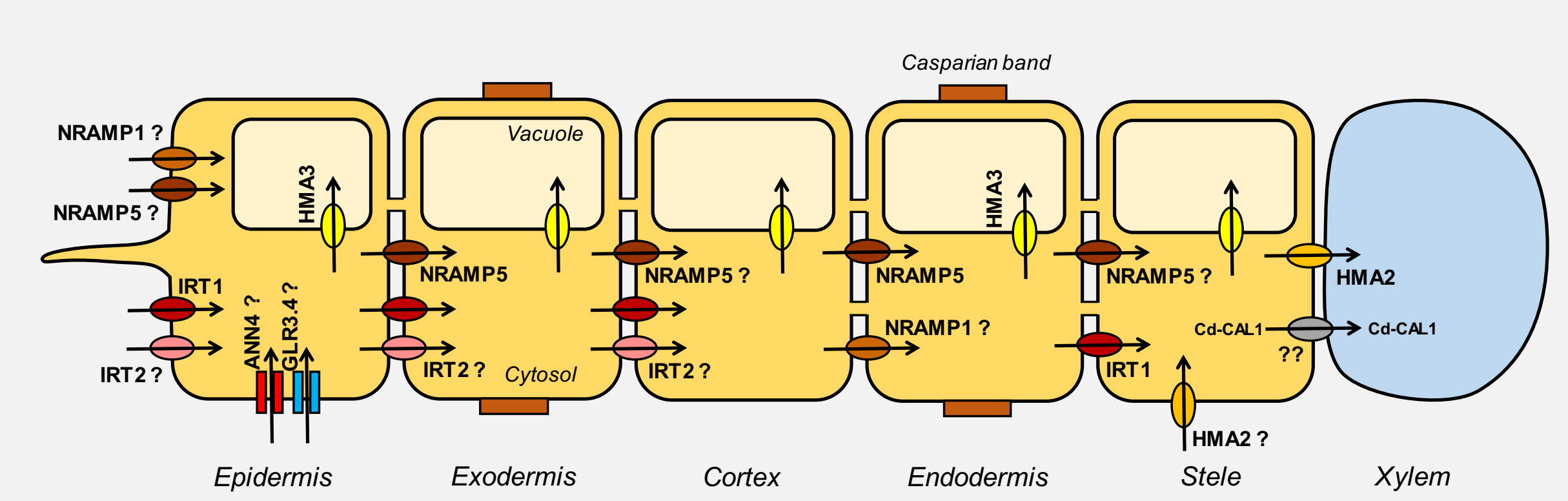


2372 Figure 4. Schematic representation of the hyperaccumulator Noccaea caerulescens root with the gene/proteins involved in Cd transport. For

2373 simplification, the cell wall is not represented.

2374

2375

2377

2378

2379

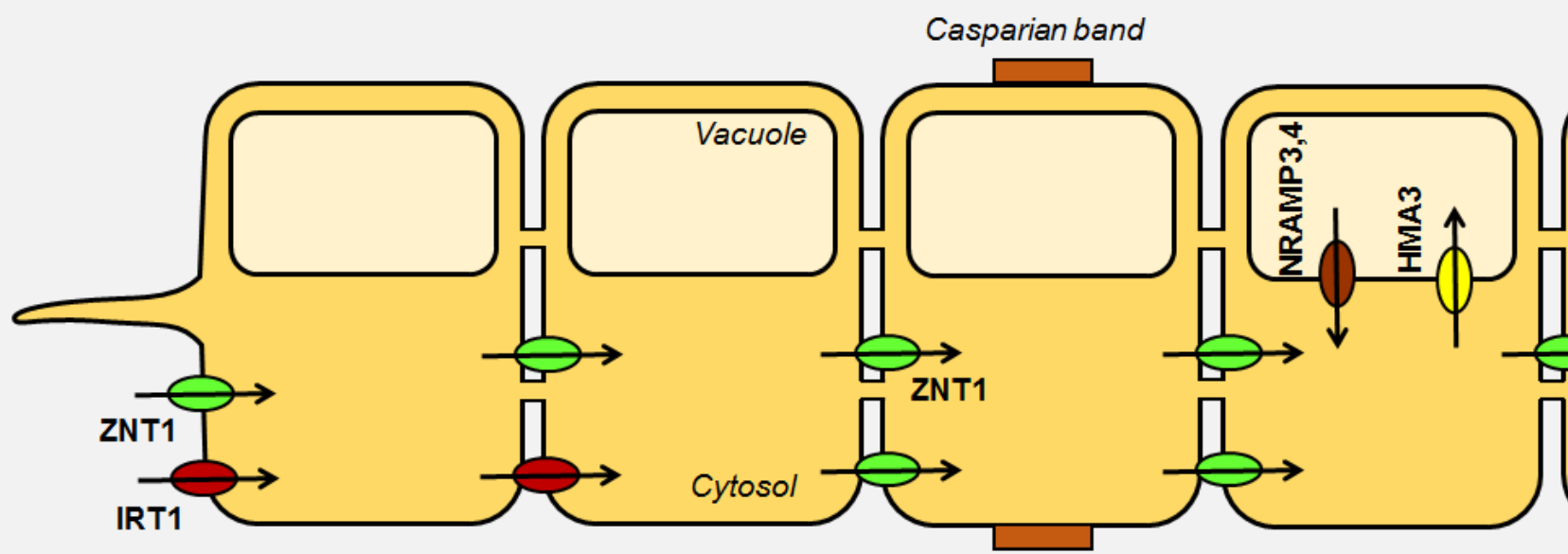

2380

Epidermis

Cortex

Endodermis

Pericycle

Stele

Xylem

2381 
2383

2384

2385

2386

2387

2388

2389

2390

2391

2392

2393

2394
Figure 5. Schematic representation of leaf tissues with the transporters involved in Cd distribution. The prefix before the gene name indicates the plant species in which it was observed. Nc: Noccaea caerulescens, Os: Oryza sativa. No prefix means that the gene/transport protein has been observed in several plant species. For simplification, the cell wall is not represented.

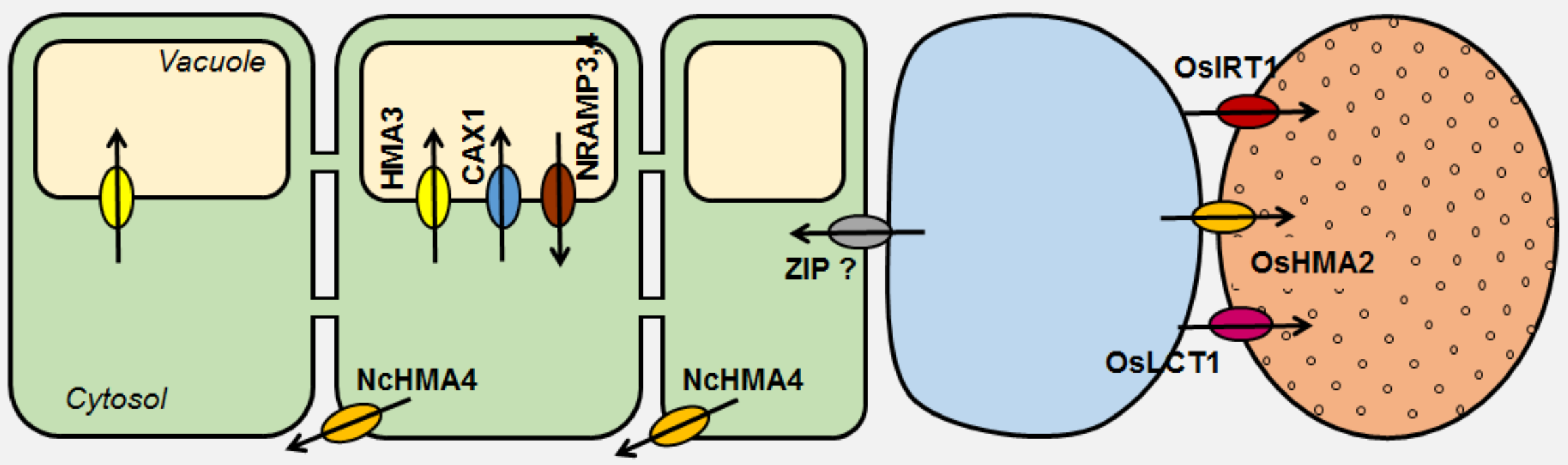

\section{Epidermis}

Mesophyll

Bundle

Xylem

Phloem sheath 